\title{
Evaluation of Lake Simcoe Watershed Rainfall Characteristics
}

\author{
by \\ Rabi C Gautam, B. Tech. Civil Engineering \\ University of Calicut, India 1994
}

\begin{abstract}
A Project
presented to Ryerson University

in partial fulfillment of the

requirements for the degree of

Master of Engineering

in the program of Civil Engineering
\end{abstract}

Toronto, Ontario, Canada

(C) Rabi C Gautam, 2011

PROPERTY OF

AYERSON UNIVERSITY LIBRARY 


\section{Author's Declaration}

I hereby declare that I am the sole author of this project.

I authorize Ryerson University to lend this project to other institutions or individuals for the purpose of scholarly research.

\section{Rabi C Gautam}

I further authorize Ryerson University to reproduce this project by photocopying or by other means, in total or in part, at the request of other institutions or individuals for the purpose of scholarly research.

Rabi CEautam 
Evaluation of Lake Simcoe Watershed Rainfall Characteristics

Master of Engineering 2011, Rabi C Gautam

Civil Engineering, Ryerson University

\begin{abstract}
Lake Simcoe Region Conservation Authority is monitoring the phosphorous loading in Lake Simcoe and to understand the changes in phosphorous loading due to runoff, it is prudent to characterize the rainfall data of the watershed contributing to Lake Simcoe. In this project, hourly and daily rainfall data from 13 different raingage stations surrounding Lake Simcoe was analyzed to identify event, monthly, seasonal and annual statistics and their trend and thereby to identify the driest and wettest and average annual rainfall. After initial analysis, daily rainfall data from only 4 stations with consistent data for an approximate period of 20 years were chosen for further analysis. The results showed that hydrological year 1995-1996 was the wettest and hydrologic year 1991-1992 was the driest year. Similarly summer season and the month of June were the wettest and winter season and month of February were the driest for the watershed. No significant trend was observed in the yearly and monthly rainfall data while an increasing trend was observed at 3 stations for the winter season.
\end{abstract}




\section{Acknowledgements}

I owe my deepest gratitude to my project supervisor Dr. Darko Joksimovic for selecting me for this project and providing his supervision, guidance and support throughout. His constant directions and encouragements enabled me to fulfill this project. I would also express my deepest gratitude to Dr. James $\mathrm{Li}$, who co-supervised the project and provided guidance and support throughout the work.

I am heartily thankful to Dr. Grace Luk for her support, guidance, suggestions and encouragements throughout my Master's program. I would extend my thanks to Mary Neelands for providing administrative support throughout my program. I'm also indebted to my colleagues at work who supported me and allowed me to take time off for my studies.

Special credit goes to my wife Rachana without whose support it would have been impossible for me to complete this work.

Thank you all for providing your support to make my project and program a success. 


\section{Table of Contents}

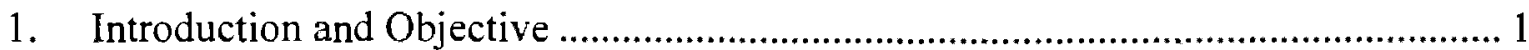

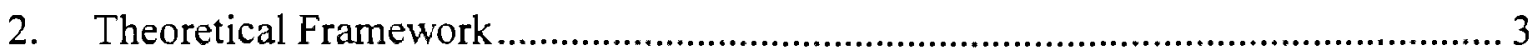

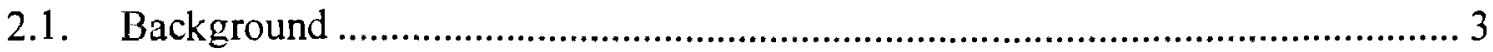

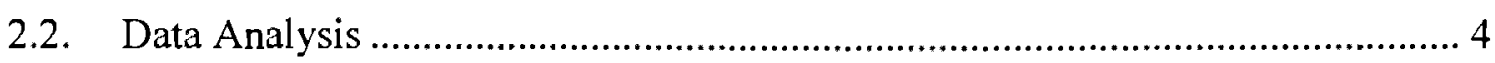

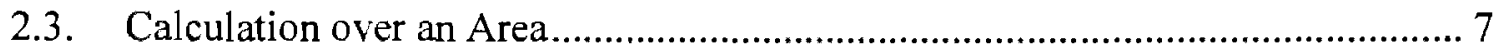

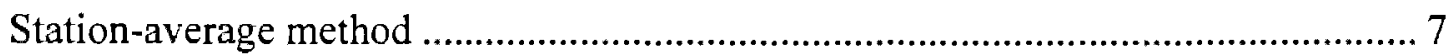

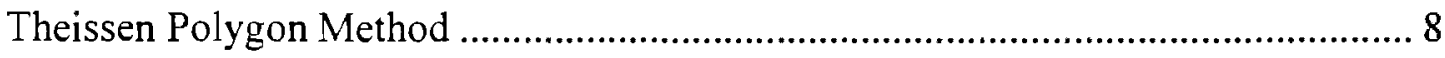

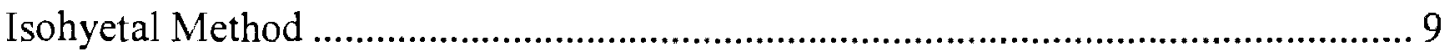

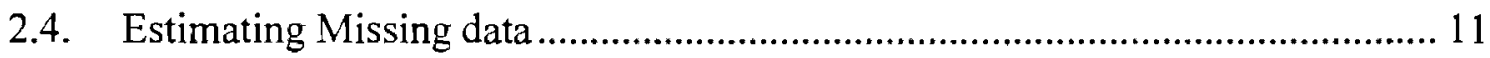

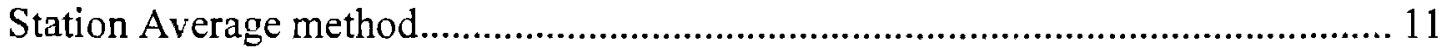

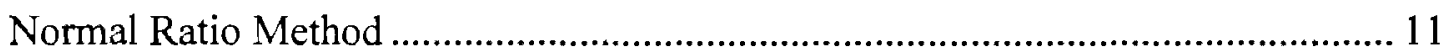

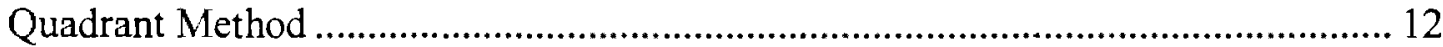

Inverse Distance Weighting Method (IDWM) ....................................................... 13

Kriging estimation method ................................................................................. 14

2.5. Gage Consistency ..................................................................................... 15

2.6. Trend Analysis by Mann-Kendall Test ......................................................... 17

2.7. Previous Similar Studies .............................................................................. 19

3. Data Sources and Summary of Received Data ...................................................... 21

4. Data Analysis and Results .......................................................................................... 30

4.1. Analysis of hourly data ..................................................................................... 30

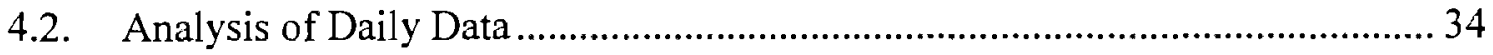

Data Conversion and Filling in Missing data ....................................................... 34

Analysis for Yearly Statistics ........................................................................ 36

Analysis for Seasonal Statistics ................................................................................. 44

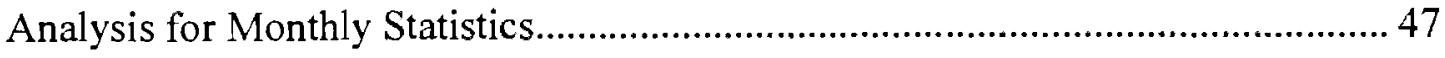

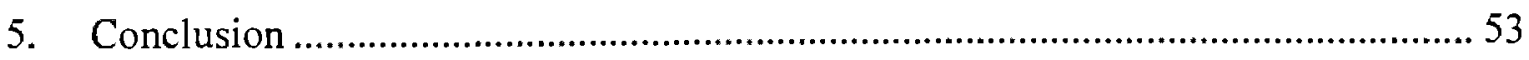




\section{List of Tables}

Table 1 - Minimum density of precipitation network

Table 2 - Number of years of records required for precipitation

Table 3 - Verified daily record of hourly data

Table 4 - Unverified daily record of hourly data

Table 5 - Verified monthly record of daily data

Table 6 - Unverified monthly record of daily data

Table 7 - Summary of received data

Table 8 - Example of data analysis with 12 hour IETD for Egbert station for the year 1997

Table 9 - Example of calculation of event statistics with 12 hour IETD for Egbert station

Table 10 - Summary of received verified monthly records of daily data

Table 11 - Summary of yearly rainfall data

Table 12 - Ranking of Yearly rainfall data

Table 13 - Result of Mann-Kendall test on yearly rainfall data

Table 14 - Summary of seasonal rainfall data

Table15 - Ranking of seasonal rainfall data

Table 16 - Result of Mann-Kendall test on seasonal rainfall data

Table 17 - Summary of monthly data

Table 18 - Ranking of monthly rainfall data

Table 19 - Result of Mann-Kendall test on monthly rainfall data 


\section{$\underline{\text { List of Figures }}$}

Fig 1 - Presentation of yearly data with moving averages

Fig 2 - Graphical representation of IETD

Fig 3 - An example of Theissen Polygon diagram

Fig 4-An example of isohyetal map

Fig 5 - An example of Quadrant

Fig 6 - Double Mass Curve

Fig 7 - Location of raingage stations

Fig 8 - Graphical representation of received data

Fig 9 - Hydrological yearly rainfall data

Fig 10 - Yearly rainfall data with mean annual rainfall

Fig 11 - Graphical presentation of Mann-Kendall test, Coldwater Warminster

Fig 12 - Graphical presentation of Mann-Kendall test, Shanty Bay

Fig 13 - Graphical presentation of Mann-Kendall test, Udora

Fig 14 - Graphical presentation of Mann-Kendall test, Barrie WPCC

Fig 15 - Seasonal Rainfall Data

Fig 16-Monthly rainfall data

\section{$\underline{\text { Appendices }}$}

Appendix A - Excel VBA Program for analysis of 24 hour Inter-event time definition Appendix B - Verified Daily Rainfall Arranged per Hydrological Year Appendix C - Verified Daily Rainfall Arranged per Hydrological Year Appendix D - Verified Daily Rainfall Arranged per Hydrological Year 


\section{Introduction and Objective}

Analysis and characterization of rainfall data is fundamental to the rainfall-runoff process. Runoff is primarily generated by rainstorms. Rainfall characteristics including, quantity, intensity, duration of rainfall is identified by analyzing available rainfall data. Rainfall data have been collected in many regions for a long period of time and are readily available. The analysis of these data is of importance not only for storm water management and design of runoff conveyance but also to establish a relationship of runoff with the source of water pollution of the receiving water body.

Phosphorous loading in the lakes has been identified as one of the problems for the health of the lakes. Lake Simcoe Region Conservation Authority is monitoring the phosphorous loading in Lake Simcoe. Lake Simcoe is located in south central Ontario and covers a surface area of $722 \mathrm{sq} . \mathrm{Km}$. [1].

Climate change has also been a growing area of concern in the health of the lakes. Climate change is a natural process of the climate system. However, the recent changes have been attributed to human activities creating greenhouse gas emissions [2]. The effect of climate change is being translated into changes not only to temperature but also to precipitation pattern. Intergovernmental panel on climate change (IPCC) reports that an increase in the average global temperature creates changes in atmospheric circulation and increases in evaporation and water vapor which is turn changes the pattern of precipitation and atmospheric moisture. IPCC predicts that there will be an increase in global average annual precipitation during the 21 st century but predicts that it varies from region to region. [3]. Ontario Ministry of Natural Resources through its research and modeling predicts that in 2011-2040, almost all of southern Ontario south of a line from Owen Sound to Pembroke will receive up to $10 \%$ less rainfall. [4] This includes the watershed contributing to Lake Simcoe.

To understand the changes in phosphorous loading or any other parameter loading due to runoff; effects of climate change on rainfall pattern etc. it is prudent to characterize the 
rainfall data of the watershed contributing to Lake Simcoe. An effort has been made in this study to analyze the characteristics of rainfall collected from rainfall gage stations that are located on the Lake Simcoe watershed. Data from 13 different raingage stations surrounding Lake Simcoe has been provided for analysis. The primary objective of this study and the report is to

a. analyze the available data and characterize the rainfall to event, monthly, seasonal and annual statistics and their trend, and;

b. identify the driest and wettest and average annual rainfall. 


\section{Theoretical Framework}

\subsection{Background}

Rainfall in general is defined as liquid form of deposition of water from the atmosphere to the surface. Rainfall is the result of condensation of moisture and its aggregation that fall. The following conditions must be fulfilled for rainfall to occur: [5]

- A sufficient supply of moisture, generally in the form of water vapour, must be available in the atmosphere;

- The air containing the water vapour must be cooled to below its condensation point.

- The water vapour must aggregate or condense into water or ice particles.

- These particles must grow to such a size that they fall.

Depending on the size of the drops, liquid precipitation with drop size less than $0.5 \mathrm{~mm}$ diameter are termed as drizzle while those larger than $0.5 \mathrm{~mm}$ is termed as rain [5]. In some weather reports, liquid precipitation due to convective cloud is sometimes distinguished as showers. Showers are generally characterized by short duration and rapid fluctuation of intensity. [6]. Depending on the intensity, rainfall can be termed as slight with accumulation less than $0.5 \mathrm{~mm} / \mathrm{h}$; moderate with accumulation of 0.5 to $4 \mathrm{~mm} / \mathrm{h}$ and heavy for accumulation greater than $4 \mathrm{~mm} / \mathrm{h}$. Similarly showers can be classified as slight for accumulation of about 0 to $2 \mathrm{~mm} / \mathrm{h}$, moderate for accumulation of 2 to $10 \mathrm{~mm} / \mathrm{h}$, heavy for accumulation of 10 to $50 \mathrm{~mm} / \mathrm{h}$ and violent for accumulation of $50 \mathrm{~mm} / \mathrm{h}$. [6].

The other classification of rainfall is based on the mode of lifting mechanism which induces condensation and aggregation of moisture. In general there are three lifting processes: convectional, orographic and cyclonic (frontal) and as such rainfall is classified as convectional, orographic and cyclonic rainfall. [7]. Convectional lifting of the air mass is due to the localized heating of the earth's surface. Orographic lifting occurs when air is blown over mountains. Cyclonic lifting occurs when warm light-air mass collides with and rides up over a heavier cold air mass. 
Traditionally rainfall is measured using raingages which measures the rainfall in just one point. The estimation of rainfall in an area comes from network of raingages. To obtain a reliable estimate of rainfall data from the network of gages it is necessary to establish a suitable network density. Factors including topography, climate, and state of development of the area play a key role in determining the suitable network of raingages. The world meteorological organization in its 1965 publication "Guide to hydrometeorological practices" has established a standard for optimum and minimum networks as given in the following table to serve as a guide. [5]

Table 1: Minimum density of precipitation network

\begin{tabular}{|l|c|c|}
\hline \multicolumn{1}{|c|}{ Type of Region } & $\begin{array}{l}\text { Normal Tolerance } \\
\text { (Area of 1 Station) }\end{array}$ & $\begin{array}{c}\text { Tolerance under Difficulties } \\
\text { (Area for 1 Station) }\end{array}$ \\
\hline $\begin{array}{l}\text { Flat areas of termperate, } \\
\text { Mediterranean and tropical } \\
\text { zones }\end{array}$ & $600-900 \mathrm{sq} . \mathrm{km}$ & $900-3000 \mathrm{sq} . \mathrm{km}$ \\
\hline $\begin{array}{l}\text { Mountainous regions as } \\
\text { bove }\end{array}$ & $100-250 \mathrm{sq} . \mathrm{km}$ & $250-2000 \mathrm{sq} . \mathrm{km}$ \\
\hline $\begin{array}{l}\text { Small mountainous islands } \\
\text { with irregular precipitation }\end{array}$ & $25 \mathrm{sq} . \mathrm{km}$ & \\
\hline Arid and polar zones & $1500-10000 \mathrm{sq} . \mathrm{km}$ & \\
\hline
\end{tabular}

Precipitation is measured in terms of depth. To each precipitation depth corresponds a time period which may be a year, month, day, hour or minute. [5]

\subsection{Data Analysis}

The importance of rainfall/precipitation data in hydrology arises from the fact that in many regions they have been kept for a long period of time and are readily available. Precipitation depths can be converted to stream flows and hydrographs can be derived from it. With the application of appropriate analysis methodology, precipitation can be extrapolated to an extreme or limiting values such as probable maximum precipitation which in turn can be used for flood estimations, design of sewer systems etc. 
Due to the variation of precipitation with time and space, its analysis demands a diversity of techniques. To obtain reliable and stable information from the available data, usually a long period of data is required. The length of data required depends on the variability of the precipitation which in turn depends upon locality and many other meteorological factors, however, $30 \mathrm{yrs}$ is considered a minimum period. [5]. As a guide for the length of data required, Weather Information Branch Report 558 titled 'Studies of length of record needed to obtain satisfactory climatic summaries for various meteorological elements' published by Army Air Forces Headquarters, Washington DC in 1943 specifies the following time period for precipitation data for different areas:

Table 2: Number of years of records required for precipitation

\begin{tabular}{|l|l|l|l|l|l|l|l|l|}
\hline \multirow{2}{*}{$\begin{array}{l}\text { Climatic } \\
\text { Element }\end{array}$} & \multicolumn{3}{|l|}{ Extra Tropical Regions } & \multicolumn{3}{|l|}{ Tropical Regions } \\
\cline { 2 - 9 } & Islands & Coast & Plains & Mountains & Islands & Coast & Plains & Mountains \\
\hline Precipitation & 25 & 30 & 40 & 50 & 30 & 40 & 40 & 50 \\
\hline
\end{tabular}

The analysis of precipitation data requires ordering of precipitation with time. The simplest form of presentation of precipitation data in terms of time is the bar chart in which the total precipitation during a period is plotted as a height and the time of record as the width of the bar chart with equal period as the width.

The simplest form of analysis of precipitation data is to find the average rainfall, either annual or monthly. It is expressed as the arithmetic mean of number of years or months. To minimize the effect of extreme values, median is often used instead of the arithmetic mean.

In order to damp out short term fluctuations and in an attempt to highlight the trend, moving averages are sometimes used. For the moving averages, if the smoothing period chosen is $n$ year, then the $n$ year average $\sum_{1}^{n} P / n$ is plotted at the $(\mathrm{n}+1) / 2$ year and the next year average $\sum_{2}^{n+1} P / n$ is plotted at the $(n+1) / 2+1$ year and so on. In the moving average all the record years do not contribute equally, with the first and the last having 
the least effects an very high and low records affect all the averages into which they are incorporated. However trends occurring over considerable part of the record provide a significant understanding of the data trend.

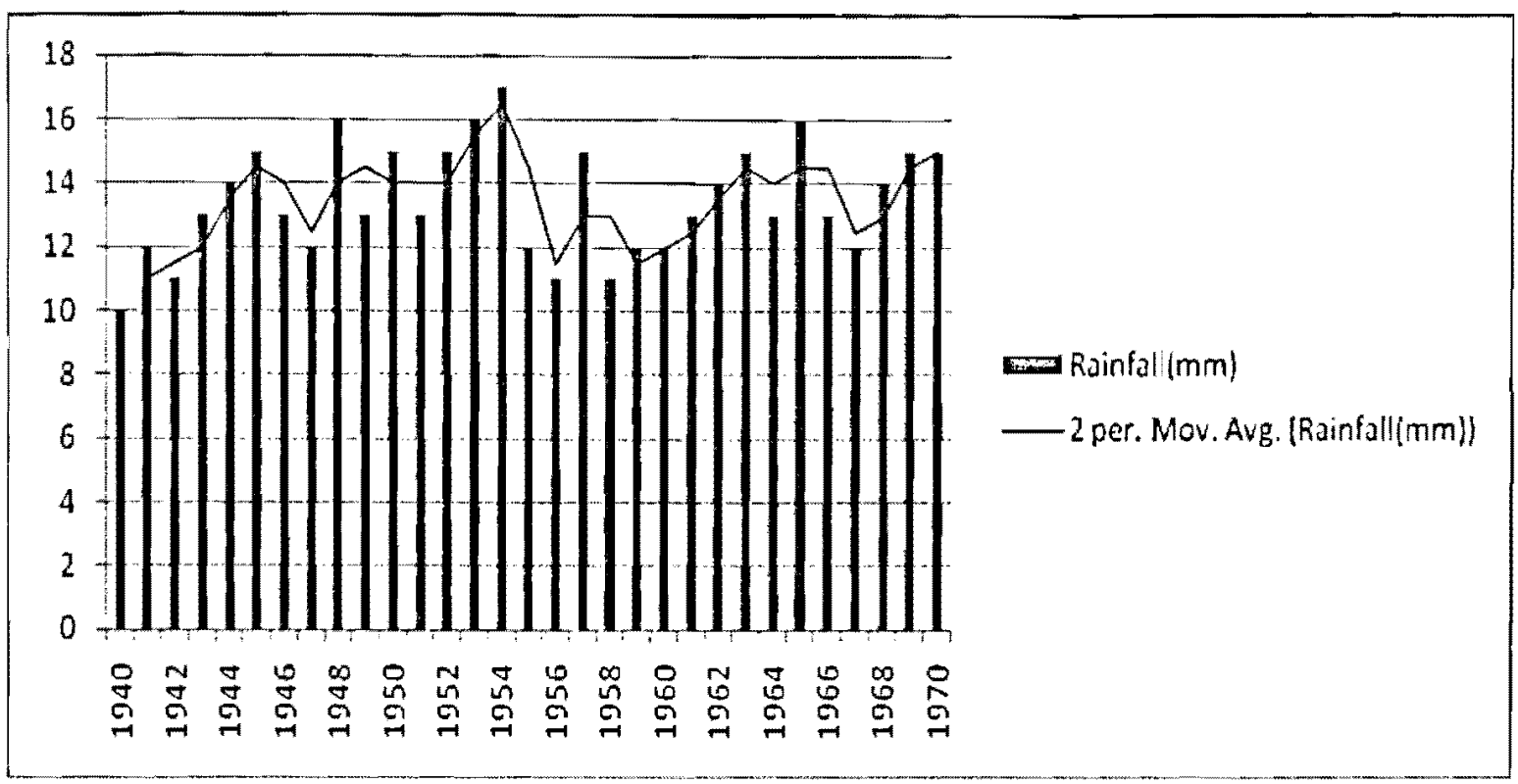

Fig 1: Presentation of Yearly Data with Moving Average

The data can also be analyzed for rainfall events by separating into individual storm events. [8] To isolate an individual storm event from a long range of available data it is required to apply suitable criteria to establish when an event starts and when it ends. A typical way of establishing the criteria for start and end is to identify a minimum period without rainfall also termed as inter event time definition (IETD). Rainfall pulses are separated by the minimum time of no rainfall. If the period of time between the rainfall pulses are greater than the inter event time then the rainfall pulses are categorized as two separate events and if the period of time is shorter than IETD, then the pulses are categorized as a single event[8]. 


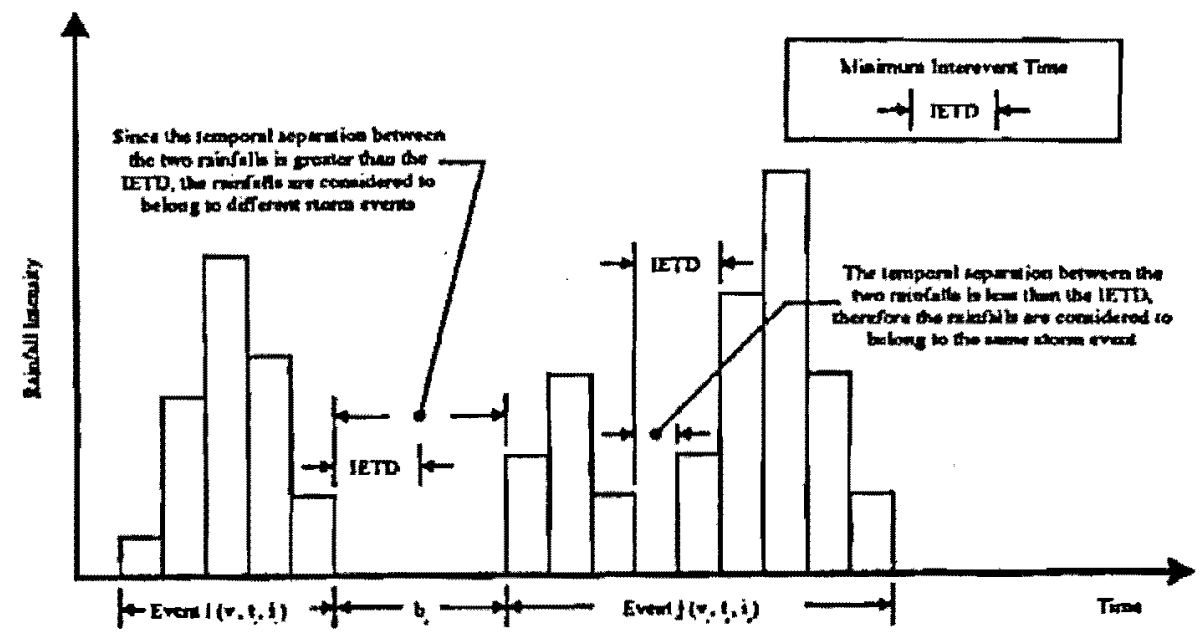

Fig 2: Graphical representation of IETD [8]

The isolated events then can be further statistically analyzed to determine different characteristics within a time period such as annual statistics. Factors such as number of events, average event volume, peak event rainfall, event shape such as standard deviation and skewness, average duration of antecedent period etc. per annum or period can then be determined from such isolated events[9]. From the analyzed data it is then possible to identify a typical year/period and utilize the records for the data for that period for further studies.

\subsection{Calculation over an Area}

Rainfall information collected at raingage stations represents conditions at a particular point. To utilize the data in various hydrological calculations rainfall volume over an area is required and the point data from a network of raingages needs to be transformed into information pertaining to an area. Some of the methods utilized are:

\section{Station-average method}

It is the simplest and most easily used method of estimating areal averages. In this method the each rain gage is given equal weight and average is taken from all the observed values. So the average precipitation over an area is computed as follows [10] 


$$
\mathrm{P}_{\mathrm{avg}}=\sum_{i=1}^{n} P_{\imath} / n
$$

where,

$\mathrm{P}_{\mathrm{i}}=$ precipitation depth at station $\mathrm{i}$

$\mathrm{n}=$ the total number of stations

As this method simply takes an average of all the values without considering any topographical and meteorological condition of the raingage stations and their distribution, the average obtained does not give a true representation of the spatial distribution of the rainfall if the raingages are not uniformly distributed over the entire area. This method will provide reasonably accurate estimate of average rainfall over an area where the raingages are uniformly distributed throughout the area and the rainfall depth over the entire area is more or less constant.

\section{Theissen Polygon Method}

In the situations where the raingages are not uniformly distributed throughout the watershed, Theissen polygon method provides an alternative by assigning areal weightage to the point rainfall data. This method assigns weights to the rain gages according to the proportions of the total watershed area that are geographically closest to each of the raingages [10]. This method, however, does not take into consideration the topography or meteorological factors of the proportional areas. [7]

To draw the theissen polygon lines are first drawn to join the adjoining raingage stations. Perpendicular bisectors are then drawn for each line. The polygon bound by these perpendicular bisectors and the boundary of the watershed represents the area proportional to each stations; eg. in the following figure, area A1, A2, A3, A4 are the proportional areas represented by raingages $\mathrm{S} 1, \mathrm{~S} 2, \mathrm{~S} 3$ and $\mathrm{S} 4$ respectively. 


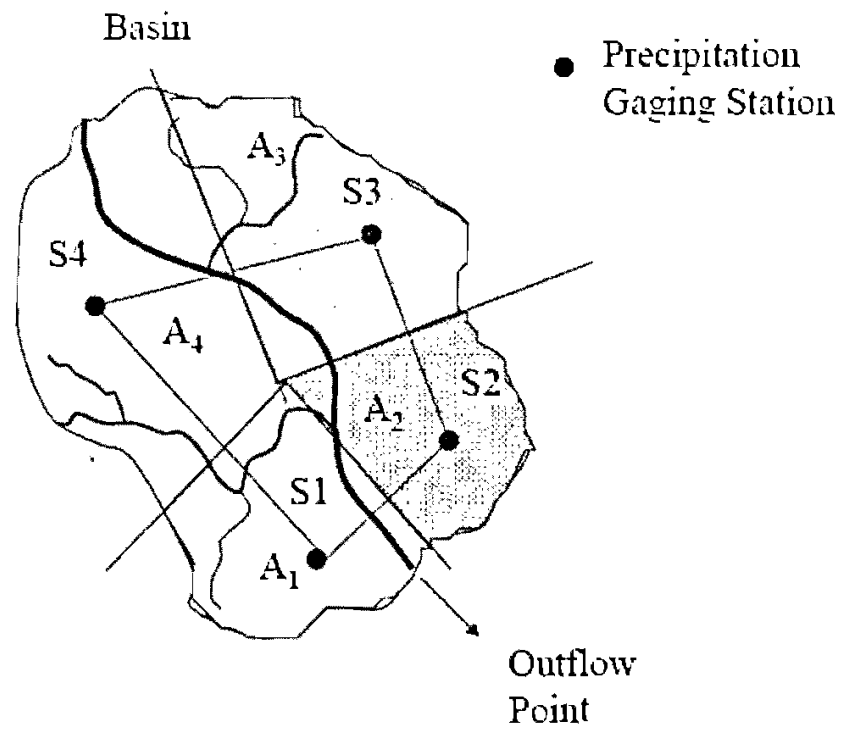

Fig 3. An example of Theissen Polygon diagram

The average precipitation is then determined by the equation [7]

$\mathrm{P}_{\mathrm{avg}}=\sum_{i=1}^{n} P_{i}, A_{i} / \sum_{i=1}^{n} A_{i}$

where,

$\mathrm{P}_{\mathrm{i}}=$ precipitation depth at station $\mathrm{i}$

$\mathrm{n}=$ the total number of stations

$A_{j}=$ Area assigned to station $\mathrm{i}$

\section{Isohyetal Method}

To overcome the shortcoming of non-consideration of topography and meteorological factors in the theissen polygon method, isohyetal method is utilized. Data from the network of raingage stations can be used to construct isohytes ie. lines of equal rainfall depth. Construction of isohyets is subjective and requires great amount of personal knowledge and skill in interpolating data. Considerations for factors such as topography, rainfall pattern, frequency etc. are made while constructing the isohytes. Average 
precipitation between isohytes is calculated as the numerical average of the two adjacent isohytes and the average precipitation of the entire area can be calculated as [7]:

$\mathrm{P}_{\mathrm{avg}}=\sum_{j=1}^{m}\left[\left(P_{j}+P_{j+1}\right)\left(A_{j} / 2\right) / \sum_{j=1}^{m} A_{j}\right.$

where,

$P_{j}=$ precipitation depth at station $\mathrm{j}$

$\mathrm{m}=$ the total number of isohytes

$A_{j}=$ Area between isohyte $j$ and $j+1$

Factors influencing the rainfall catch at each gage can be effectively implemented in this method with experience; however, the accuracy of this method depends on the knowledge and skill of the hydrologist. It is also difficult to accurately delineate the isohytes when the raingage network is not dense enough [11].

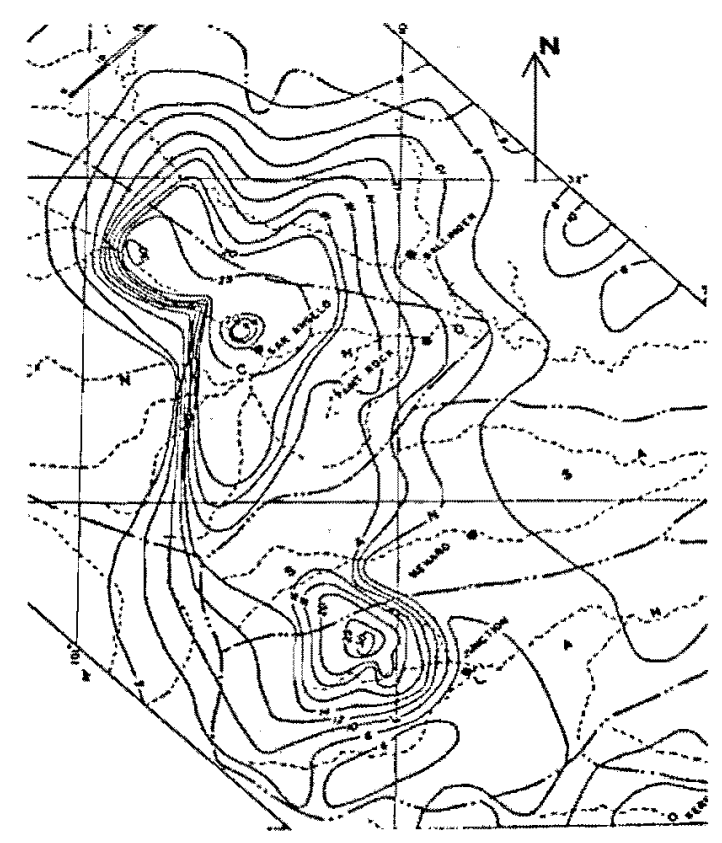

Fig 4: An example of isohyetal map [11] 


\subsection{Estimating Missing data}

Estimation of missing data is one of the most important tasks required in rainfall analysis. Often the problems of missing data are encountered due to various reasons like instrumentation problem or techniques used in measuring the rainfall amounts. Missing data may also be encountered due to systematic errors like water loss during measurements, adhesion loss on the surface of the gage, raindrop splash from the collector etc. Missing data due to these errors are critical as they affect the continuity of rainfall data and which in turn affects the result of analysis carried out on basis of these rainfall as input. [12]

Several methods have been developed to estimate the missing data:

\section{Station Average method}

This method estimates the point average of a station based on the average of surrounding stations in the region. The equation to estimate the missing data is given by [10]:

$\mathrm{P}_{\mathbf{x}}=\sum_{i=1}^{n} P_{i} / n$

where,

$\mathrm{P}_{\mathrm{x}}=$ missing point rainfall at station $\mathrm{x}$

$P_{i}=$ relative point rainfall at station $i$

$\mathrm{n}=$ number of stations

This method gives equal weight to all the catches within the region and estimation by this method may not be accurate if the annual catch at any of the $n$ gages differ from the station of interest by $10 \%$ or more. [10]

\section{Normal Ratio Method}

This method overcomes the shortcoming of giving equal weight to all the raingages. It uses the average annual catch of individual station to derive a weight for the rainfall depth of the station. [10]. 
$\mathrm{P}_{\mathrm{x}}=\sum_{i=1}^{n} w_{i} P_{i}$

$w_{i}=$ weight for the rainfall depth $P_{i}$ at gage $i$ and is calculated as

$\mathrm{w}_{\mathrm{i}}=\mathrm{A}_{\mathrm{x}} / \mathrm{nA}_{\mathrm{i}}$

where

$A_{x}=$ annual average rainfall at station $X$,

$A_{i}=$ annual average rainfall at station $i$

$\mathrm{n}=$ number of stations

\section{Quadrant Method}

Quadrant method is an alternative method to station average and normal-ration method. It also uses the weighted average of gages from other stations within the region. However it does not use all the stations within the region and gives weight to the station based on its distance from the station of concern. This method is based on two assumptions [10]

- Rainfall depth at gages that are located close to each other are not independent estimates of the missing rainfall depth; and,

- The weight assigned to a gage used to estimate the missing value should decrease as the distance between the gage and the point where an estimate is required increases.

To use this method, the region is divided into four quadrants with the origin being the data station with missing information. The surrounding stations are drawn based on their coordinates with respect to the station with missing information and distance from the centre is calculated. Only the stations in each quadrant that is closest to the centre is selected and the weights for those stations are calculated as a function of the reciprocal of the square of the distance between the gage and the centre location. The 
Thus the equation for the weight of station $\mathrm{i}$ is given by [10]

$$
\mathrm{w}_{\mathrm{i}}=\frac{1 / d_{i}^{2}}{\sum_{j=1}^{4}\left(1 / d_{j}^{2}\right)}
$$

where,

$d_{i}=$ distance between gage $i$ and the centre location

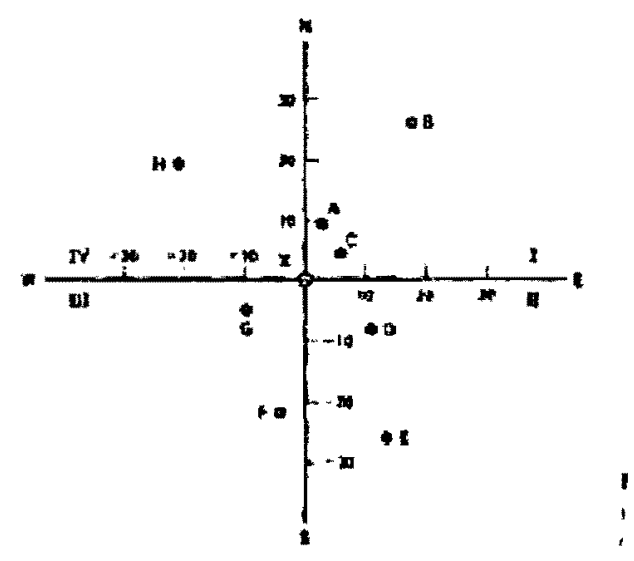

Fig 5: An example of Quadrant

And the equation to find the missing data is again

$\mathrm{P}_{\mathrm{x}}=\sum_{i=1}^{n} w_{i} P_{i}$

\section{Inverse Distance Weighting Method (IDWM]}

It is the most commonly used method for estimation of missing data in rainfall analysis. It is also referred to as national weather service (NWS) method in operational hydrology literatures published in the United States [12] 
It is again the weighting method based on the distance of the neighboring stations to the station with missing data. The equation for the missing data is given by [12]

$$
\mathrm{P}_{\mathrm{x}}=\frac{\sum_{i=1}^{n} P_{i} d_{i x}^{-k}}{\sum_{i=1}^{n} d_{d x}^{-k}}
$$

where,

$\mathrm{P}_{\mathrm{x}}=$ missing data at station $\mathrm{x}$

$\mathrm{P}_{\mathrm{i}}=$ corresponding data at station $\mathrm{i}$

$\mathrm{d}_{\mathrm{ix}}=$ distance between station $\mathrm{i}$ and $\mathrm{x}$

$\mathrm{k}=$ friction distance that ranges from 1 to 6 (most common value 2)

Some of the issues with this method is the choice of weighting factor is arbitrary and the definition of neighboring station is not clear. Several modified IDWM methods have been suggested and tested by Ramesh et al (2005):

- Thiessen polygon approach and inverse distance method

- Coefficient of correlation weighting method

- Inverse exponential weighting method

- Nearest neighbor weighting method

\section{Kriging estimation method}

This is a stochastic interpolation method which is also based on the principle of using the weighted average of surrounding stations to derive a missing value at the station of concern [13]. Ordinary kriging is the most widely used method.

To apply the principle of kriging two tasks are to be performed:

i. Establish the degree of spatial dependence. 
The degree of spatial dependence is established using a semi-variogram model and weights are optimized. Semi-variogram is computed as [14]

Semivariogram $($ distance $h)=0.5 \times$ [average $($ value at location $\mathrm{i}-$ value at location $\mathrm{j})^{2}$ ]

ii. Estimation of missing value

The missing value is then calculated from the equation [12]

$$
\mathrm{P}_{\mathrm{x}}=\sum_{i=1}^{n} \lambda_{i} P_{i}
$$

where,

$\lambda_{i}=$ weight obtained from fitted semi-variogram.

In this method is the observed value is used twice, the first time to estimate the semivariogram and the second time to interpolate the values. [12]

\subsection{Gage Consistency}

Another problem encountered during the analysis of long term rainfall record is the consistency of the data. A consistent data is the data for which the characteristics such as change in observation procedure, exposure of the gauge, change in location etc. is the same throughout the record period of the data [10]. Adjustment to the data needs to be made if the data are inconsistent over a period of time.

The consistency of the data is checked by the method of double mass curve. A double mass curve is a graph of the cumulative rainfall at the rain gage where the data is to be verified for consistency versus the cumulative rainfall of one or more gages in the region that have similar hydro-meteorological condition and are known to be consistent [10]. Double mass curve plotted from consistent data will yield a constant slope. A change in the slope of the double mass curve suggests that the data is inconsistent and adjustment needs to be made. To adjust the data and obtain consistency, the value has to be changed 
to obtain the constant slope of the double mass curve. The values of the double mass curve can be adjusted either at the bottom section or at the top section. [10]

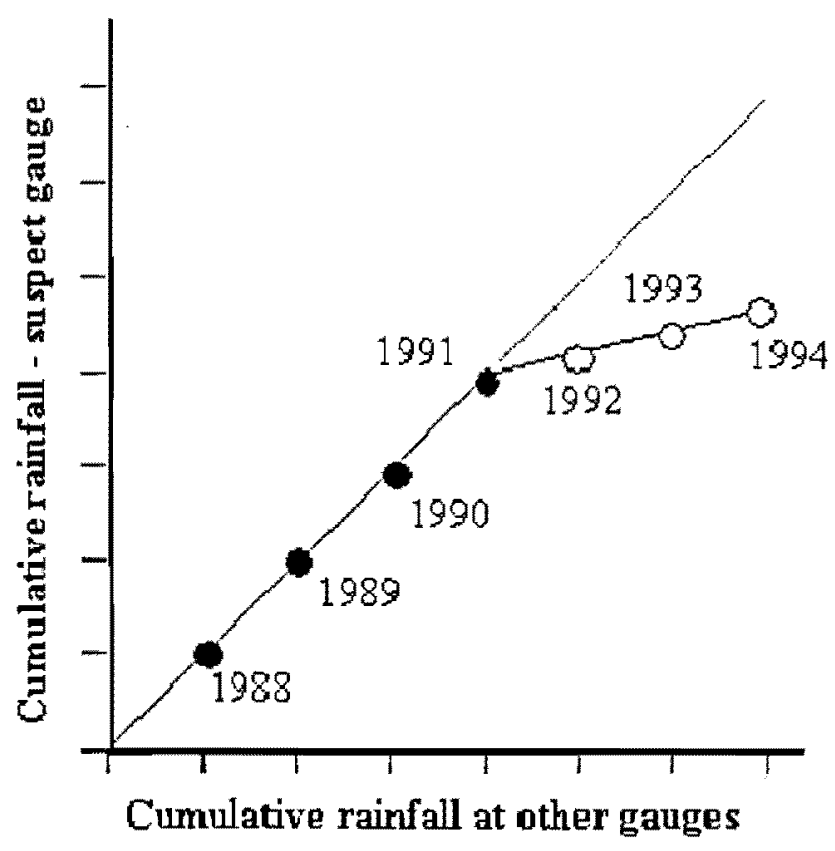

Fig 6: Double Mass Curve 


\subsection{Trend Analysis by Mann-Kendall Test}

The Mann-Kendall test is one of the statistical methods to identify trends in a time series data that do not belong to any distribution (nonparametric). This test is based on testing the null hypothesis of no trend, $H_{o}$, which means that the observed data sets are randomly ordered in time against the alternative hypothesis, $H l$, which means that the observed data sets have an increasing or decreasing trend. [24] In this test, the relative magnitudes of the data are considered instead of the absolute value of the data. Each data value is compared to all the preceding data to obtain Mann-Kendall statistic, S. A normalized test statistic $\mathrm{Z}$ is calculated based on the Mann-Kendall statistics ( $\mathrm{S}$ ) and number of data sets (n) and probability associated with this normalized test statistic is computed. Hypothesis $\mathrm{Ho}$, meaning the data sets have no trend, is rejected in favour of hypothesis $H$, meaning that there is a certain increasing or decreasing trend in the observed data sets when the probability associated with the normalized test statistics $Z$ is greater than the selected probability level of significance.[25]

The Mann-Kendall Statistics ( $\mathrm{S}$ ) for a time series $\mathrm{x}_{1}, \mathrm{x}_{2}, \mathrm{x}_{3} \ldots \ldots \ldots \ldots . . . . . \mathrm{x}_{\mathrm{j}}$ where $\mathrm{x}_{\mathrm{j}}$ represents the data at time $\mathrm{j}$, is given by:

$$
\mathrm{S}=\sum_{k=1}^{n=1} \sum_{j=k+1}^{n} \operatorname{sign}\left(x_{j}-x_{k}\right)
$$

where,

$$
\begin{aligned}
\operatorname{sign}\left(x_{j}-x_{k}\right) & =1 \text { if } x_{j}-x_{k}>0 \\
& =0 \text { if } x_{j}-x_{k}=0 \text { and } \\
& =-1 \text { if } x_{j}-x_{k}<0
\end{aligned}
$$

The first value of Mann-Kendall statistic, $\mathrm{S}$, is assigned a value of 0 . If the subsequent data value is greater than the earlier values then $S$ value is incremented by 1 . If the data value is lower than the earlier values, then the $S$ value lowered by 1 and if it is equal to 
any of the earlier values then the $S$ value remains same. The summation of all the values gives the final S. [25]

The normalized test statics $\mathrm{Z}$ is obtained by [25]:

$\mathrm{Z}=\frac{S-1}{[\operatorname{VAR}(S)]^{1 / 2}}$ if $\mathrm{S}>0$

$Z=0$ if $S=0$

$\mathrm{Z}=\frac{S+1}{[\operatorname{VAR}(S)]^{1 / 2}}$ if $\mathrm{S}<0$

Where VAR(S) is calculated as [25]:

$\operatorname{VAR}(\mathrm{S})=\frac{1}{18}\left[n(n-1)(2 n+5)-\sum_{p=1}^{g} t_{P}\left(t_{p}-1\right)\left(2 t_{p}+5\right)\right]$

where,

$\mathrm{n}=$ number of data

$\mathrm{g}=$ number of tied group (set of data having the same value)

$\mathrm{t}_{\mathrm{p}}=$ number of data in the $\mathrm{p}^{\text {th }}$ group

The probability associated with $\mathrm{Z}$ is computed as [25]:

$\mathrm{f}(\mathrm{Z})=\frac{1}{\sqrt{2 \pi}} e^{\frac{z^{2}}{2}}$

The level of significance is selected and compared with this probability. If this probability is greater than the level of significance and if the $Z$ value is positive, then it is an increasing trend where as if the $\mathrm{Z}$ value is negative, it is a decreasing trend.[25] 


\subsection{Previous Similar Studies}

Studies and reports of similar nature were studied to better understand the methods utilized in analyzing the data. Several research papers were studied and synopsis of 2 researches which are closely related to the current study being undertaken is presented here.

Daily precipitation data for a period of 30 years from 1964 to 1993 from 3366 raingage stations for the Spanish Mediterranean regions were analyzed by R. Romero et.al and the results were presented in their paper titled "A 30-year (1964-1993) Daily Rainfall Data Base for the Spanish Mediterranean Regions: First Exploratory Study" published in 1997. After preliminary data analysis only stations with at least $90 \%$ available data for the period of 30 years were selected which reduced the number of stations to 410 . The period of 30 years were divided into three decades i.e. 1964-1973, 1974-1983 and 1984-1993. After the preliminary selection of the raingages the first step taken was to fill in the missing data. Weighted average method was utilized to interpolate the missing data as:

$$
P_{i n}=\sum_{i=1}^{j} \alpha_{i j}\left(P_{j n}\right) / \sum_{i=1}^{i} \alpha_{i j}
$$

Where $\mathrm{P}_{\text {in }}=$ missing data at station $\mathrm{i}$ on day $\mathrm{n}$

$\alpha_{i j}=$ weighting factor

$\mathrm{P}_{\mathrm{j} \mathrm{n}}=$ data at other stations on day $\mathrm{n}$

The $\mathrm{j}$ reference stations were chosen within a radius of $5^{0}$ around the target station with missing data such that the chosen stations have at least a 1000 daily values with station $i$ and have no missing data at the particular day of $n$. The weighting factor was calculated based on both correlation coefficient and distance between station $i$ and $j$. 
$\alpha_{i j}=\mathrm{r}_{\mathrm{ij}}{ }^{2} / \mathrm{d}_{\mathrm{ij}}{ }^{2}$

Where $r_{i j}$ is the correlation coefficient and $d_{i j}$ is the distance between stations $i$ and $j$.

The data were then divided into seasonal and yearly records and mean of seasonal and yearly precipitation were calculated for each selected stations to identify the accumulated amount of rainfall per station and presented as such.

In the second study, Kwarteng et. al analyzed the characteristics of rainfall in the Sultanate of Oman using 27 years data recorded for 31 raingage stations from 1977 to 2003. This was presented in their paper as "Analysis of a 27-year rainfall data (19972003) in the Sultanate of Oman, published in 2009. To obtain the characteristics the average yearly and monthly rainfall was calculated for all the stations and Mann-Kendall statistical test was performed to establish a trend. Other parameters calculated were average number of rainy days, maximum daily rainfall and rainfall intensity. Rainfall intensity was investigated in two ways, first by dividing the total yearly rainfall is divided by the number of rainy days and second by dividing the rainfall events into four groups: light rainfall for less than $10 \mathrm{~mm}$, moderate for rainfall between 10 to less than $25 \mathrm{~mm}$, heavy for rainfall 25 to less than $50 \mathrm{~mm}$ and extreme for rainfall greater than $50 \mathrm{~mm}$. 


\section{Data Sources and Summary of Received Data}

The rainfall data was provided by Ontario Climate Centre, Environment Canada. Archived data for 13 different raingage stations were provided in the standard record format. Standard record format has been adopted by Environment Canada to archive the climatological data that were recorded at minutely, fifteen minute, hourly, daily or monthly interval. "Documentation for the Digital Archive of Canadian Climatological Data (Surface) Identified by Element" provided in Environment Canada website was referred for the interpretation of the provided data. According to the document, five (5) different record formats are being used by Environment Canada to archive the rainfall data which are recorded for different time intervals. The record formats are:

i. Daily record of Hourly Data;

ii. Monthly record of Daily Data;

iii. Annual record of Monthly Data;

iv. Daily record of 15 minute Data; and,

v. Hourly record of minutely Data.

It is explained in the document that each record consisted of station identification, date and element number followed by the data repeated for each time interval. The datum for each time interval is recorded as 5 digit integer plus a leading sign field and a following flag field. An explanation of the element and flag is also provided in the document. The relevant flags for the obtained data were:

$\mathrm{E}=$ Estimated

$A=$ Accumulated

$\mathrm{C}=$ Precipitation occurred, amount uncertain

$\mathrm{L}=$ Precipitation may or may not have occurred

$\mathrm{F}=$ Accumulated and estimated

$T=$ Trace 
The units and decimal position of the data is to be determined by the assigned element number.

The data received were translated based on the decoding process described in the document "Documentation for the Digital Archive of Canadian Climatological Data (Surface) Identified By Element". Different time interval data for a total of 13 raingage stations were received and decoded. From the decoding it is observed that the time interval and period of received data are not consistent among all the raingage stations. Primarily the data obtained were in the following categories:

i. Verified Daily record of Hourly Data;

ii. Unverified Daily record of Hourly Data;

iii. Verified Monthly record of Daily Data; and,

iv. Unverified Monthly record of Daily Data

\section{Verified Daily record of Hourly Data}

Verified record of Hourly Data is categorized as element 123 in the standard record format: It consists of hourly record starting 01 to 24 hours of a day. The missing hourly data are recorded as $-99999 \mathrm{M}$. The hourly data is in the unit of $0.1 \mathrm{~mm}$. Verified daily record of hourly data was available for 4 raingage stations. The stations and the period of data is shown in Table 3.

Table 3 - verified daily record of hourly data

\begin{tabular}{|l|c|c|c|}
\hline Stations & Station Code & Starting Date & End Date \\
\hline Lagoon City & 6114295 & $1998 / 05 / 05$ & $2003 / 11 / 01$ \\
\hline $\begin{array}{c}\text { Barrie WPCC } \\
=\end{array}$ & 6110557 & $1968 / 05 / 01$ & $2003 / 11 / 01$ \\
\hline $\begin{array}{l}\text { Egbert } \\
\text { Toronto Buttonville }\end{array}$ & $611 \mathrm{e} 001$ & $1997 / 04 / 01$ & $2003 / 11 / 01$ \\
\hline
\end{tabular}


The verified hourly data for the available 4 stations overlap for a period of approximately 5 years from $1998 / 05 / 05$ to $2003 / 11 / 01$.

\section{Unverified Daily record of Hourly Data:}

Unverified record of Hourly Data is categorized as element 262 in the standard record format. It consists of hourly record starting 00 to 23 hours of a day. The missing hourly data are recorded as $-99999 \mathrm{M}$. Unverified daily record of hourly data was available for 2 raingage stations. The stations and the period of data are shown in Table 4.

Table 4 - unverified daily record of hourly data

\begin{tabular}{|l|l|l|l|}
\hline Stations & Station Code & Starting Date & End Date \\
\hline Barrie Oro & 6117700 & $2004 / 03 / 27$ & $2010 / 01 / 21$ \\
\hline Lagoon City & 6114295 & $2004 / 04 / 19$ & $2010 / 01 / 21$ \\
\hline
\end{tabular}

The unverified record of hourly data available for the 2 stations overlaps for a period of approximately 6 years.

\section{Verified Monthly record of Daily Data:}

The verified monthly record of Daily Data is categorized as element 010 in the standard record format and the file system is identified by a system number 04 . The monthly data is recorded from 1 to 31 days. The records for the remaining days of the months that have less than 31 days are recorded as $-99999 \mathrm{M}$. Similarly the missing data are also recorded as $-99999 \mathrm{M}$. The hourly data is in the unit of $0.1 \mathrm{~mm}$. The verified monthly data is available for 11 different raingage stations. The stations and the period of data available are shown in Table 5.

Table 5 - verified monthly record of daily data

\begin{tabular}{|l|l|l|l|}
\hline Stations & Station Code & Starting Date & End Date \\
\hline Lagoon City & 6114295 & $1997 / 06 / 01$ & $1999 / 10 / 31$ \\
\hline Orillia & 6115818 & $1957 / 02 / 01$ & $1965 / 01 / 31$ \\
\hline Barrie WPCC & 6110557 & $1977 / 09 / 01$ & $2006 / 12 / 31$ \\
\hline Shanty Bay & 6117684 & $1973 / 01 / 01$ & $2006 / 12 / 01$ \\
\hline
\end{tabular}




\begin{tabular}{|l|l|l|l|}
\hline $\begin{array}{l}\text { Coldwater } \\
\text { Warminster }\end{array}$ & 6111769 & $1971 / 08 / 01$ & $2006 / 12 / 31$ \\
\hline Blackstock & 6150398 & $2003 / 06 / 01$ & $2006 / 10 / 31$ \\
\hline Marsh Hill & 6150790 & $2003 / 07 / 01$ & $2006 / 10 / 31$ \\
\hline Sonya & 6155000 & $2001 / 06 / 01$ & $2006 / 12 / 31$ \\
\hline Udora & 6119055 & $1989 / 09 / 01$ & $2006 / 12 / 31$ \\
\hline Baldwin & 6110480 & $2004 / 12 / 01$ & $2006 / 12 / 31$ \\
\hline Toronto Buttonville & $615 \mathrm{hmak}$ & $1986 / 05 / 01$ & $2009 / 10 / 01$ \\
\hline
\end{tabular}

The available data period varies considerably with the stations. The overlapping period for a maximum of 5 stations is approximately about 17 years from 1989/09/01 to $2006 / 12 / 31$.

\section{Unverified Monthly record of Daily Data}

The unverified monthly record of Daily Data is also categorized as element 010 in the standard record format but the file system is identified by a system number 02 . Similar to the verified monthly record of daily data, the monthly data is recorded from 1 to 31 days and the record for the remaining days of the months that have less than 31 days are recorded as $-99999 \mathrm{M}$. Similarly the missing data are also recorded as $-99999 \mathrm{M}$. The unverified monthly data is received for 3 different raingage stations. The stations and the period of data received is shown in the following table:

Table 6 - unverified monthly record of daily data

\begin{tabular}{|l|l|l|l|}
\hline Stations & Station Code & Starting Date & End Date \\
\hline Barrie Oro & 6117700 & $2004 / 03 / 01$ & $2009 / 03 / 31$ \\
\hline Egbert & $611 \mathrm{e} 001$ & $2004 / 11 / 01$ & $2010 / 01 / 31$ \\
\hline Toronto Buttonville & $615 \mathrm{hmak}$ & $2003 / 11 / 01$ & $2010 / 01 / 31$ \\
\hline
\end{tabular}


The verified hourly data for the available for the 3 stations overlap for a period of approximately 4.5 years from $2004 / 03 / 05$ to $2009 / 03 / 31$.

The location of all the stations with the received data was also obtained from Ontario Climate Centre, Environment Canada. The latitude, longitude and elevation of each of the station were noted from the Environment Canada website. The location of the stations is shown in figure 7. A graphical representation of the data received to date is presented in figure 8. A summary table of all the data available is presented in Table 7. 


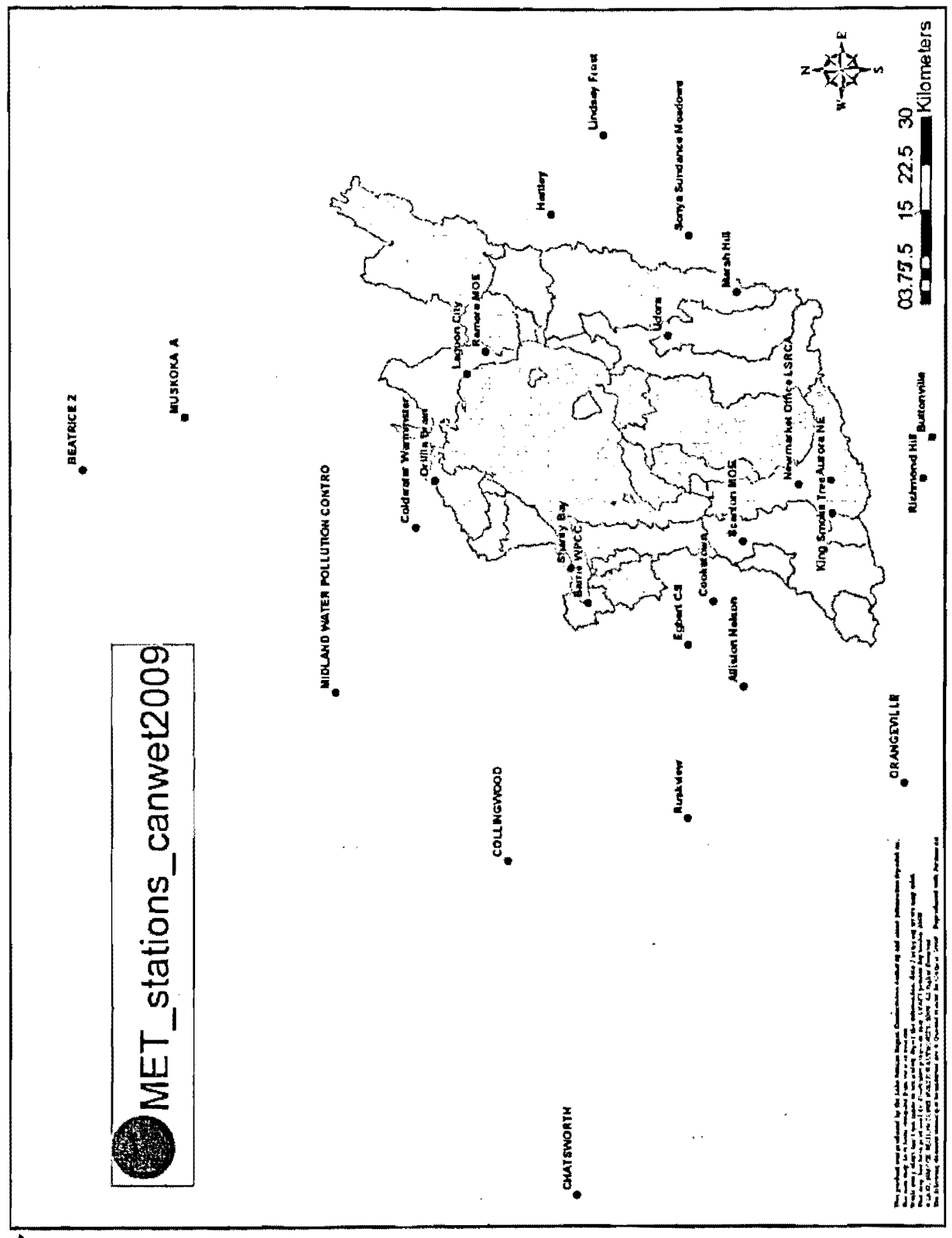

Fig 7: Location of raingage stations (provided by Ontario Climate, Environment Canada) 


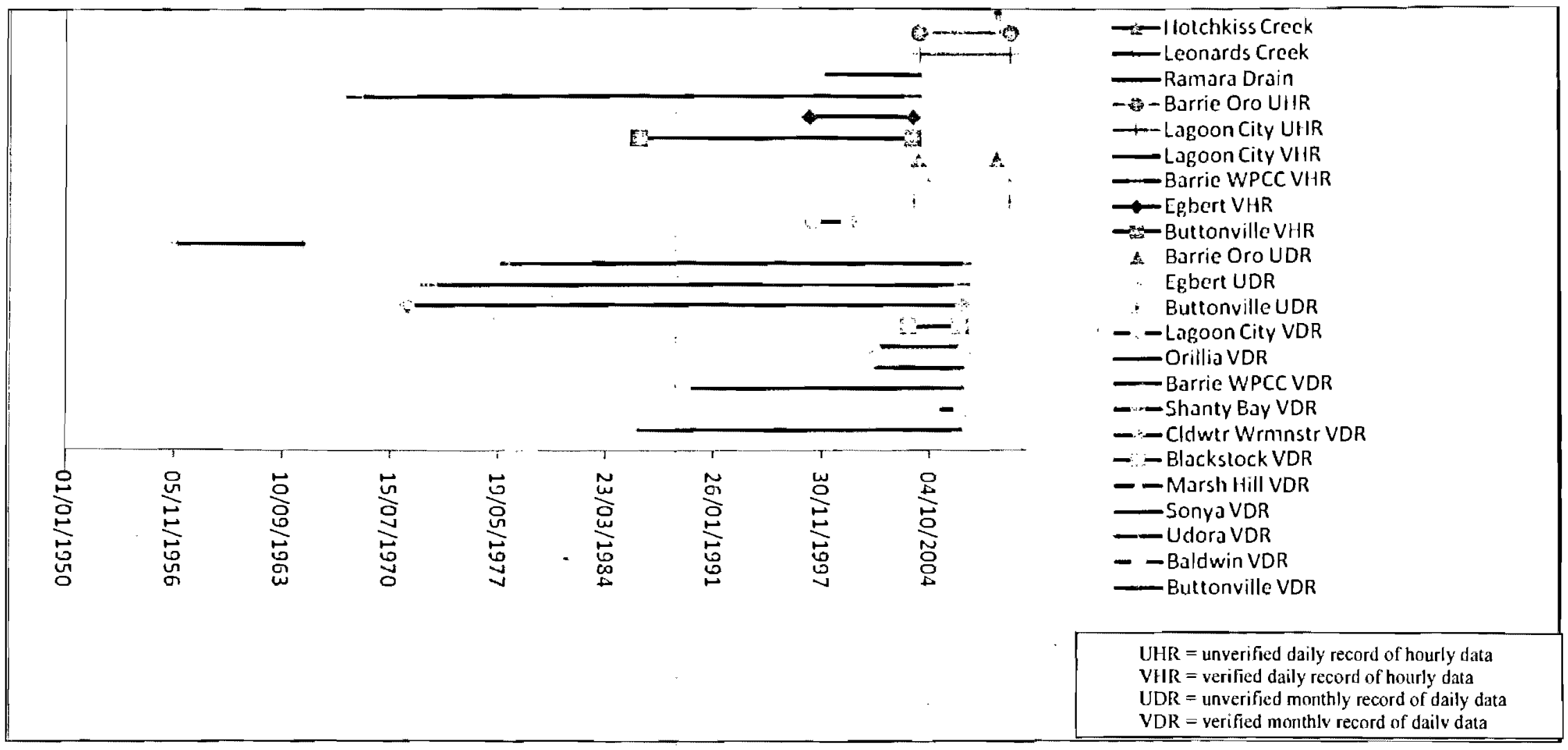

Fig 8 - Graphical representation of received rainfall data 
Table 7-Summary of received data

\begin{tabular}{|c|c|c|c|c|c|c|c|c|}
\hline \multirow{2}{*}{ Station Name } & \multirow{2}{*}{$\begin{array}{l}\text { Station } \\
\text { Code }\end{array}$} & \multirow{2}{*}{$\begin{array}{l}\text { Latitude } \\
\end{array}$} & \multirow{2}{*}{ Longitude } & \multirow{2}{*}{$\frac{\text { Elevat }}{\mathrm{m}}$} & \multicolumn{4}{|c|}{ Received Rainfall Data } \\
\hline & & & & & $\begin{array}{l}\text { Element } \\
262 \text { _ } \\
\text { unverified } \\
\text { hourly } \\
\text { rainfall } \\
\end{array}$ & $\begin{array}{l}\text { Element } \\
123 \text { _verified } \\
\text { hourly rainfall }\end{array}$ & $\begin{array}{l}\text { Element } 02 \text { - } \\
\text { unverified } \\
\text { daily rainfall }\end{array}$ & $\begin{array}{l}\text { Element } \\
\text { 04_verified } \\
\text { daily rainfall }\end{array}$ \\
\hline Barrie Oro & 6117700 & $44^{\circ} 28.800^{\prime} \mathrm{N}$ & $79^{\circ} 33.000^{\prime} \mathrm{W}$ & 289 & $\begin{array}{l}2004 / 03 / 27 \\
\text { to } \\
2010 / 01 / 21 \\
\end{array}$ & & $\begin{array}{l}2004 / 03 / 01 \text { to } \\
2009 / 03 / 31\end{array}$ & \\
\hline $\begin{array}{l}\text { Lagoon City } \\
\text { (Beaverton) }\end{array}$ & 6114295 & $44^{\circ} \mathrm{d} 33.000^{\prime} \mathrm{N}$ & $79^{\circ} 13.200^{\prime} \mathrm{W}$ & 220.7 & $\begin{array}{l}2004 / 04 / 19 \\
\text { to } \\
2010 / 01 / 21\end{array}$ & $\begin{array}{l}1998 / 05 / 05 \text { to } \\
2003 / 11 / 01\end{array}$ & & $\begin{array}{l}1997 / 06 / 01 \text { to } \\
1999 / 10 / 31\end{array}$ \\
\hline \multirow[t]{2}{*}{ Orillia } & 6115818 & $44^{\circ} 34.800^{\prime} N$ & $79^{\circ} 24.000^{\prime} \mathrm{W}$ & 224 & & & & $\begin{array}{l}1957 / 02 / 01 \text { to } \\
1965 / 01 / 31\end{array}$ \\
\hline & 6116811 & & & & & & & \\
\hline Barrie WPCC & 6110557 & $44^{\circ} 22.800^{\prime} \mathrm{N}$ & $79^{\circ} 41.400^{\prime} \mathrm{W}$ & 221 & & $\begin{array}{l}1968 / 05 / 01 \text { to } \\
2003 / 11 / 01\end{array}$ & & $\begin{array}{l}1977 / 09 / 01 \text { to } \\
2006 / 12 / 31\end{array}$ \\
\hline Shanty Bay & 6117684 & $44^{\circ} 24.000^{\prime} \mathrm{N}$ & $79^{\circ} 37.800^{\prime} \mathrm{W}$ & 250 & & & & $\begin{array}{l}1973 / 01 / 01 \text { to } \\
2006 / 12 / 31\end{array}$ \\
\hline $\begin{array}{l}\text { Coldwater } \\
\text { Warminster }\end{array}$ & 6111769 & $44^{\circ} 37.800^{\prime} \mathrm{N}$ & $79^{\circ} 32.400^{\prime} \mathrm{W}$ & 285 & & & & $\begin{array}{l}1971 / 08 / 01 \text { to } \\
2006 / 12 / 31\end{array}$ \\
\hline Egbert & $611 E 001$ & $44^{\circ} 13.800^{\prime} N$ & $79^{\circ} 46.800^{\prime} \mathrm{W}$ & 251 & & $\begin{array}{l}1997 / 04 / 01 \text { to } \\
2003 / 11 / 01\end{array}$ & $\begin{array}{l}2004 / 11 / 01 \text { to } \\
2010 / 01 / 31\end{array}$ & \\
\hline Blackstock & 6150790 & $44^{\circ} 6.000^{\prime} N$ & $78^{\circ} 49.800^{\prime} \mathrm{W}$ & 291 & & & & $\begin{array}{l}2003 / 07 / 01 \text { to } \\
2006 / 10 / 31\end{array}$ \\
\hline Marsh Hill & 6115500 & $44^{\circ} 9.000^{\prime} N$ & $79^{\circ} 4.200^{\prime} W$ & 285 & & & & $\begin{array}{l}2001 / 06 / 01 \text { to } \\
2006 / 12 / 31\end{array}$ \\
\hline
\end{tabular}




\begin{tabular}{|c|c|c|c|c|c|c|c|c|}
\hline \multirow{2}{*}{ Station Name } & \multirow{2}{*}{$\begin{array}{l}\text { Station } \\
\text { Code }\end{array}$} & \multirow{2}{*}{$\begin{array}{l}\text { Latitude } \\
\end{array}$} & \multirow[t]{2}{*}{ Longitude } & \multirow{2}{*}{$\begin{array}{c}\text { Elevat } \\
\text { jon } \\
\mathrm{m}\end{array}$} & \multicolumn{4}{|c|}{ Received Rainfall Data } \\
\hline & & & & & $\begin{array}{l}\text { Element } \\
262- \\
\text { unverified } \\
\text { hourly } \\
\text { rainfall }\end{array}$ & $\begin{array}{l}\text { Element } \\
123 \text { verified } \\
\text { hourly rainfall }\end{array}$ & $\begin{array}{l}\text { Element } 02 \text { - } \\
\text { unverified } \\
\text { daily rainfall }\end{array}$ & $\begin{array}{l}\text { Element } \\
04 \text { _verified. } \\
\text { daily rainfall }\end{array}$ \\
\hline Sonya & 6168100 & $44^{\circ} 13.200^{\circ} \mathrm{N}$ & $78^{\circ} 57.000^{\prime} W$ & 275 & & & & $\begin{array}{l}2001 / 06 / 01 \text { to } \\
2006 / 12 / 31\end{array}$ \\
\hline Udora & 6119055 & $44^{\circ} 15.600^{\prime} N$ & $79^{\circ} 9.600^{\prime} \mathrm{W}$ & 262 & & & & $\begin{array}{l}1989 / 09 / 01 \text { to } \\
2006 / 12 / 31\end{array}$ \\
\hline Baldwin & 6110480 & $44^{\circ} 16.200^{\prime} \mathrm{N}$ & $79^{\circ} 19.200^{\prime} \mathrm{W}$ & 229 & & & & $\begin{array}{l}2004 / 12 / 01 \text { to } \\
2006 / 12 / 31\end{array}$ \\
\hline Toronto Buttonville & $615 \mathrm{hmak}$ & $43^{\circ} 51.600^{\prime} \mathrm{N}$ & $79^{\circ} 22.200^{\circ} \mathrm{W}$ & 198.1 & & $\begin{array}{l}1986 / 05 / 23 \text { to } \\
2003 / 11 / 01\end{array}$ & $\begin{array}{l}2003 / 11 / 01 \text { to } \\
2010 / 01 / 31\end{array}$ & $\begin{array}{l}1986 / 05 / 01 \text { to } \\
200 / 10 / 31\end{array}$ \\
\hline
\end{tabular}




\section{Data Analysis and Results}

The intent of the data analysis is to determine the event, monthly, seasonal and annual statistics of all the stations and their spatial distribution and to determine the driest, wettest years and average annual rainfall. The process of data analysis was carried out in two phases: a. Analysis of hourly data, and b. Analysis of daily data.

\subsection{Analysis of hourly data}

The process of data analysis was started with the verified daily records of hourly data. A program in Excel VBA was developed to separate the data into different inter event time definition (IETD). The data were separated into IETDs of 6 hours, 12 hours and 24 hours and the whole rainfall data was divided into different rainfall events. For simplicity and preliminary data analysis, the missing data were converted to a zero value i.e. no rainfall. For each rainfall events, duration of rainfall, volume of the rainfall and peak value of the rainfall was calculated. The antecedent time of each rainfall event was also evaluated from the program. An example of data analysis with 12 hour IETD for Egbert station for the year 1997 is presented in Table 8. The Excel VBA program is presented in Appendix A.

From the identified independent rainfall events, various rainfall event statistics were then calculated for the whole period on record as well as for each separate year. The approach was to identify a typical year representing all the data. A typical year is the year for which the characteristics match the closest to the long term record. The statistics characteristics calculated were:
a. No. of events
b. Maximum event depth
c. Event standard deviation
d. Event skeweness
e. Geometric mean event depth
f. Log-transformed event standard deviation 
g. Log-transformed event skew

h. Total annual rainfall

i. Maximum antecedent period

j. Average antecedent period

k. Antecedent period standard deviation

An example of this calculation for 12 hour IETD for Egbert Station is presented in Table 9.

Due to insufficient number of raingage stations and only a few years of data further analysis of hourly data was not conducted. However, the program and framework for the analysis of the data has been established with this project work and the same can be adopted to analyze the data when sufficient data is available. 
Table 8- Example of data analysis with 12 hour IETD for Egbert station for the year 1997

\begin{tabular}{|c|c|c|c|c|c|c|c|c|c|c|c|c|}
\hline \multicolumn{4}{|c|}{ - Start Time } & \multicolumn{4}{|c|}{ End Time } & \multirow{2}{*}{$\frac{\text { Duration }}{\mathrm{hr}}$} & \multirow[t]{2}{*}{$\begin{array}{l}\text { Event } \\
\text { No. }\end{array}$} & \multirow{2}{*}{$\begin{array}{l}\text { Volume of } \\
\text { Rainfall } \\
\mathrm{mm}\end{array}$} & \multirow{2}{*}{$\begin{array}{l}\text { Antecedent } \\
\text { Time } \\
\frac{h r}{}\end{array}$} & \multirow{2}{*}{$\begin{array}{l}\begin{array}{l}\text { Peak } \\
\text { Rainfall }\end{array} \\
\mathrm{mm}\end{array}$} \\
\hline Year & Month & Day & Hour & Year & Month & Day & Hour & & & & & \\
\hline 1997 & 4 & 5 & 16 & 1997 & 4 & 5 & 20 & 4 & 1 & 2.5 & & 0.7 \\
\hline 1997 & 4 & 6 & 21 & 1997 & 4 & 6 & 21 & 0 & 2 & 0.4 & 25 & 0.4 \\
\hline 1997 & 4 & 12 & 8 & 1997 & 4 & 12 & 20 & 12 & 3 & 1.2 & 131 & 0.3 \\
\hline 1997 & 4 & 16 & 12 & 1997 & 4 & 16 & 18 & 6 & 4 & 1.9 & 88 & 0.5 \\
\hline 1997 & 4 & 19 & 10 & 1997 & 4 & 20 & 8 & 22 & 5 & 3.9 & 64 & 1.2 \\
\hline 1997 & 4 & 27 & 21 & 1997 & 4 & 28 & 11 & 14 & 6 & 12.1 & 181 & 2.5 \\
\hline 1997 & 5 & 24 & 21 & 1997 & 5 & 24 & 23 & 2 & 7 & 2.2 & 634 & 1.4 \\
\hline 1997 & 5 & 29 & 15 & 1997 & 5 & 30 & 6 & 15 & 8 & 6.1 & 112 & 2.3 \\
\hline
\end{tabular}


Table 9- Example of calculation of event statistics with 12 hour IETD for Egbert station

\begin{tabular}{|c|c|c|c|c|c|c|c|c|}
\hline Description & All (1997 to 2003) & 1997 & 1998 & 1999 & 2000 & 2001 & 2002 & 2003 \\
\hline No. of events & 46.857 & 9 & 35 & 48 & 58 & 62 & 47 & 44 \\
\hline Maximum event depth (volume) $\mathrm{mm}$ & 70.000 & 12.100 & 25.400 & 53.000 & 70.000 & 41.300 & 44.300 & 26.600 \\
\hline Average Event depth (volume) mm & 7.748 & 3.367 & 5.143 & 9.496 & 10.495 & 6.492 & 8.398 & 6.827 \\
\hline Event Standard Deviation & 10.492 & 3.651 & 6.823 & 11.884 & 14.902 & 8.991 & 9.818 & 6.892 \\
\hline Event Skewness & 2.347 & 2.095 & 1.694 & 1.710 & 2.123 & 2.116 & 1.756 & 1.084 \\
\hline Geometric Mean Event Depth & 3.036 & 2.198 & 2.015 & 3.404 & 4.028 & 2.404 & 3.539 & 3.440 \\
\hline $\begin{array}{l}\text { Log-transformed event standard } \\
\text { deviation }\end{array}$ & 1.525 & 0.979 & 1.479 & 1.703 & 1.529 & 1.576 & 1.526 & 1.347 \\
\hline Log-transformed event skew & -0.188 & 0.109 & 0.132 & -0.338 & -0.195 & -0.130 & -0.312 & -0.381 \\
\hline Total Annual Rainfall & 138.167 & 30.300 & 180.000 & 455.800 & 608.700 & 402.500 & 394.700 & 300.400 \\
\hline Maximum Antecedent period & 8082.000 & 634.000 & 8082.000 & 4081.000 & 3802.000 & 3862.000 & 3911.000 & 3664.000 \\
\hline Average Antecedent Period & 170.591 & 156.125 & 348.143 & 171.208 & 141.362 & 131.984 & 180.660 & 166.909 \\
\hline Antecedent Period Standard deviation & 657.826 & 200.743 & 1377.58 & 582.357 & 493.402 & 487.677 & 562.943 & 544.417 \\
\hline
\end{tabular}




\subsection{Analysis of Daily Data}

Verified Monthly records of Daily Data were analyzed to obtain the yearly, monthly and seasonal variations in rainfall in the region. The analysis was done in the following steps:
a. Data conversion and filling in missing data
b. Analysis for Yearly Statistics
c. Analysis for Seasonal Statistics
d. Analysis for Monthly Statistics

\section{Data Conversion and Filling in Missing data}

Available data from all the 11 stations were converted into excel format and studied for available and missing data. The flagged data from these stations were converted to the value represented by these data. For this the trace data represented by $00000 \mathrm{~T}$ was converted to 0 . The estimated amount of rainfall such as $00013 \mathrm{E}$ was converted to 13. Data with flag ' $\mathrm{L}$ ' such as $00000 \mathrm{~L}$ meaning "precipitation may or may not have occurred" was converted to 0 . Data with flag ' $\mathrm{C}$ ' such as $00000 \mathrm{C}$ meaning "precipitation occurred amount uncertain" was converted to zero. "Accumulated and estimated" data represented by flag ' $F$ ' such as $200 \mathrm{~F}$ was converted to 200 and similarly data represented by flag 'A' such as $200 \mathrm{~A}$ meaning "accumulated" was converted to 200 .

Table 10 summarizes the received data and missing data information after all the conversion.

Table 10: Summary of received verified monthly records of daily data

\begin{tabular}{|l|l|l|l|l|l|}
\hline Stations & $\begin{array}{l}\text { Station } \\
\text { Code }\end{array}$ & $\begin{array}{l}\text { Starting } \\
\text { Date }\end{array}$ & End Date & $\begin{array}{l}\text { Total No. } \\
\text { of Data }\end{array}$ & $\begin{array}{l}\text { Missing } \\
\text { Data }\end{array}$ \\
\hline Aurora & 6150398 & $2003 / 7 / 01$ & $2006 / 12 / 31$ & 1280 & 0 \\
\hline Lagoon City & 6114295 & $1997 / 06 / 01$ & $1999 / 10 / 31$ & 791 & 251 \\
\hline Orillia & 6115818 & $1957 / 02 / 01$ & $1965 / 01 / 31$ & 2908 & 86 \\
\hline Barrie WPCC & 6110557 & $1977 / 09 / 01$ & $2006 / 12 / 31$ & 10743 & 26 \\
\hline
\end{tabular}




\begin{tabular}{|c|c|c|c|c|c|}
\hline Stations & $\begin{array}{l}\text { Station } \\
\text { Code }\end{array}$ & $\begin{array}{l}\text { Starting } \\
\text { Date }\end{array}$ & End Date & $\begin{array}{l}\text { Total No. } \\
\text { of Data }\end{array}$ & $\begin{array}{l}\text { Missing } \\
\text { Data }\end{array}$ \\
\hline Shanty Bay & 6117684 & $1073 / 01 / 01$ & $2006 / 12 / 01$ & 12418 & 9 \\
\hline Coldwater & 6111769 & $1 9 7 \longdiv { 1 / 0 8 / 0 1 }$ & $2006 / 12 / 31$ & 12770 & 274 \\
\hline Blackstock & $615 \overline{0398}$ & $2003 / 07 / 01$ & $2006 / 10 / 31$ & 1280 & 0 \\
\hline Marsh Hill & 6150790 & $2003 / 07 / 01$ & $2006 / 10 / 31$ & 2040 & 0 \\
\hline Sonya & 6155000 & $2001 / 06 / 01$ & $2006 / 1 \overline{2 / 31}$ & 2040 & 101 \\
\hline Udora & 6119055 & $1989 / 09 / 01$ & $2006 / 12 / 31$ & 6331 & 33 \\
\hline Baldwin & 6110480 & $2004 / 12 / 01$ & $2006 / 12 / 31$ & 761 & 12 \\
\hline $\begin{array}{l}\text { Toronto } \\
\text { Buttonville }\end{array}$ & $615 \mathrm{hmak}$ & $1986 / 05 / 01$ & $2009 / 10 / 01$ & 8586 & $\overline{24}$ \\
\hline Unknown & 6115811 & $\begin{array}{l}1957 / 02 / 01 \\
\text { and } \\
1992 / 08 / 01\end{array}$ & $\begin{array}{l}1965 / 01 / 01 \\
\text { and } \\
2006 / 12 / 01\end{array}$ & $\begin{array}{l}5174 \\
\text { and } \\
5174\end{array}$ & $\begin{array}{l}39 \\
\text { and } \\
7\end{array}$ \\
\hline Unknown & 6163360 & $2001 / 06 / 01$ & $2006 / 12 / 01$ & 2040 & $\overline{226}$ \\
\hline Unknown & 6168100 & $\begin{array}{l}2001 / 06 / 01 \\
\text { and } \\
2006 / 10 / 01\end{array}$ & $\begin{array}{l}2006 / 03 / 31 \\
\text { and } \\
2006 / 12 / 01\end{array}$ & $\begin{array}{l}1765 \text { and } \\
92\end{array}$ & $\begin{array}{l}0 \text { and } \\
0\end{array}$ \\
\hline Unknown & $611 \mathrm{Kbeo}$ & $1998 / 08 / 01$ & $2006 / 12 / 01$ & 6727 & 0 \\
\hline
\end{tabular}

The initial evaluation of data revealed that only four stations namely Barrie WPCC, Coldwater Warminster, Shanty Bay and Udora had data for an approximate period of 20 years and all the other stations had insufficient data for further analysis. Based on the available data only these 4 stations were chosen for further analysis.

The received data for these 4 stations were only up to the year 2006. Available data from Environment Canada website was then used to supplement these data to the year 2010 . Data for Coldwater Warminster, Shanty Bay and Udora were available on the website and were extracted till March 2010. However, for Barrie WPCC station, data for 2007 were completely missing and only fragmented data was available for 2008 and 2009 so this was discarded and only data up to 2006 was used for further analysis. 
Missing data were then filled for these stations. Station average method was used for filling in the missing data. All the remaining 3 stations were used for the filling in the missing data from 1991 to 2006 while only 2 remaining stations were used for filling in the data for the years 2007 to 2010 and for years 1973 to 1990 . The missing data where it was missing from all the stations were left to zero value.

\section{Analysis for Yearly Statistics}

For the yearly statistics of rainfall data and to be consistent past studies for Lake Simcoe such as "Report on the Phosphorous Load on Lake Simcoe, 2004-2007", the yearly data was first separated into hydrological year starting from $1^{\text {st }}$ June to $31^{\text {st }}$ March. The rainfall amount for each hydrological year was summed up to obtain the total yearly rainfall for that year for each raingage station. Station Average method was then used to obtain the mean yearly rainfall for that hydrological year and the average of the mean yearly rainfall was calculated to obtain overall average annual rainfall for the watershed. The hydrological yearly data for all 4 stations is presented in Appendix B. Graphical representation of the yearly rainfall is presented in the following figure.

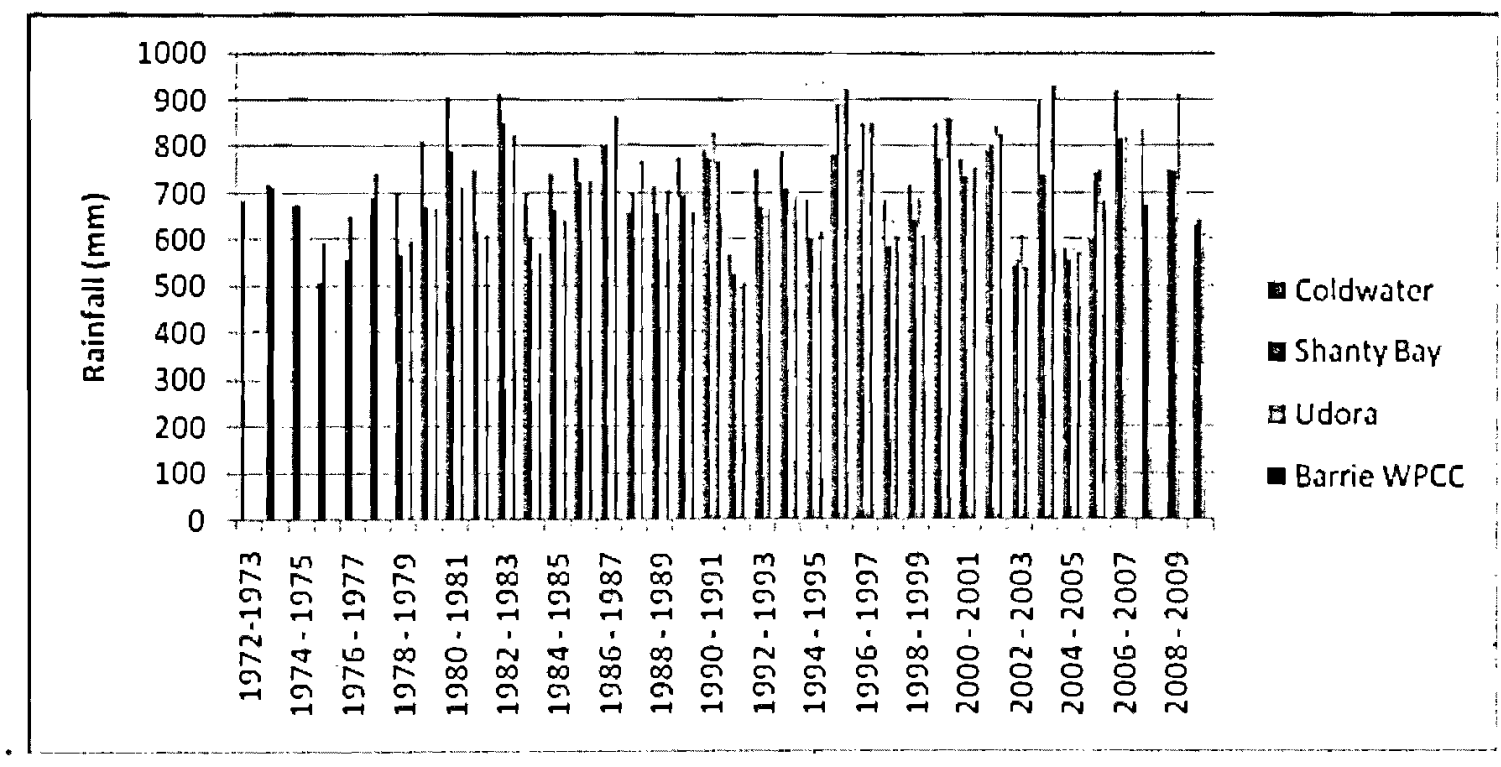

Fig 9: Hydrological Yearly Rainfall Data 
Table below presents a summary of the hydrological yearly rainfall data for the region.

Table 11: Summary of Yearly Rainfall data

\begin{tabular}{|c|c|c|c|c|c|c|c|}
\hline \multirow[t]{2}{*}{ YEAR } & \multicolumn{4}{|c|}{ Total Rainfall $(\mathrm{mm})$} & \multirow[t]{2}{*}{$\begin{array}{c}\text { Average } \\
(\mathrm{mm})\end{array}$} & \multirow[t]{2}{*}{$\begin{array}{l}\text { Geometric } \\
\text { Mean }\end{array}$} & \multirow[t]{2}{*}{$\begin{array}{l}\text { Standard } \\
\text { Deviation }\end{array}$} \\
\hline & Coldwater & $\begin{array}{c}\text { Shanty } \\
\text { Bay }\end{array}$ & Udora & $\begin{array}{l}\text { Barrie } \\
\text { WPCC }\end{array}$ & & & \\
\hline $1972-1973$ & 684.5 & & & & 684.5 & & \\
\hline $1973-1974$ & 720.1 & 712.7 & & & 716.4 & 716.4 & 5.23 \\
\hline $1974-1975$ & 672.6 & 672.9 & & & 672.8 & 672.7 & 0.21 \\
\hline $1975-1976$ & 507.6 & 592.0 & & & 549.8 & 548.2 & 59.68 \\
\hline $1976-1977$ & 557.1 & 650.2 & & & 603.7 & 601.9 & 65.83 \\
\hline $1977-1978$ & 689.8 & 741.6 & & & 715.7 & 715.2 & 36.63 \\
\hline $1978-1979$ & 700.4 & 568.0 & & 594.3 & 620.9 & 618.3 & 70.09 \\
\hline $1979-1980$ & 811.3 & 670.1 & & 665.0 & 715.5 & 712.4 & 83.03 \\
\hline $1980-1981$ & 904.5 & 790.4 & & 713.7 & 802.9 & 799.1 & 96.01 \\
\hline $1981-1982$ & 747.4 & 616.6 & & 610.2 & 658.1 & 655.2 & 77.43 \\
\hline $1982-1983$ & 912.8 & 850.8 & & 823.1 & 862.2 & 861.4 & 45.93 \\
\hline $1983-1984$ & 696.4 & 607.8 & & 571.5 & 625.2 & 623.1 & 64.25 \\
\hline $1984-1985$ & 740.4 & 663.4 & & 642.0 & 681.9 & 680.7 & 51.75 \\
\hline $1985-1986$ & 776.1 & 721.8 & & 725.7 & 741.2 & 740.8 & 30.26 \\
\hline $1986-1987$ & 798.8 & 802.0 & & 862.8 & 821.2 & 820.7 & 36.06 \\
\hline $1987-1988$ & 658.0 & 701.2 & & 766.6 & 708.6 & 707.2 & 54.68 \\
\hline $1988-1989$ & 716.8 & 655.2 & & 705.5 & 692.5 & 692.0 & 32.79 \\
\hline $1989-1990$ & 776.1 & 694.9 & & 658.8 & 709.9 & 708.3 & 60.08 \\
\hline $1990-1991$ & 794.2 & 775.4 & 829.1 & 768.2 & 791.7 & 791.4 & 27.24 \\
\hline $1991-1992$ & 568.6 & 525.0 & 502.2 & 506.8 & 525.7 & 525.0 & 30.28 \\
\hline $1992-1993$ & 751.0 & 669.6 & 653.8 & 665.2 & 684.9 & 683.9 & 44.57 \\
\hline $1993-1994$ & 788.4 & 708.6 & 670.9 & 690.1 & 714.5 & 713.1 & 51.62 \\
\hline $1994-1995$ & 685.0 & 599.2 & 565.5 & 615.5 & 616.3 & 614.8 & 50.31 \\
\hline $1995-1996$ & 781.2 & 893.0 & 891.3 & 921.7 & 871.8 & 870.1 & 61.99 \\
\hline $1996-1997$ & 752.3 & 850.0 & 840.0 & 849.0 & 822.8 & 821.8 & 47.23 \\
\hline $1997-1998$ & 682.7 & 587.0 & 654.7 & 606.5 & 632.7 & 631.6 & 43.80 \\
\hline $1998-1999$ & 715.0 & 642.2 & 691.5 & 610.5 & 664.8 & 663.5 & 47.22 \\
\hline $1999-2000$ & 849.5 & 775.4 & 862.7 & 859.8 & 836.8 & 836.1 & 41.35 \\
\hline $2000-2001$ & 770.7 & 735.4 & 731.9 & 755.7 & 748.4 & 748.3 & 18.18 \\
\hline $2001-2002$ & 794.0 & 803.2 & 843.9 & 825.6 & 816.7 & 816.5 & 22.47 \\
\hline $2002-2003$ & 544.3 & 558.0 & 608.6 & 539.0 & 562.5 & 561.8 & 31.77 \\
\hline $2003-2004$ & 896.7 & 739.0 & 815.8 & 928.8 & 845.1 & 841.8 & 85.22 \\
\hline $2004-2005$ & 583.3 & 555.6 & 581.6 & 570.0 & 572.6 & 572.5 & 12.79 \\
\hline $2005-2006$ & 601.4 & 745.4 & 749.9 & 685.3 & 695.5 & 692.8 & 69.30 \\
\hline $2006-2007$ & 920.2 & 818.9 & 822.1 & & 853.7 & 852.5 & 57.59 \\
\hline
\end{tabular}




\begin{tabular}{|c|c|c|c|c|c|c|c|}
\hline \multirow{2}{*}{ YEAR } & \multicolumn{4}{|c|}{ Total Rainfall $(\mathrm{mm})$} & $\begin{array}{c}\text { Average } \\
\text { (mm) }\end{array}$ & $\begin{array}{l}\text { Geometric } \\
\text { Mean }\end{array}$ & $\begin{array}{l}\text { Standard } \\
\text { Deviation }\end{array}$ \\
\cline { 2 - 9 } & Coldwater & $\begin{array}{c}\text { Shanty } \\
\text { Bay }\end{array}$ & Udora & $\begin{array}{c}\text { Barrie } \\
\text { WPCC }\end{array}$ & & \\
\hline $2007-2008$ & 836.6 & 673.0 & 560.0 & & 689.9 & 680.6 & 139.07 \\
\hline $2008-2009$ & 752.5 & 748.0 & 910.9 & & 803.8 & 800.4 & 92.79 \\
\hline $2009-2010$ & 630.2 & 640.9 & 614.8 & & 628.6 & 628.5 & 13.12 \\
\hline Average All & 730.7 & 696.1 & 720.1 & 704.9 & 709.5 & 708.7 & \\
\hline
\end{tabular}

The overall annual average rainfall for all 4 stations is calculated as $709.5 \mathrm{~mm}$. A plot of overall average rainfall over the yearly variation is shown in the following figure.

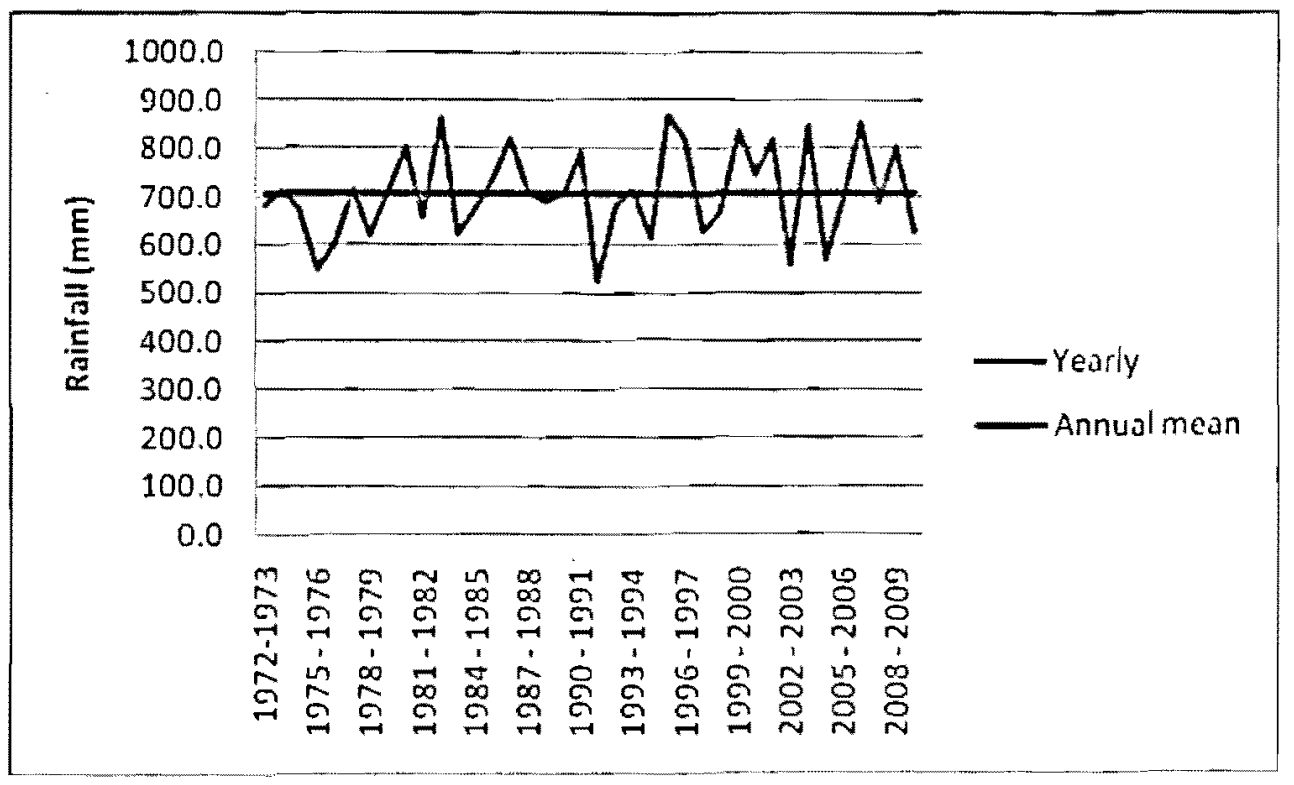

Fig 10: Yearly Rainfall Data with mean Annual Rainfall

The analyzed yearly data were then ranked in the order of highest to lowest value for all the stations to obtain the wettest and driest year. The following table presents the ranking of the yearly data. 
Table 12: Ranking of Yearly Rainfall data

\begin{tabular}{|c|c|c|c|c|c|c|c|c|c|c|}
\hline \multirow[t]{2}{*}{ Rank } & \multicolumn{2}{|c|}{ Coldwater } & \multicolumn{2}{|c|}{ Shanty Bay } & \multicolumn{2}{|c|}{ Barrie WPCC } & \multicolumn{2}{|c|}{ Udora } & \multicolumn{2}{|c|}{ Average } \\
\hline & Year & Rainfall & Year & Rainfall & Year & Rainfall & Year & Rainfall & Year & Rainfall \\
\hline 1 & $2006-2007$ & 920.2 & $1995-1996$ & 893.0 & $2003-2004$ & 928.8 & $2008-2009$ & 910.9 & $1995-1996$ & 871.8 \\
\hline 2 & $1982-1983$ & 912.8 & $1982-1983$ & 850.8 & $1995-1996$ & 921,7 & $1995-1996$ & 891.3 & $1982-1983$ & 862.2 \\
\hline 3 & $1980-1981$ & 904.5 & $1996-1997$ & 850.0 & $1986-1987$ & 862.8 & $1999-2000$ & 862.7 & $2006-2007$ & 853.7 \\
\hline 4 & $2003-2004$ & 896.7 & $2006-2007$ & 818.9 & $1999-2000$ & 859.8 & $2001-2002$ & 843.9 & $2003-2004$ & 845.1 \\
\hline 5 & $1999-2000$ & 849.5 & $2001-2002$ & 803.2 & $1996-1997$ & 849.0 & $1996-1997$ & 840.0 & $1999-2000$ & 836.8 \\
\hline 6 & $2007-2008$ & 836.6 & $1986-1987$ & 802.0 & $2001-2002$ & 825.6 & $1990-1991$ & 829.1 & $1996-1997$ & 822.8 \\
\hline 7 & $1979-1980$ & 811.3 & $1980-1981$ & 790.4 & $1982-1983$ & 823.1 & $2006-2007$ & 822.1 & $1986-1987$ & 821.2 \\
\hline 8 & $1986-1987$ & 798.8 & $1999-2000$ & 775.4 & 1990 - 1991 & 768.2 & $2003-2004$ & 815.8 & $2001-2002$ & 816.7 \\
\hline 9 & $1990-1991$ & 794.2 & $1990-1991$ & 775.4 & $1987-1988$ & 766.6 & $2005-2006$ & 749.9 & $2008-2009$ & 803.8 \\
\hline 10 & $2001-2002$ & 794.0 & $2008-2009$ & 748.0 & $2000-2001$ & 755.7 & $2000-2001$ & 731.9 & $1980-1981$ & 802.9 \\
\hline 11 & $1993-1994$ & 788.4 & $2005-2006$ & 745.4 & $1985-1986$ & 725.7 & 1998 - 1999 & 691.5 & $1990-1991$ & 791.7 \\
\hline 12 & $1995-1996$ & 781.2 & $1977-1978$ & 741.6 & $1980-1981$ & 713.7 & $1993-1994$ & 670.9 & $2000-2001$ & 748.4 \\
\hline 13 & $1989-1990$ & 776.1 & $2003-2004$ & 739.0 & $1988-1989$ & 705.5 & $1997-1998$ & 654.7 & $1985-1986$ & 741.2 \\
\hline 14 & $1985-1986$ & 776.1 & $2000-2001$ & 735.4 & $1993-1994$ & 690.1 & $1992-1993$ & 653,8 & $1973-1974$ & 716.4 \\
\hline 15 & $2000-2001$ & 770.7 & $1985-1986$ & 721.8 & $2005-2006$ & 685.3 & $2009-2010$ & 614.8 & $1977-1978$ & 715.7 \\
\hline 16 & $2008-2009$ & 752.5 & $1973-1974$ & 712.7 & $1992-1993$ & 665.2 & $2002-2003$ & 608.6 & $1979-1980$ & 715.5 \\
\hline 17 & $1996-1997$ & 752.3 & $1993-1994$ & 708.6 & $1979-1980$ & 665.0 & $2004-2005$ & 581.6 & 1993 - 1994 & 714.5 \\
\hline 18 & $1992-1993$ & 751.0 & $1987-1988$ & 701.2 & $1989-1990$ & 658.8 & $1994-1995$ & 565.5 & $1989-1990$ & 709.9 \\
\hline 19 & $1981-1982$ & 747.4 & $1989-1990$ & $694.9^{\circ}$ & $1984-1985$ & 642.0 & $2007-2008$ & 560.0 & $1987-1988$ & 708.6 \\
\hline 20 & $1984-1985$ & 740.4 & $2007-2008$ & 673.0 & $1994-1995$ & 615.5 & $1991-1992$ & 502.2 & $2005-2006$ & 695.5 \\
\hline 21 & $1973-1974$ & 720.1 & $1974-1975$ & 672.9 & 1998 - 1999 & 610.5 & & & $1988-1989$ & 692.5 \\
\hline 22 & $1988-1989$ & 716.8 & $1979-1980$ & 670.1 & $1981-1982$ & 610.2 & & & $2007-2008$ & 689.9 \\
\hline 23 & 1998 - 1999 & 715.0 & $1992-1993$ & 669.6 & $1997-1998$ & 606.5 & & & $1992-1993$ & 684.9 \\
\hline 24 & $1978-1979$ & 700.4 & $1984-1985$ & 663.4 & $1978-1979$ & 594.3 & & & $1972-1973$ & 684.5 \\
\hline
\end{tabular}




\section{Table 12: Ranking of Yearly Rainfall data}

\begin{tabular}{|c|c|c|c|c|c|c|c|c|c|c|}
\hline \multirow[t]{2}{*}{ Rank } & \multicolumn{2}{|c|}{ Coldwater } & \multicolumn{2}{|c|}{ Shanty Bay } & \multicolumn{2}{|c|}{ Barrie WPCC } & \multicolumn{2}{|c|}{ Udora } & \multicolumn{2}{|c|}{ Average } \\
\hline & Year & Rainfall & Year & Rainfall & Year & Rainfall & Year & Rainfall & Year & Rainfall \\
\hline 25 & $1983-1984$ & 696.4 & $1988-1989$ & 655.2 & $1983-1984$ & 571.5 & & & $1984-1985$ & 681.9 \\
\hline 26 & $1977-1978$ & 689.8 & $1976-1977$ & 650.2 & $2004-2005$ & 570.0 & & & $1974-1975$ & 672.8 \\
\hline 27 & $1994-1995$ & 685.0 & $1998-1999$ & 642.2 & $2002-2003$ & 539.0 & & & $1998-1999$ & 664.8 \\
\hline 28 & $1972-1973$ & 684.5 & $2009-2010$ & 640.9 & $1991-1992$ & 506.8 & & & $1981-1982$ & 658.1 \\
\hline 29 & $1997-1998$ & 682.7 & $1981-1982$ & 616.6 & & & & & $1997-1998$ & 632.7 \\
\hline 30 & $1974-1975$ & 672.6 & $1983-1984$ & 607.8 & & & & & $2009-2010$ & 628.6 \\
\hline 31 & $1987-1988$ & 658.0 & $1994-1995$ & 599.2 & & & & & $1983-1984$ & 625.2 \\
\hline 32 & $2009-2010$ & 630.2 & $1975-1976$ & 592,0 & & & & & $1978-1979$ & 620.9 \\
\hline 33 & $2005-2006$ & 601.4 & $1997-1998$ & 587.0 & & & & & $1994-1995$ & 616.3 \\
\hline 34 & $2004-2005$ & 583.3 & $1978-1979$ & 568.0 & & & & & $1976-1977$ & 603.7 \\
\hline 35 & $1991-1992$ & 568.6 & $2002-2003$ & 558.0 & & & & & $2004-2005$ & 572.6 \\
\hline 36 & $1976-1977$ & 557.1 & $2004-2005$ & 555.6 & & & & & $2002-2003$ & 562.5 \\
\hline 37 & $2002-2003$ & 544.3 & $1991-1992$ & 525.0 & & & & & $1975-1976$ & 549.8 \\
\hline 38 & $1975-1976$ & 507.6 & & & & & & & $1991-1992$ & 525.7 \\
\hline
\end{tabular}


From the ranking table it is observed that highest rainfall was recorded at different raingage stations in different hydrological years. The highest yearly rainfall recorded at Coldwater Warminster was in 2006-2007; at Shanty Bay in 1995-1996; at Barrie WPCC in 2003-2004 and at Udora in 2008-2009. However, the average value obtained from the cumulative data of all the raingage stations showed that overall average highest rainfall was in the hydrological year 1995-1996. Based on the result, it is inferred that hydrological year 1995-1996 was the wettest year for the watershed. The mean yearly rainfall amount for hydrological year 1995-1996 was $871.8 \mathrm{~mm}$.

Similarly, different raingage stations recorded the lowest rainfall in different hydrological years. Based on the average data of all the stations, it is seen that hydrological year 19911992 was the driest year with only $525.7 \mathrm{~mm}$ of rainfall.

Mann-Kendall test was performed on the data to establish a trend in the rainfall records. The theoretical background of Mann-Kendall test is explained in section 2.6 of this report. MAKESENS version 1.0 (2002), an excel program developed by Finnish Metrological Institute - "Conduct Mann-Kendall test and Sen's Slope Estimate for the Trend of Annual Data" was used to conduct the test. A $95 \%$ level of significance was chosen to conduct the test. The test was then performed for all 4 stations. Table below summarizes the result obtained from the test.

Table 13: Result of Mann-Kendall test on yearly rainfall data

\begin{tabular}{|l|l|l|l|l|l|l|}
\hline Station & $\begin{array}{l}\text { Starting } \\
\text { Hydrological } \\
\text { Year }\end{array}$ & $\begin{array}{l}\text { Last } \\
\text { Hydrological } \\
\text { Year }\end{array}$ & $\begin{array}{l}\text { Number of } \\
\text { readings }\end{array}$ & $\begin{array}{l}\text { Normalized } \\
\text { Test } \\
\text { Statistics Z }\end{array}$ & $\begin{array}{l}\text { Computed } \\
\text { Probability }\end{array}$ & $\begin{array}{l}\text { Trend at } \\
\text { 95\% Level of } \\
\text { significance }\end{array}$ \\
\hline Coldwater & $1972-1973$ & $2009-2010$ & 38 & 1.08 & 0.860 & No Trend \\
\hline Shanty Bay & $1973-1974$ & $2009-2010$ & 37 & 0.65 & 0.743 & No Trend \\
\hline Udora & $1990-1991$ & $2009-2010$ & 20 & 0.36 & 0.639 & No Trend \\
\hline Barrie WpCC & $1978-2005$ & $2005-2006$ & 28 & 0.61 & 0.730 & No Trend \\
\hline
\end{tabular}


Graphical representation of the test for the 4 stations are presented in the following figures.

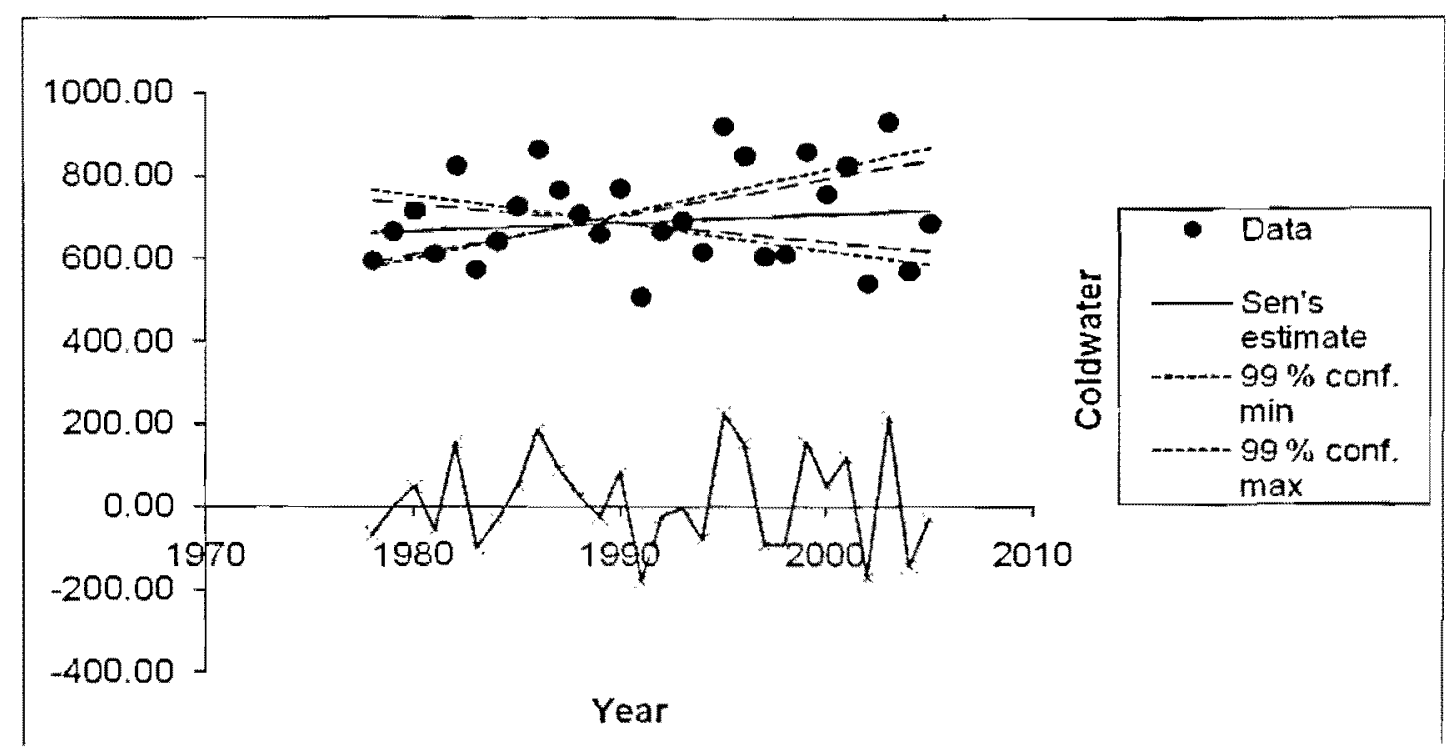

Fig11: Graphical presentation of Mann-Kendall test, Coldwater Warminster

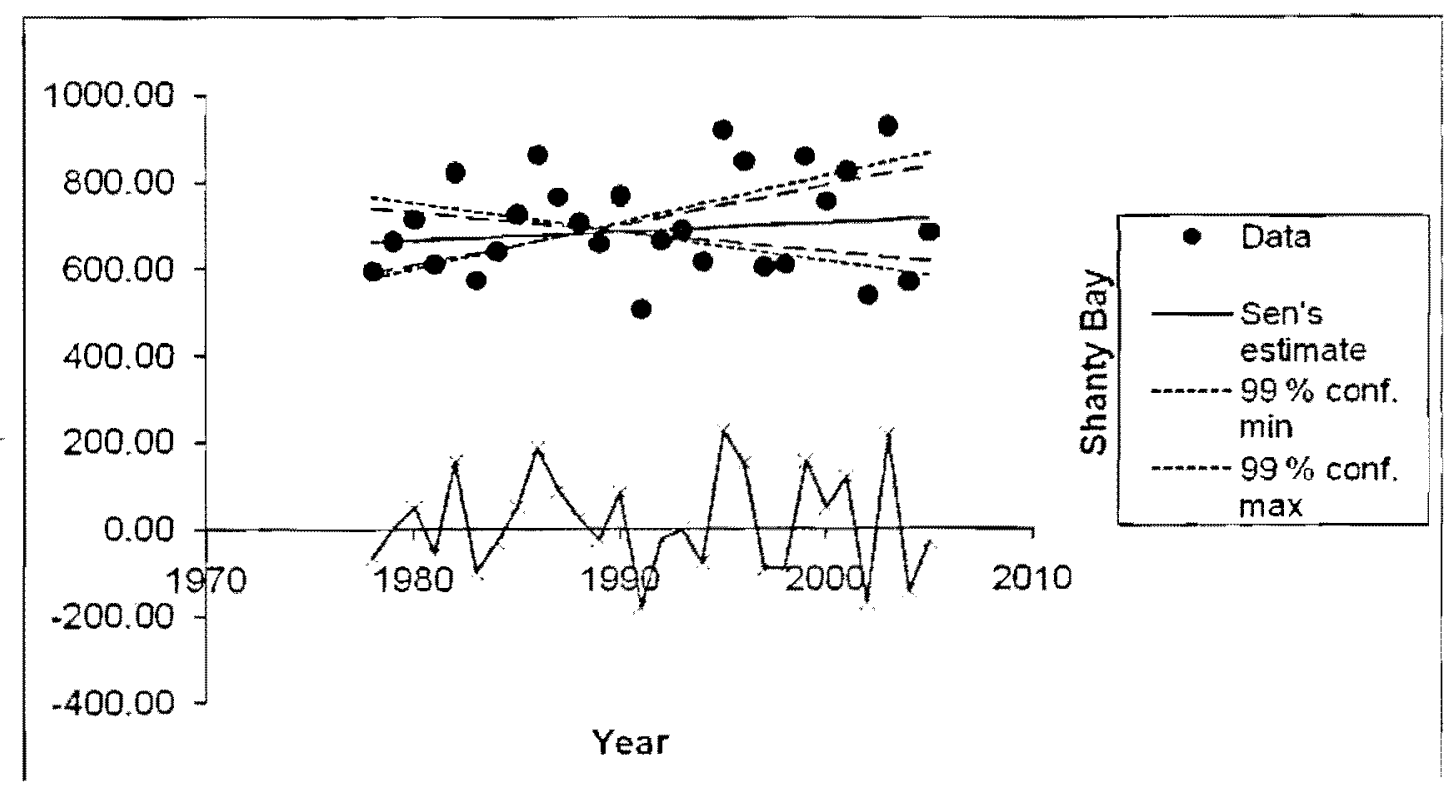

Fig12: Graphical presentation of Mann-Kendall test, Shanty Bay 


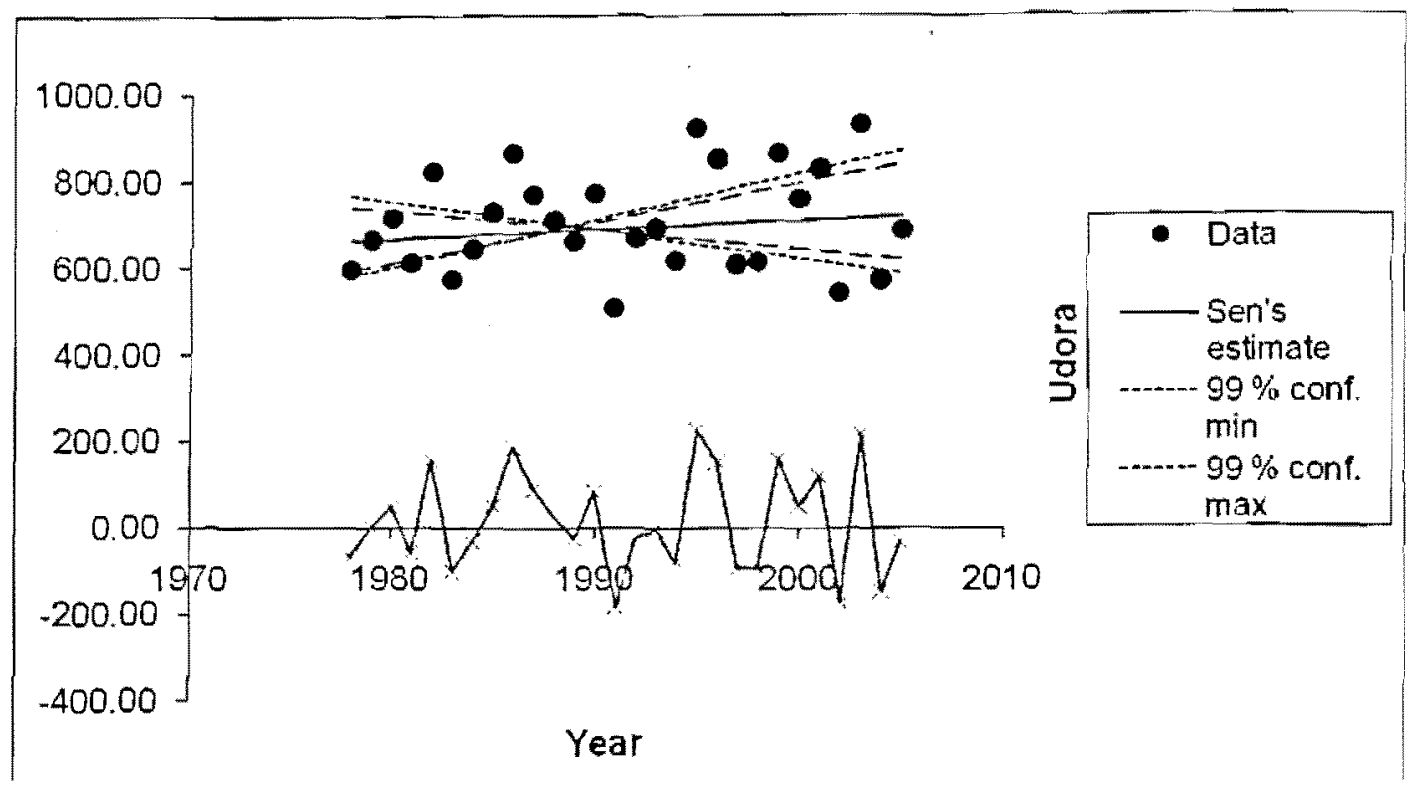

Fig13: Graphical presentation of Mann-Kendall test, Udora

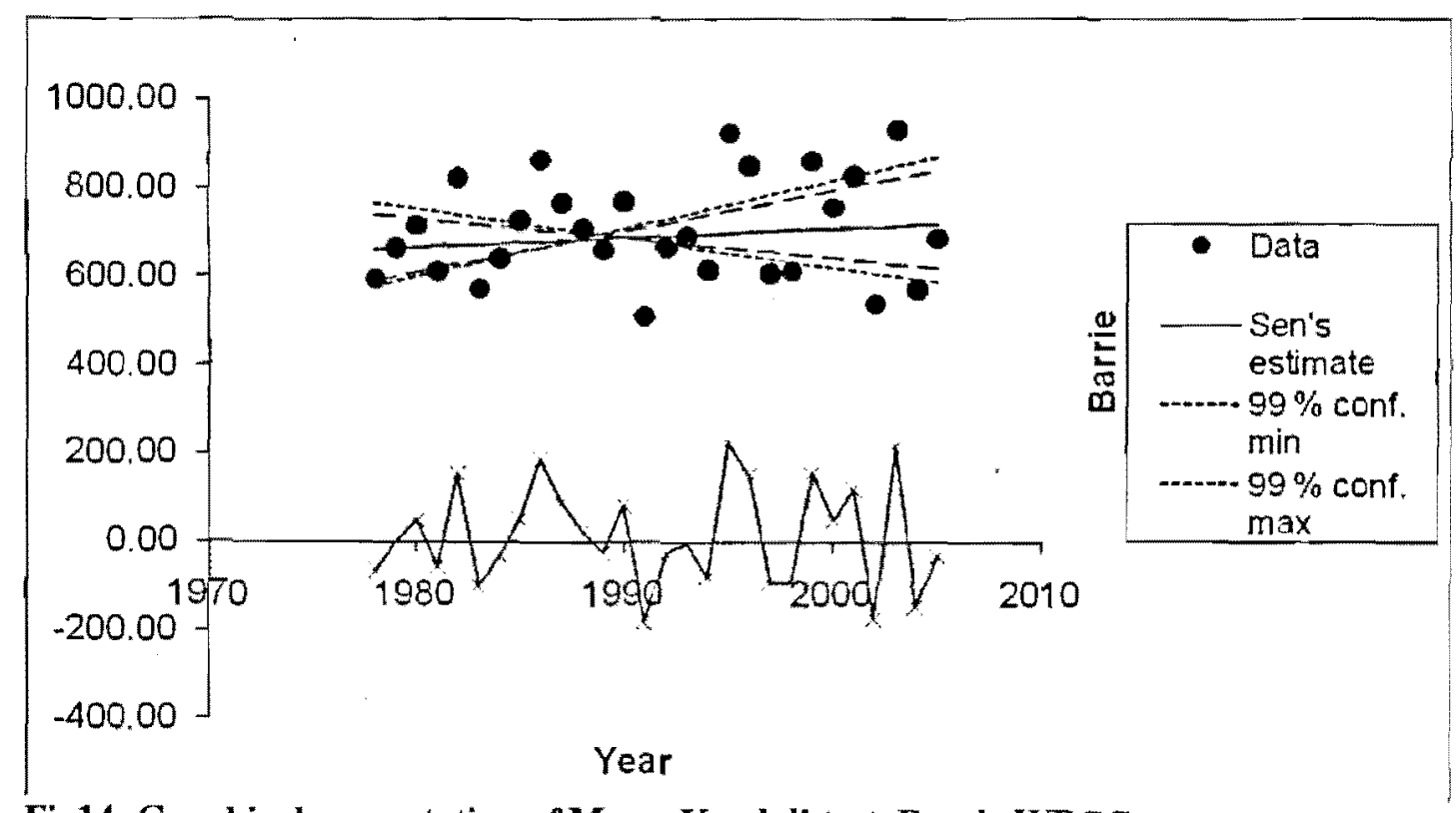

Fig14: Graphical presentation of Mann-Kendall test, Barrie WPCC

Normalized test statistics $\mathrm{Z}$ and probability associated with $\mathrm{Z}$ were calculated for the yearly data for all the 4 stations. None of the values of the probability were exceeding the selected level of significance (95\%). Based on the results of the Mann-Kendall test no trend is established on the yearly rainfall data. 


\section{Analysis for Seasonal Statistics}

Analysis of data was done to obtain the seasonal variation of the rainfall. Data were separated into four seasons based on climatologic condition of the region. Winter season comprised of December, January and February; spring comprised of March, April and May; summer comprised of June, July and August and fall comprised of September, October and November. Rainfall for each year per season was added and averaged to obtain average seasonal rainfall for each raingage station. Seasonal average for the watershed was then obtained by Station Average method. The analyzed data for the seasonal variation is presented in appendix D. Graphical representation of the seasonal rainfall is presented in the following figure.

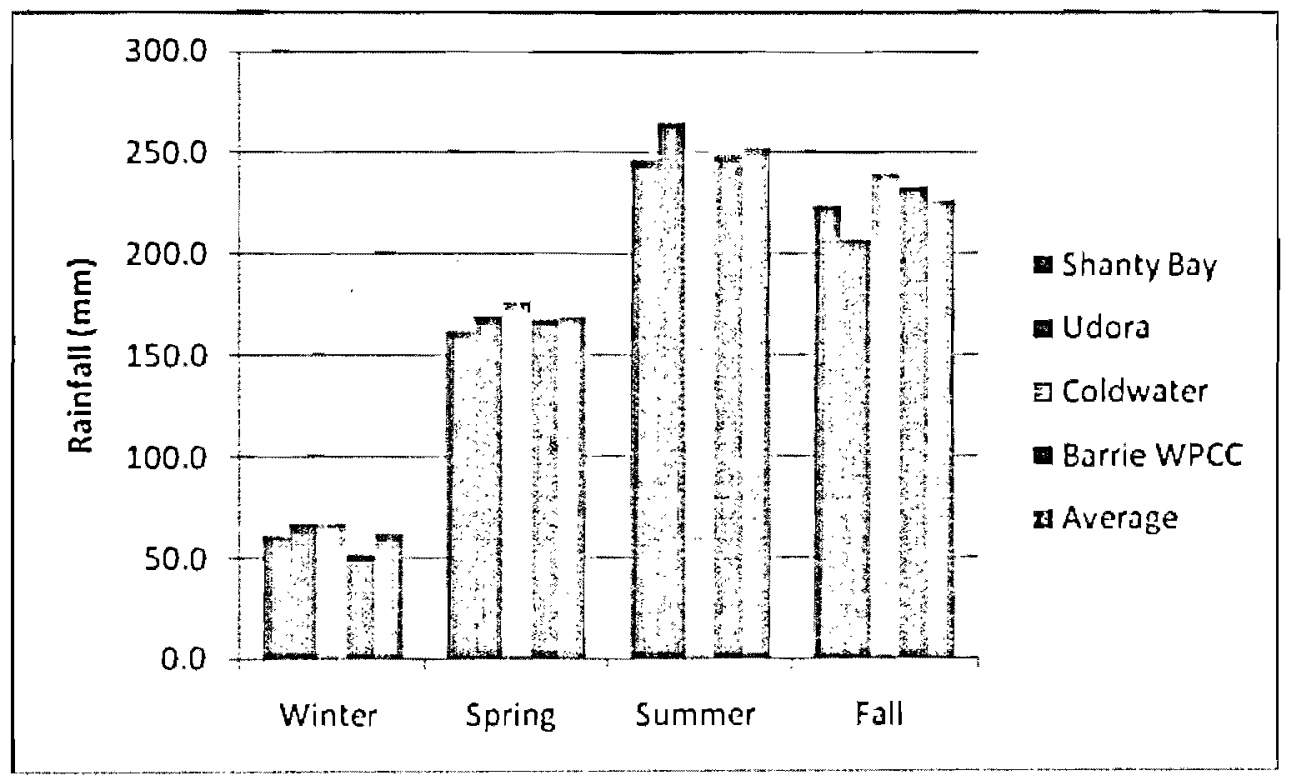

Fig 15: Seasonal Rainfall Data 
Table below presents a summary of the analyzed seasonal rainfall data for the 4 raingage stations.

Table 14: Summary of Seasonal Rainfall Data

\begin{tabular}{|c|c|c|c|c|c|c|c|}
\hline \multirow[t]{2}{*}{ Season } & \multicolumn{4}{|c|}{ Rainfall (mm) } & \multirow[t]{2}{*}{$\begin{array}{c}\text { Average } \\
\text { (mm) }\end{array}$} & \multirow[t]{2}{*}{$\begin{array}{l}\text { Geometric } \\
\text { Mean }\end{array}$} & \multirow[t]{2}{*}{$\begin{array}{l}\text { Standard } \\
\text { Deviation }\end{array}$} \\
\hline & Shanty Bay & Udora & Coldwater & $\begin{array}{l}\text { Barrie } \\
\text { WPCC }\end{array}$ & & & \\
\hline $\begin{array}{l}\text { Winter (Dec, } \\
\text { Jan, Feb) }\end{array}$ & 60.8 & 67.0 & 67.5 & 52.2 & 61.89 & 61.57 & 7.12 \\
\hline $\begin{array}{l}\text { Spring (Mar, } \\
\text { Apr, May) }\end{array}$ & 162.2 & 169.7 & 176.7 & 168.6 & 169.27 & 169.19 & 5.94 \\
\hline $\begin{array}{l}\text { Summer (Jun, } \\
\text { July, Aug) }\end{array}$ & 246.8 & 264.8 & 248.5 & 249.2 & 252.35 & 252.25 & 8.37 \\
\hline $\begin{array}{l}\text { Fall (Sep, Oct, } \\
\text { Nov) }\end{array}$ & 224.5 & 207.7 & 239.9 & 233.0 & 226.26 & 225.94 & 13,87 \\
\hline
\end{tabular}

The analyzed seasonal data were then ranked in the order of highest to lowest value for all the stations to obtain the wettest and driest season. The following table presents the ranking of the seasonal data

Table 15: Ranking of Seasonal Rainfall data

\begin{tabular}{|c|c|c|c|c|c|c|c|c|c|c|}
\hline \multirow{2}{*}{ Rank } & \multicolumn{2}{|c|}{ Shanty Bay } & \multicolumn{2}{c|}{ Udora } & \multicolumn{2}{c|}{ Coldwater } & \multicolumn{2}{c|}{ Barrie Wpcc } & \multicolumn{2}{c|}{ Average } \\
\cline { 2 - 11 } & Season & Rainfall & Season & Rainfall & Season & Rainfall & Season & Rainfall & Season & Rainfall \\
\hline 1 & Summer & 246.8 & Summer & 264.8 & Summer & 248.5 & Summer & 249.2 & Summer & 248.88 \\
\hline 2 & Fall & 224.5 & Fall & 207.7 & Fall & 239.9 & Fall & 233.0 & Fall & 236.43 \\
\hline 3 & Spring & 162.2 & Spring & 169.7 & Spring & 176.7 & Spring & 168.6 & Spring & 172.61 \\
\hline 4 & Winter & 60.8 & Winter & 67.0 & Winter & 67.5 & Winter & 52.2 & Winter & 59.84 \\
\hline
\end{tabular}

From the ranking table it is observed that highest and lowest rainfalls were recorded in the same season for all the raingage stations. It is observed that the summer season is the wettest season with an average rainfall of $248.9 \mathrm{~mm}$. However, fall season also has comparable amount of rainfall with an average of $236.4 \mathrm{~mm}$. Winter is the driest season with only an average of $59.8 \mathrm{~mm}$ rainfall. 
Mann-Kendall test was performed on the seasonal data of all years to establish a trend in seasonal variation over the years. The same program, MAKESENS version 1.0 (2002) was used for the test. Similar to the test for yearly data, a $95 \%$ level of significance was chosen to conduct the test. The test was performed for all 4 stations and for all the years of available data. Table below summarizes the result obtained from the test.

Table 16: Result of Mann-Kendall test on seasonal rainfall data

\begin{tabular}{|c|c|c|c|c|c|c|}
\hline Station & $\begin{array}{l}\text { Starting } \\
\text { Year }\end{array}$ & $\begin{array}{l}\text { Last } \\
\text { Year }\end{array}$ & $\begin{array}{l}\text { Number of } \\
\text { readings }\end{array}$ & $\begin{array}{l}\text { Normalized } \\
\text { Test } \\
\text { Statistics Z }\end{array}$ & $\begin{array}{l}\text { Computed } \\
\text { Probability }\end{array}$ & $\begin{array}{l}\text { Trend at } \\
95 \% \text { Level } \\
\text { of } \\
\text { significance }\end{array}$ \\
\hline \multicolumn{7}{|c|}{ Coldwater } \\
\hline Winter & 1972 & 2008 & 37 & 2.26 & 0.988 & Increasing \\
\hline Spring & 1972 & 2008 & 37 & 1.22 & 0.888 & No Trend \\
\hline Summer & 1972 & 2008 & 37 & -1.22 & 0.112 & No Trend \\
\hline Fall & 1972 & 2008 & 37 & -0.51 & 0.305 & No Trend \\
\hline \multicolumn{7}{|c|}{ Shanty Bay } \\
\hline Winter & 1973 & 2009 & 36 & 2.34 & 0.990 & Increasing \\
\hline Spring & 1973 & 2009 & 36 & 0.80 & 0.789 & No Trend \\
\hline Summer & 1973 & 2009 & 36 & -0.40 & 0.346 & No Trend \\
\hline Fall & 1973 & 2009 & 36 & -0.18 & 0.430 & No Trend \\
\hline \multicolumn{7}{|l|}{ Udora } \\
\hline Winter & 1990 & 2008 & 19 & 0.00 & 0.500 & No Trend \\
\hline Spring & 1990 & 2008 & 19 & 0.21 & 0.583 & No Trend \\
\hline Summer & 1990 & 2008 & 19 & 0.14 & 0.556 & No Trend \\
\hline Fall & 1990 & 2008 & 19 & -0.07 & 0.472 & No Trend \\
\hline \multicolumn{7}{|c|}{ Barrie WPCC } \\
\hline Winter & 1978 & 2004 & 27 & 1.79 & 0.964 & Increasing \\
\hline Spring & 1978 & 2004 & 27 & -0.21 & 0.417 & No Trend \\
\hline Summer & 1978 & 2004 & 27 & 1.13 & 0.870 & No Trend \\
\hline Fall & 1978 & 2004 & 27 & -0.63 & 0.266 & No Trend \\
\hline
\end{tabular}

Based on the results of the test, an increasing trend was seen for the winter season rainfall data at 3 of the 4 stations, Coldwater Warminster, Shanty Bay and Barrie WPCC. No trend was observed for other seasonal rainfall data. 


\section{Analysis for Monthly Statistics}

Analysis of data was further done to obtain the monthly variation of the rainfall. Data were separated individual months for all the years per raingage station. Total precipitation for each month from all the available data was calculated and averaged to obtain the monthly rainfall for the particular station. Mean monthly rainfall for the region was then calculated by Station Average method. The analyzed monthly rainfall data is presented in the Appendix C. Graphical representation of the monthly rainfall is presented in the following figure.

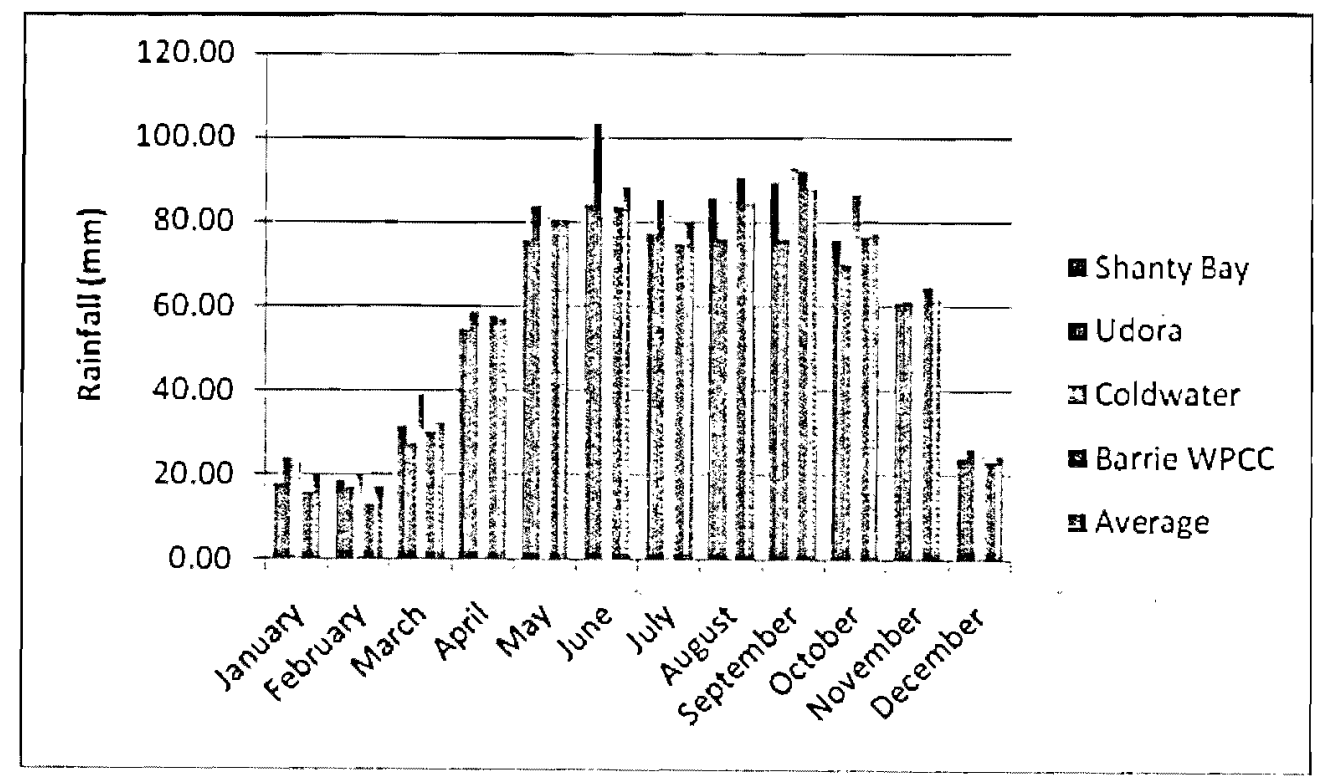

Fig 16: Monthly Rainfall Data 
Table below presents a summary of the analyzed monthly mean rainfall data for all 4 stations.

Table 17: Summary of monthly rainfall data

\begin{tabular}{|c|c|c|c|c|c|c|c|}
\hline \multirow[t]{2}{*}{ Month } & \multicolumn{4}{|c|}{ Total Rainfall (mm) } & \multirow[t]{2}{*}{$\begin{array}{c}\text { Average } \\
(\mathrm{mm})\end{array}$} & \multirow[t]{2}{*}{$\begin{array}{l}\text { Geometric } \\
\text { Mean }\end{array}$} & \multirow[t]{2}{*}{$\begin{array}{l}\text { Standard } \\
\text { Deviation }\end{array}$} \\
\hline & Shanty Bay & Udora & Coldwater & $\begin{array}{l}\text { Barrie } \\
\text { WPCC }\end{array}$ & & & \\
\hline January & 17.93 & 23.67 & 22.69 & 15.83 & 20.03 & 19.76 & 3.76 \\
\hline February & 18.64 & 17.02 & 20.20 & 13.01 & 17.22 & 16.99 & 3.09 \\
\hline March & 31.58 & 27.55 & 39.14 & 30.10 & 32.09 & 31.82 & 4.99 \\
\hline April & 54.72 & 58.55 & 56.06 & 57.76 & 56.77 & 56.75 & 1.72 \\
\hline May & 75.86 & 83.61 & 81.46 & 80.69 & 80.40 & 80.35 & 3.27 \\
\hline June & 84.01 & 103.35 & 81.26 & 83.91 & 88.13 & 87.71 & 10.23 \\
\hline July & 77.22 & 85.47 & 81.88 & 74.84 & 79.85 & 79.75 & 4.75 \\
\hline August & 85.61 & 76.01 & 85.37 & 90.49 & 84.37 & 84.20 & 6.05 \\
\hline September & 89.42 & 76.01 & 92.77 & 92.10 & 87.57 & 87.29 & 7.84 \\
\hline October & 75.70 & 70.23 & 86.39 & 76.40 & 77.18 & 76.97 & 6.73 \\
\hline November & 61.11 & 61.49 & 60.71 & 64.48 & 61.95 & 61.93 & 1.72 \\
\hline December & 24.28 & 26.34 & 24.58 & 23.39 & 24.65 & 24.62 & 1.24 \\
\hline
\end{tabular}

The analyzed monthly data were then ranked in the order of highest to lowest value for all the stations to obtain the wettest and driest month. The following table presents the ranking of the monthly data. 
Table 18: Ranking of Monthly Rainfall data

\begin{tabular}{|c|c|c|c|c|c|c|c|c|c|c|c|}
\hline & \multirow[t]{2}{*}{ Rank } & \multicolumn{2}{|c|}{ Shanty Bay } & \multicolumn{2}{|c|}{ Udora } & \multicolumn{2}{|c|}{ Coldwater } & \multicolumn{2}{|c|}{ Barrie Wpcc } & \multicolumn{2}{|c|}{ Average } \\
\hline & & Month & Rainfall & Month & Rainfall & Month & Rainfall & Month & Rainfall & Month & Rainfall \\
\hline \multirow{12}{*}{ 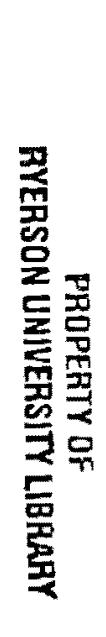 } & 1 & September & 89.42 & June & 103.35 & September & 92.77 & September & 92.10 & June & 88.13 \\
\hline & 2 & August & 85.61 & July & 85.47 & October & 86.39 & August & 90.49 & September & 87.57 \\
\hline & 3 & June & 84.01 & May & 83.61 & August & 85.37 & June & 83.91 & August & 84.37 \\
\hline & 4 & July & 77.22 & September & 76.01 & July & 81.88 & May & 80.69 & May & 80.40 \\
\hline & 5 & May & 75.86 & August & 76.01 & May & 81.46 & October & 76.40 & July & 79.85 \\
\hline & 6 & October & 75.70 & October & 70.23 & June & 81.26 & July & 74.84 & October & 77.18 \\
\hline & 7 & November & 61.11 & November & 61.49 & November & 60.71 & November & 64.48 & November & 61.95 \\
\hline & 8 & April & 54.72 & April & 58.55 & April & 56.06 & April & 57.76 & April & 56.77 \\
\hline & 9 & March & 31.58 & March & 27.55 & March & 39.14 & March & 30.10 & March & 32.09 \\
\hline & 10 & December & 24.28 & December & 26.34 & December & 24.58 & December & 23.39 & December & 24.65 \\
\hline & 11 & February & 18.64 & January & 23.67 & January & 22.69 & January & 15.83 & January & 20.03 \\
\hline & 12 & January & 17.93 & February & 17.02 & February & 20.20 & February & 13.01 & February & 17.22 \\
\hline
\end{tabular}


From the ranking table it is observed that highest average rainfall was recorded in the month of September in three of the 4 stations while it was recorded in the month of June in one of the stations. The highest value for the overall average for all the 4 stations was identified in the month of June. From the results it can be inferred that the month of June is the wettest month for the watershed. This is in line with the seasonal rainfall statistics where summer season was identified as the wettest season followed comparably by the fall season. The average rainfall amount for the month of June was identified to be 88.1 $\mathrm{mm}$.

Similarly, lowest average rainfall was recorded in the month of February in three of the 4 stations while it was recorded in the month of January in one of the stations. The lowest value for the overall average for all 4 stations was identified in the month of February and is considered to be the driest month for the watershed. The average rainfall amount for the month of February was identified to be $17.22 \mathrm{~mm}$.

Mann-Kendall test was performed on the monthly data of all years to establish a trend in monthly variation over the years. The same program, MAKESENS version 1.0 (2002) was used for the test. Similar to the test for yearly and seasonal data, a $95 \%$ level of significance was chosen to conduct the test. The test was performed for all 4 stations and for all the years of available monthly data. Table below summarizes the result obtained from the test.

Table 19: Result of Mann-Kendall test on monthly rainfall data

\begin{tabular}{|c|c|c|c|c|c|c|}
\hline Station & $\begin{array}{l}\text { Starting } \\
\text { Year }\end{array}$ & Last Year & $\begin{array}{l}\text { Number of } \\
\text { readings }\end{array}$ & $\begin{array}{l}\text { Normalized } \\
\text { Test } \\
\text { Statistics Z }\end{array}$ & $\begin{array}{l}\text { Computed } \\
\text { Probability }\end{array}$ & $\begin{array}{l}\text { Trend at } \\
95 \% \text { Level } \\
\text { of } \\
\text { significance }\end{array}$ \\
\hline \multicolumn{7}{|c|}{ Coldwater } \\
\hline $\operatorname{Jan}$ & 1973 & 2009 & 37 & 2.46 & 0.993 & Increasing \\
\hline Feb & 1973 & 2009 & 37 & 1.03 & 0.850 & No Trend \\
\hline Mar & 1973 & 2009 & 37 & -0.82 & 0.205 & No Trend \\
\hline Apr & 1973 & 2009 & 37 & 0.55 & 0.709 & No Trend \\
\hline May & 1973 & 2009 & 37 & 1.40 & 0.919 & No Trend \\
\hline June & 1973 & 2009 & 37 & -0.14 & 0.443 & No Trend \\
\hline July & 1973 & 2009 & 37 & -0.03 & 0.490 & No Trend \\
\hline Aug & 1973 & 2009 & 37 & -2.33 & 0.010 & No Trend \\
\hline Sept & 1973 & 2009 & 37 & -1.45 & 0.073 & No Trend \\
\hline Oct & 1973 & 2009 & 37 & 0.44 & 0.672 & No Trend \\
\hline
\end{tabular}




\begin{tabular}{|c|c|c|c|c|c|c|}
\hline Station & $\begin{array}{l}\text { Starting } \\
\text { Year }\end{array}$ & Last Year & $\begin{array}{l}\text { Number of } \\
\text { readings }\end{array}$ & $\begin{array}{l}\text { Normalized } \\
\text { Test } \\
\text { Statistics Z }\end{array}$ & $\begin{array}{l}\text { Computed } \\
\text { Probability }\end{array}$ & $\begin{array}{l}\text { Trend at } \\
95 \% \text { Level } \\
\text { of } \\
\text { significance }\end{array}$ \\
\hline Nov & 1973 & 2009 & 37 & -0.33 & 0.372 & No Trend \\
\hline Dec & 1973 & 2009 & 37 & 1.58 & 0.943 & No Trend \\
\hline \multicolumn{7}{|c|}{ Shanty Bay } \\
\hline Jan & 1974 & 2009 & 36 & 1.94 & 0.974 & Increasing \\
\hline Feb & 1974 & 2009 & 36 & 1.05 & 0.853 & No Trend \\
\hline Mar & 1974 & 2009 & 36 & -0.95 & 0.170 & No Trend \\
\hline $\mathrm{Apr}$ & 1974 & 2009 & 36 & 0.68 & 0.752 & No Trend \\
\hline May & 1974 & 2009 & 36 & 0.79 & 0.785 & No Trend \\
\hline June & 1974 & 2009 & 36 & 0.59 & 0.721 & No Trend \\
\hline July & 1974 & 2009 & 36 & 1.02 & 0.847 & No Trend \\
\hline Aug & 1974 & 2009 & 36 & -2.36 & 0.009 & No Trend \\
\hline Sept & 1974 & 2009 & 36 & .0 .99 & 0.160 & No Trend \\
\hline Oct & 1974 & 2009 & 36 & 0.40 & 0.654 & No Trend \\
\hline Nov & 1974 & 2009 & 36 & 0.08 & 0.533 & No Trend \\
\hline Dec & 1974 & 2009 & 36 & 1.39 & 0.918 & No Trend \\
\hline \multicolumn{7}{|l|}{ Udora } \\
\hline Jan & 1991 & 2009 & 19 & -0.81 & 0.210 & No Trend \\
\hline Feb & 1991 & 2009 & 19 & 1.23 & 0.890 & No Trend \\
\hline Mar & 1991 & 2009 & 19 & 0.81 & 0.790 & No Trend \\
\hline Apr & 1991 & 2009 & 19 & -0.14 & 0.444 & No Trend \\
\hline May & 1991 & 2009 & 19 & 1.61 & 0.946 & No Trend \\
\hline June & 1991 & 2009 & 19 & 0.70 & 0.758 & No Trend \\
\hline July & $\overline{1991}$ & 2009 & 19 & 0.14 & 0.556 & No Trend \\
\hline Aug & 1991 & 2009 & 19 & -1.12 & 0.131 & No Trend \\
\hline Sept & 1991 & 2009 & 19 & -1.12 & 0.131 & No Trend \\
\hline Oct & 1991 & 2009 & 19 & 0.28 & 0.610 & No Trend \\
\hline Nov & 1991 & 2009 & 19 & 0.00 & 0.500 & No Trend \\
\hline Dec & 1991 & 2009 & 19 & 1.47 & 0.929 & No Trend \\
\hline \multicolumn{7}{|c|}{ Barrie Wpcc } \\
\hline $\operatorname{Jan}$ & 1979 & 2005 & 27 & 1.26 & 0.895 & No Trend \\
\hline Feb & 1979 & 2005 & 27 & 1.14 & 0.872 & No Trend \\
\hline Mar & 1979 & 2005 & 27 & -0.75 & 0.226 & No Trend \\
\hline$\overline{A p r}$ & 1979 & 2005 & 27 & -0.79 & 0.214 & No Trend \\
\hline May & 1979 & 2005 & 27 & 0.71 & 0.761 & No Trend \\
\hline June & 1979 & 2005 & 27 & 0.96 & 0.831 & No Trend \\
\hline July & 1979 & 2005 & 27 & 0.21 & 0.583 & No Trend \\
\hline Aug & 1979 & 2005 & 27 & -0.46 & 0.323 & No Trend \\
\hline Sept & 1979 & 2005 & 27 & -0.38 & 0.354 & No Trend \\
\hline Oct & 1979 & 2005 & 27 & -1.04 & 0.149 & No Trend \\
\hline Nov & 1979 & 2005 & 27 & -0.44 & 0.331 & No Trend \\
\hline Dec & 1979 & 2005 & 27 & 0.58 & 0.720 & No Trend \\
\hline
\end{tabular}


Based on the results of the test, an increasing trend was seen for the month of January in two of the 4 raingage stations. Coldwater Warminster and Shanty Bay showed an increasing trend in the rainfall data for the month of January. No trend was observed for other monthly rainfall data. 


\section{Conclusion}

Hourly and Daily rainfall data from 13 raingage stations around Lake Simcoe area were analyzed to characterize the rainfall contributing to Lake Simcoe watershed. Analysis was done to characterize the data into event, monthly, seasonal and annual statistics and thereby to determine the driest, wettest and average annual rainfall. The available data ranged from May 1968 to November 2003 for hourly data and February 1957 to May 2010 for daily rainfall data. However it was observed that the time interval for the available data was not consistent among the raingage stations. The analysis was started with hourly data to characterize the rainfall event. A program was developed in Excel VBA to separate the rainfall into different events with $6 \mathrm{hr}, 12 \mathrm{hr}$ and $24 \mathrm{hr}$ inter-event time definition. Due to insufficient amount of available data the characterization of rainfall event was discontinued. Nevertheless a program and framework of analysis has been developed under this project work which can be utilized when the data are available.

Daily data were analyzed for monthly, seasonal and yearly mean rainfall values and to obtain the driest, wettest and average annual rainfall statistics. The analysis of data revealed that only 4 stations contained data for an approximate period of 20 years and only these 4 stations were chosen for analysis of the rainfall. For the analysis of yearly data, the data were first separated into hydrological year which is from $1^{\text {st }}$ June to $31^{\text {st }}$ March. The hydrological year was chosen to be consistent with the past studies on phosphorous loading for Lake Simcoe such as "Report on the Phosphorous Load on Lake Simcoe, 2004-2007". For the seasonal analysis the yearly data were separated into 4 seasons. Winter season comprised of December, January and February; spring comprised of March, April and May; summer comprised of June, July and August and fall comprised of September, October and November. For the monthly analysis, the obtained data were separated into 12 calendar months.

Mann-Kendall test was performed on the data to establish a trend in the rainfall records. MAKESENS version 1.0 (2002), an excel program developed by Finnish Metrological Institute - "Conduct Mann-Kendall test and Sen's Slope estimate for the Trend of Annual 
Data" was used to conduct the test. A $95 \%$ level of significance was chosen to conduct the test.

The following conclusions were derived based on the analysis of verified daily data -

\section{Hydrological year}

- Highest rainfall was recorded at different raingage stations in different hydrological year. However, the average value obtained from the cumulative data of all the raingage stations showed that overall highest rainfall for the watershed was in the hydrological year 1995-1996 and is considered to be the wettest hydrological year. The mean yearly rainfall amount for hydrological year 19951996 was $871.8 \mathrm{~mm}$.

- Different raingage stations recorded the lowest rainfall in different hydrological years. However, based on the average data of all the stations, it is seen that hydrological year 1991-1992 was the driest year for the watershed with only $525.7 \mathrm{~mm}$ of rainfall.

- The average annual rainfall for the watershed is identified as $709.5 \mathrm{~mm}$.

- Based on Mann-Kendall test results no trend was observed for the hydrological yearly rainfall.

\section{Seasonal}

- Highest rainfall was recorded in the summer season for all the 4 raingage stations. The summer season is considered the wettest season for the watershed with an average rainfall of $248.9 \mathrm{~mm}$. However, fall season also has comparable amount of rainfall with an average of $236.4 \mathrm{~mm}$.

- Lowest rainfall was recorded in the same season for all the 4 raingage stations. Winter is the driest season for the watershed with only an average of $59.8 \mathrm{~mm}$ rainfall.

- Based on Mann-Kendall test results, an increasing trend was seen for the winter season rainfall data at 3 of the 4 stations, Coldwater Warminster, Shanty Bay and Barrie WPCC. No trend was observed for other seasonal rainfall data. 


\section{Monthly}

- Highest average rainfall was recorded in the month of September in three of the 4 stations while it was recorded in the month of June in one of the stations. However, the highest value for the overall average for all the 4 stations was identified in the month of June and is considered to be the wettest month for the watershed. This is in line with the seasonal rainfall statistics where summer season was identified as the wettest season followed comparably by the fall season. The average rainfall amount for the month of June was identified to be $88.1 \mathrm{~mm}$.

- Lowest average rainfall was recorded in the month of February in three of the 4 stations while it was recorded in the month of January in one of the stations. The lowest value for the overall average for all 4 stations was identified in the month of February and is considered to be the driest month for the watershed. The average rainfall amount for the month of February was identified to be $17.22 \mathrm{~mm}$.

- Based on the results of the Mann-Kendall test, a slight increasing trend was seen for the month of January in two of the 4 raingage stations. Coldwater Warminster and Shanty Bay showed an increasing trend in the rainfall data for the month of January. No trend was observed for other monthly rainfall data. 


\section{Appendix A}

Excel VBA Program for analysis of $\mathbf{2 4}$ hour Inter-event time definition 
Option Explicit

Sub methodo

Sheets(Array("s 1")).Select

Sheets("sl").Activate

Range("A1").Select

Dim i As Integer

Dim hourofonrainfall As Integer

Dim count As Integer

Dim zerofallcount As Integer

Dim starthour As Integer

Dim endhour As Integer

Dim $\mathrm{j}$ As Integer

Dim syear As Integer

Dim smonth As Integer

Dim sday As Integer

Dim eyear As Integer

Dim emonth As Integer

Dim eday As Integer

Dim volume As Integer

Dim peakIntensity As Integer

Dim writeline As Integer

Dim k As Integer

Dim m As Integer

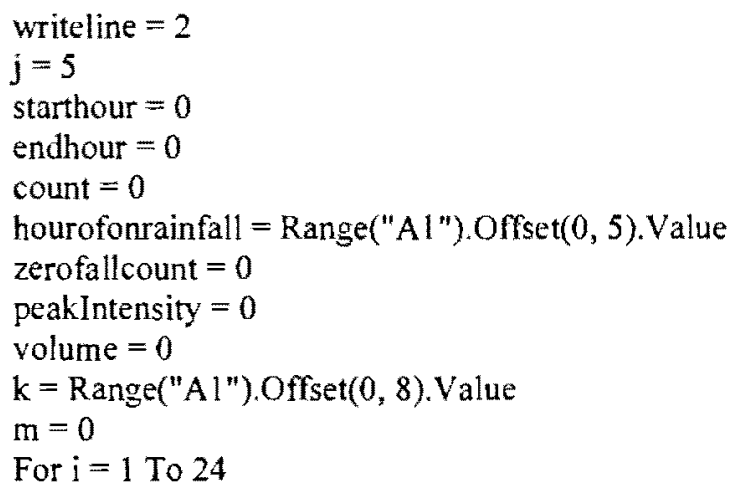

If (Range("Al"). Offset $(j, i+2)$.Value) $>0$ Then count $=$ count +1

If (peakIntensity < Range("A1").Offset $(j, i+2)$.Value) Then peakIntensity $=$ Range(" $\mathrm{Al}$ "). Offset $(\mathrm{j}, \mathrm{i}+2)$.Value

End If

volume $=$ volume + Range $(" A 1 ")$. Offset $(j, i+2)$. Value

zerofallcount $=0$

If $($ count $=1)$ Then

starthour $=\mathrm{i}$

syear = Range("A1").Offset $(j, 0)$.Value smonth = Range("A1").Offset(, 1$)$.Value sday = Range("A1"),Offset $(j, 2)$, Value

End If

Else

zerofallcount $=$ zerofallcount +1

If (zerofallcount $=$ hourofonrainfall) Then 


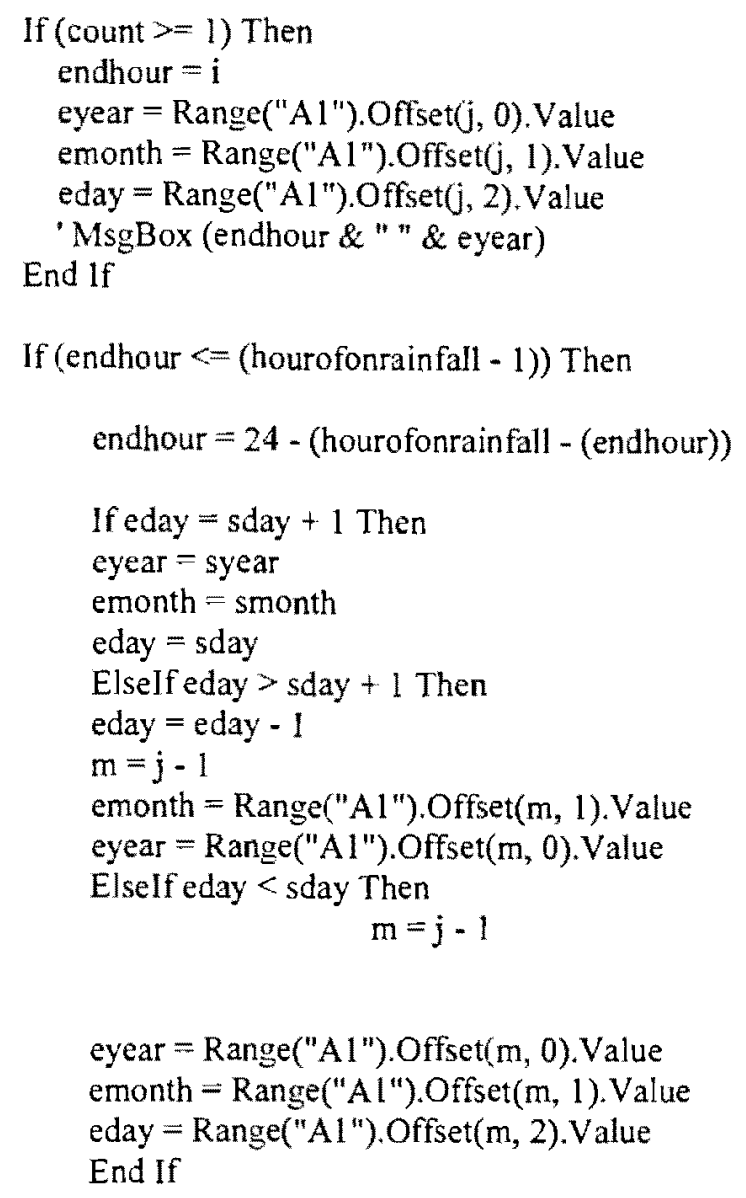

\section{Else \\ endhour = endhour - hourofonrainfall}

End If

'If (starthour = endhour And sday = eday) Then

' endhour $=$ endhour +0

'End If

If (count $>=1$ ) Then

Dim $x$ As Integer

$x=27$

Range("A1").Offset(writeline, $x)=$ syear

Range("A1").Offset(writeline, $x+1)=$ smonth

Range("A1"). Offset(writeline, $x+2)=$ sday

Range("A1").Offset(writeline, $x+3$ ) = starthour

$\&$ ":00"

Range("A1"),Offset( writeline, $x+4)=$ syear \& " " \& smonth \& "/" \& sday \& " \& starthour

$\& ": 00^{\prime \prime}$

Range("A1"),Offset(writeline, $x+5)=$ eyear

Range("A1"). Offset(writeline, $x+6)=$ emonth

Range("A1").Offset(writeline, $x+7)=$ eday

Range("A1"). Offset(writeline, $x+8)=$ endhour

Range("A1").Offset(writeline, $x+9)=$ eyear \& "/" \& emonth \& "/" \& eday \& " " \& endhour

Range("Al"), Offset(writeline, $x+10)=$ DateDiff("h", Range("Al").Offset(writeline, $x+4)$. 
Value, Range("Al").Offset(writeline, $x+9)$.Value)

'Range("A1"). Offset(writeline, $x+11)="$ "

Range("Al").Offset(writeline, $x+12)=$ volume $/ 10$

'Range("A1").Offset(writeline, $x+13)=$ ""

Range("A1").Offset(writeline, $x+14)=$ peakIntensity $/ 10$

writeline $=$ writeline +1

'MsgBox (syear \& "," \& smonth \& "," \& sday \& "," \& starthour \& "volume" \& volume \& "peakIntensity" \& peakIntensity)

"MsgBox (eyear \& "," \& emonth \& "," \& eday \& "," \& endhour)

volume $=0$

peaklntensity $=0$

count $=0$

End If

\section{End If}

\section{End If}

If $i=24$ And $j<k$ Then

$\mathrm{i}=\mathbf{0}$

$\mathrm{j}=\mathrm{j}+1$

' MsgBox $(" \mathrm{j}=" \& \mathrm{j})$

' $\operatorname{MsgBox}(" \mathrm{i}="$ \& $\mathrm{i})$

End If

Next i

End Sub 


\section{Appendix B}

\section{Verified Daily Rainfall Arranged Per Hydrological Year}




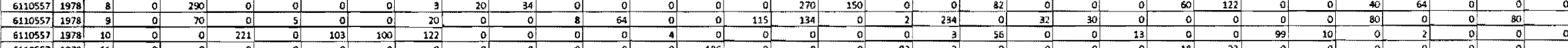

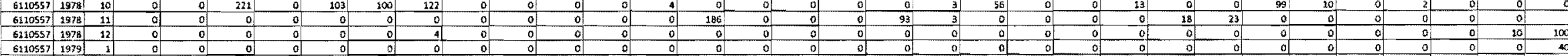

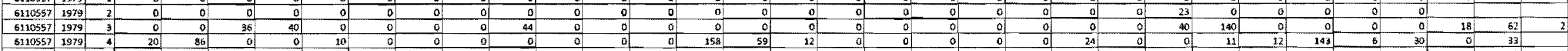

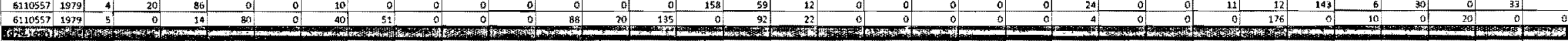

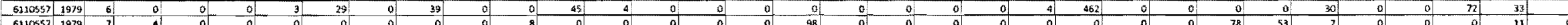

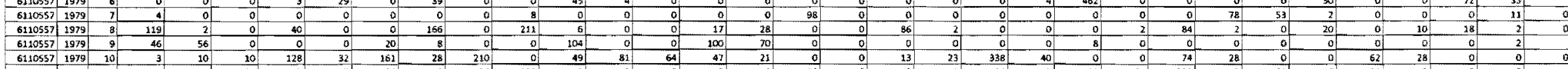

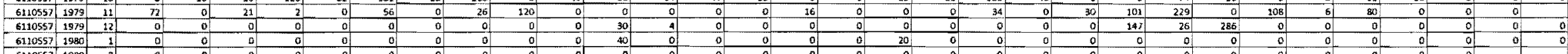

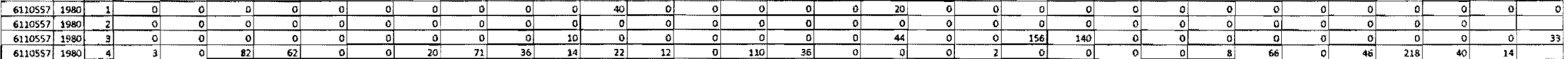

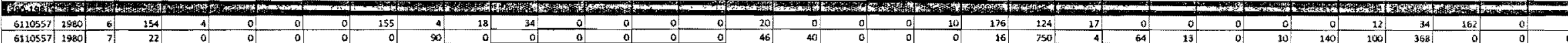

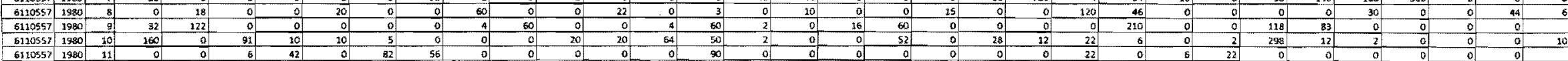

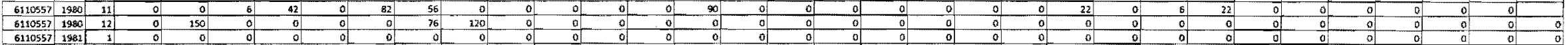

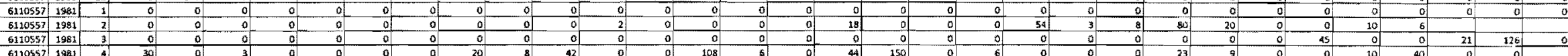

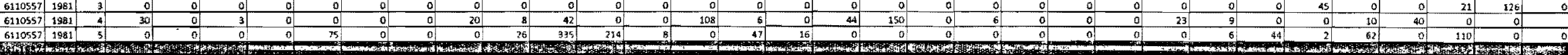

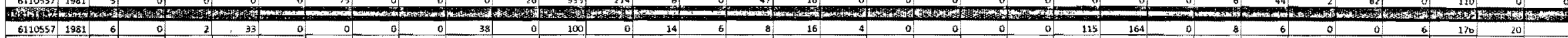

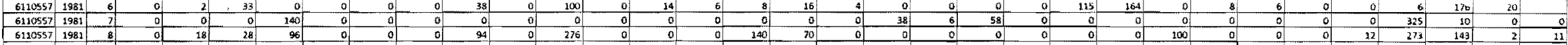

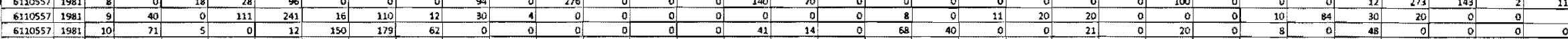

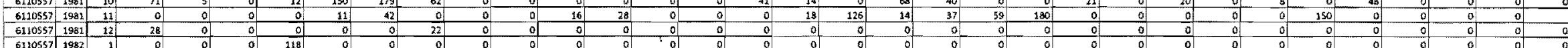

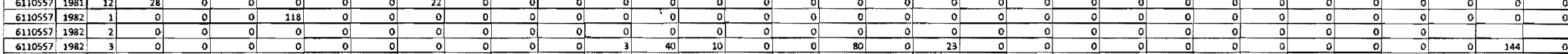

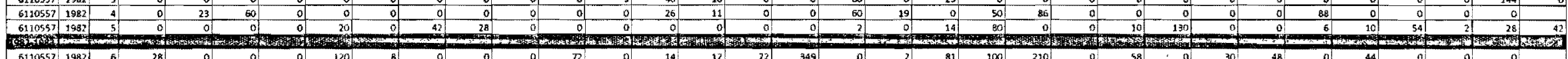

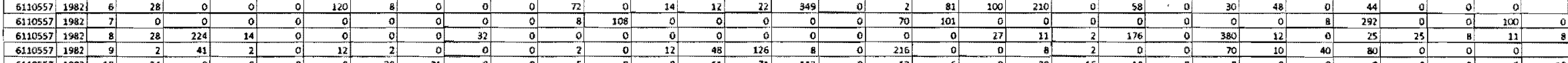

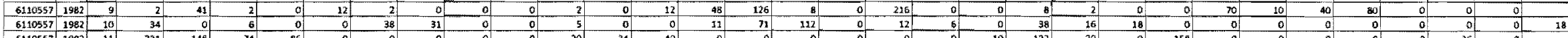

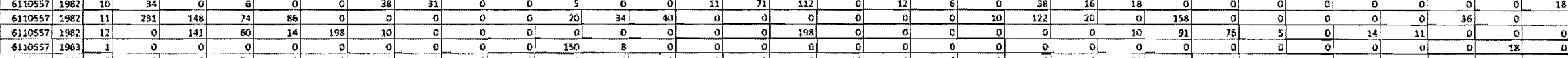

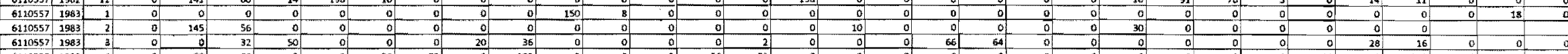

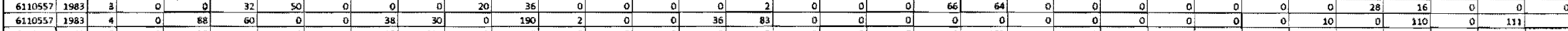

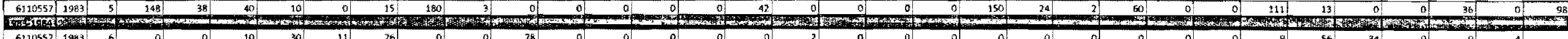

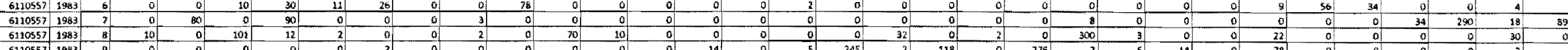

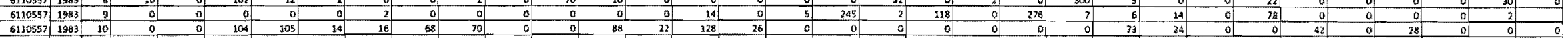

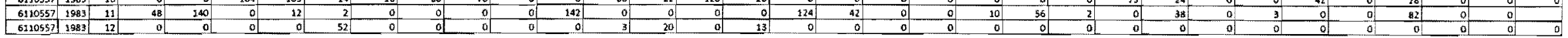




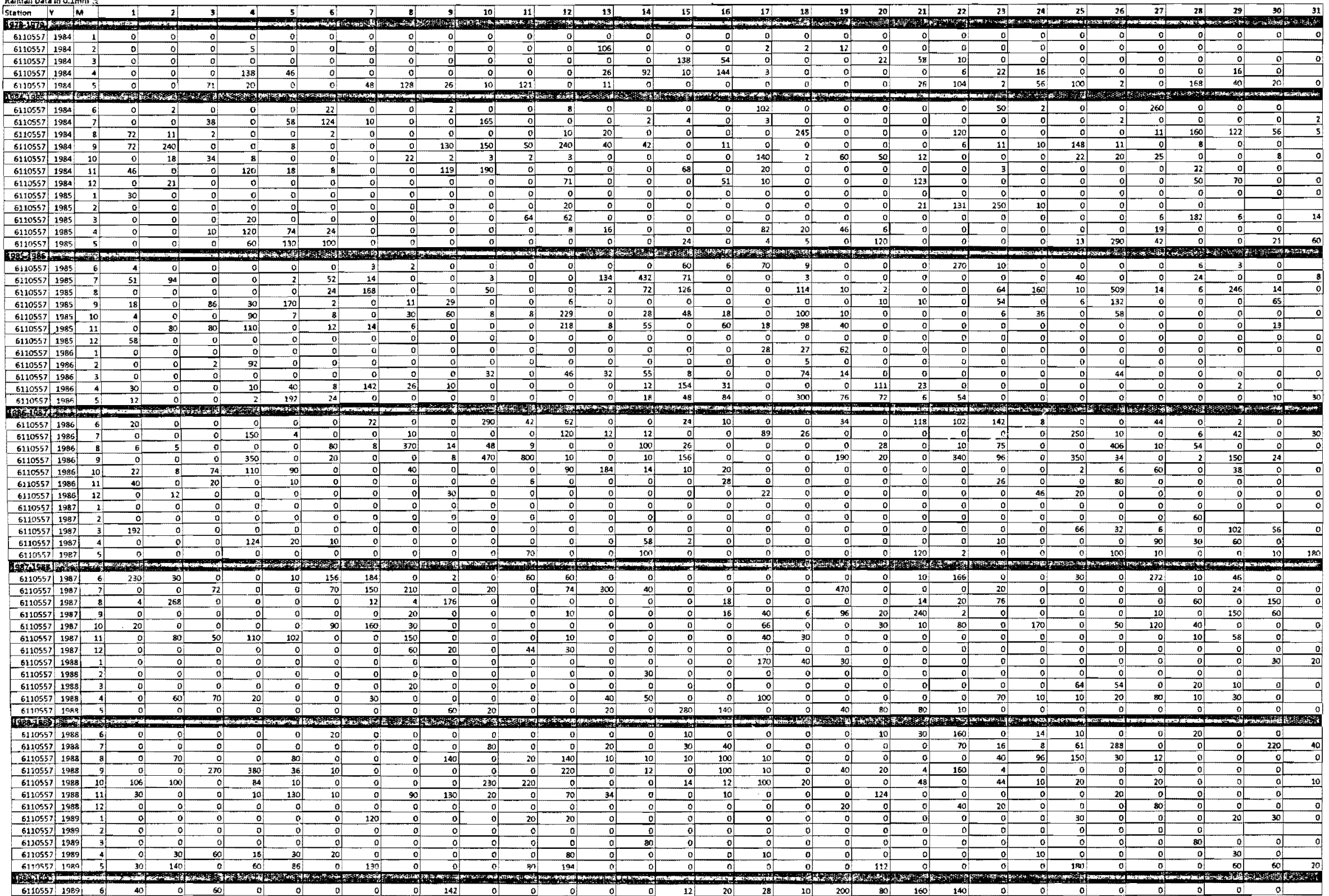


Garrie WPCC

Hydrotesical reer

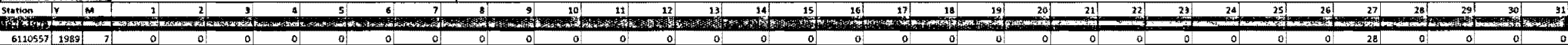

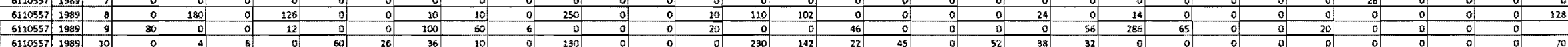

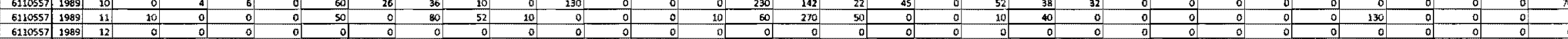

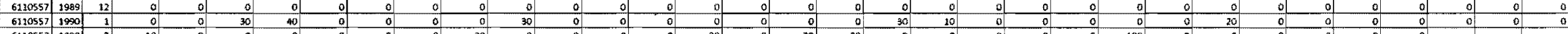

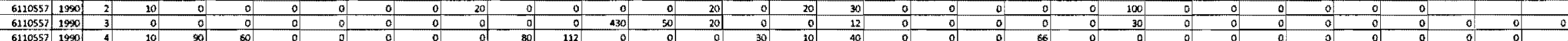

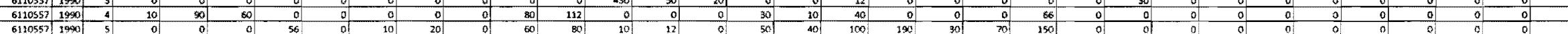

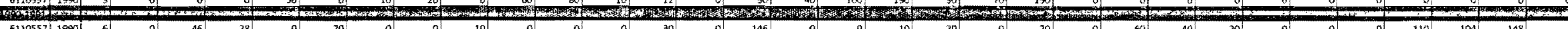

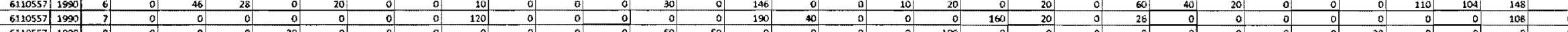

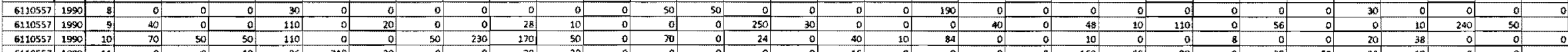

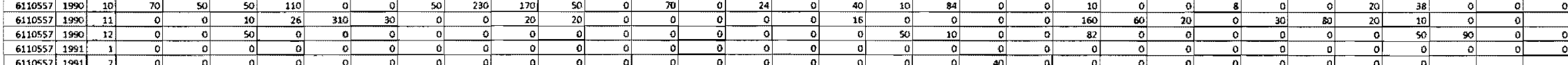

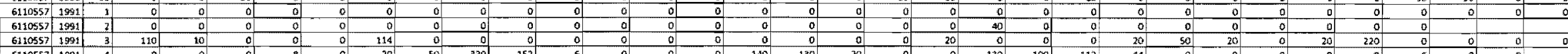

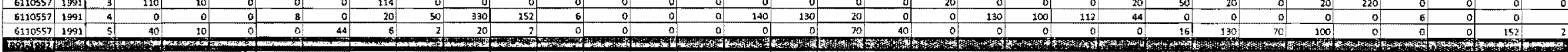

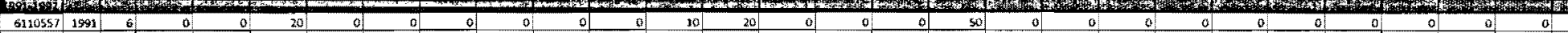

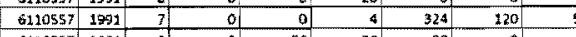

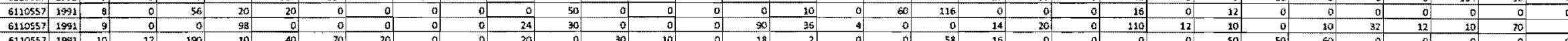

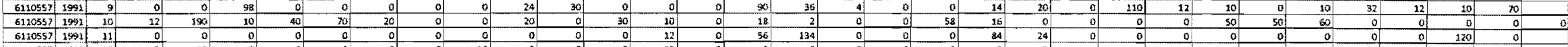

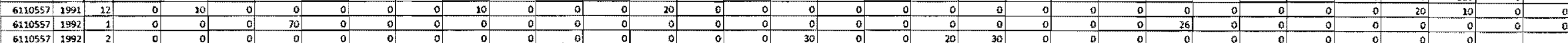

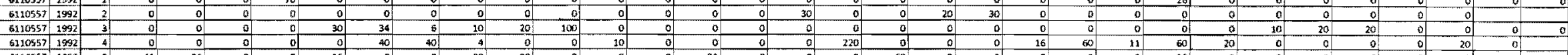

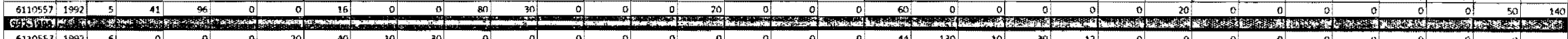

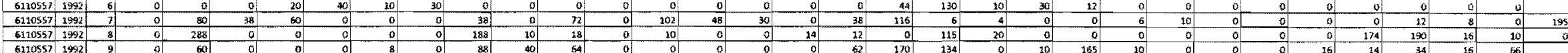

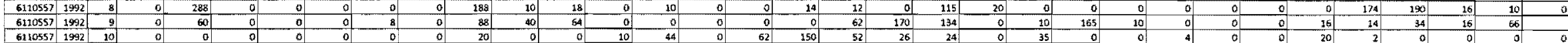

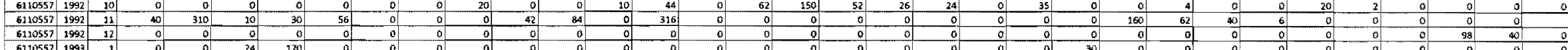

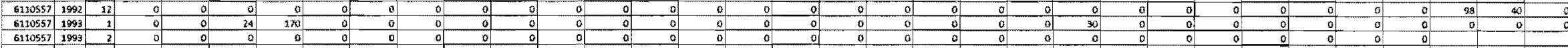

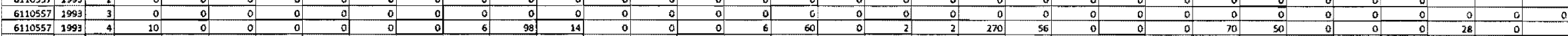

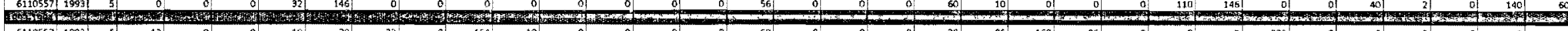

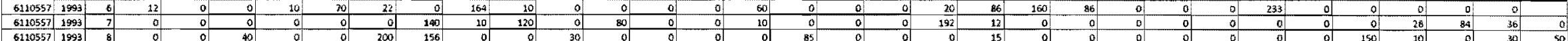

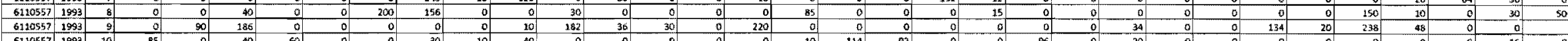

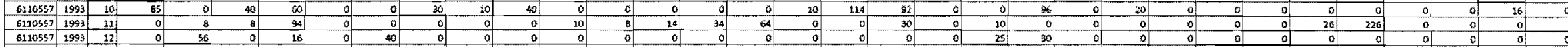

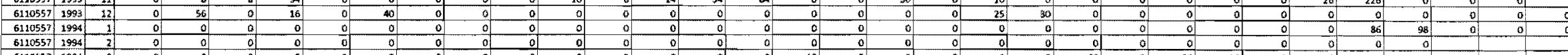

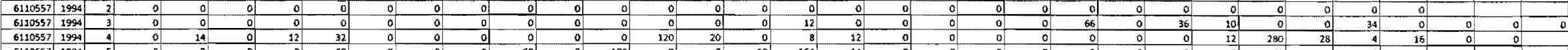

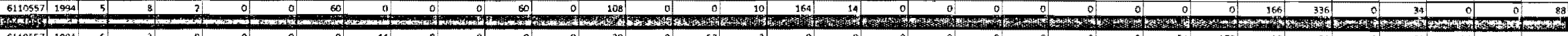

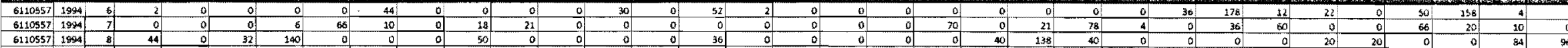

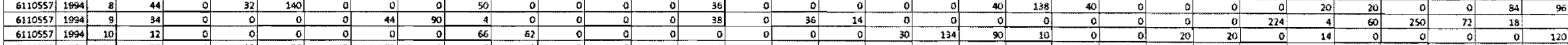

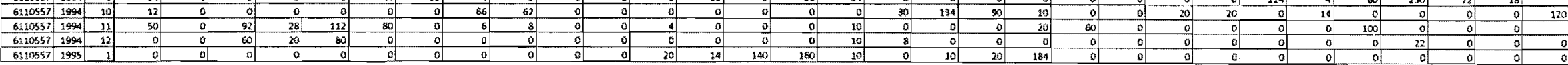




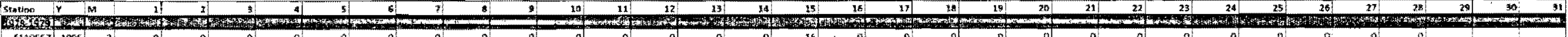

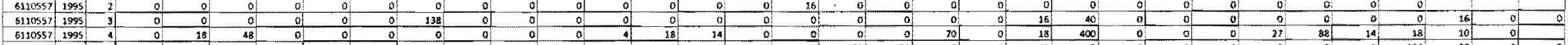

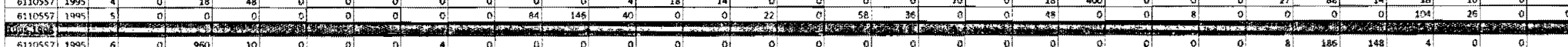

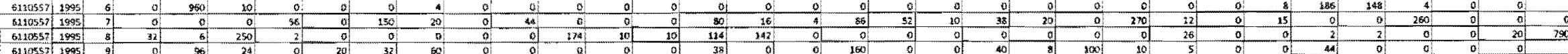

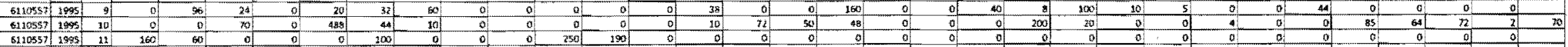

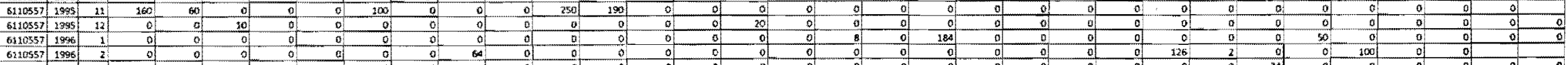

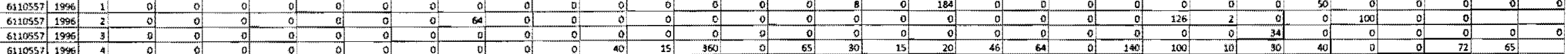

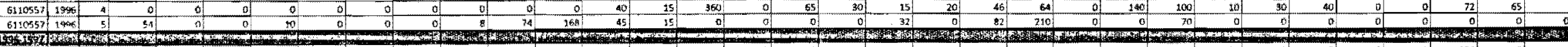

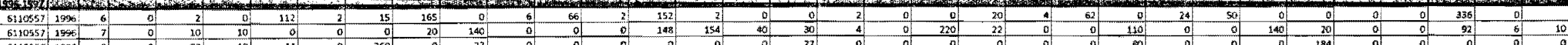

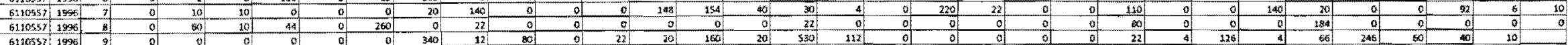

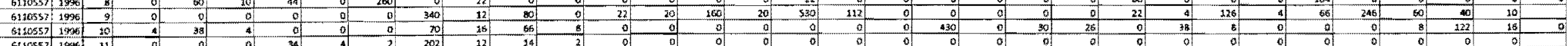

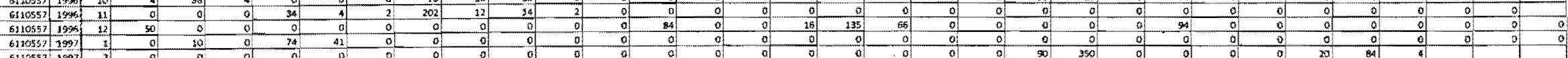

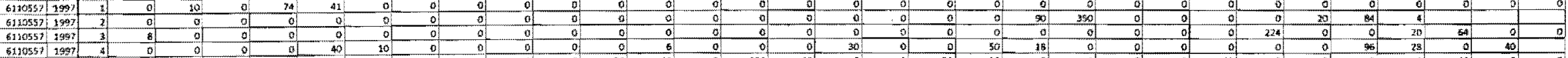

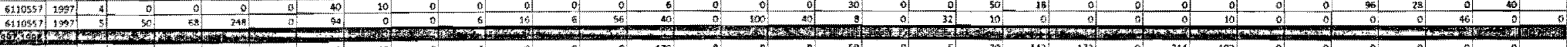

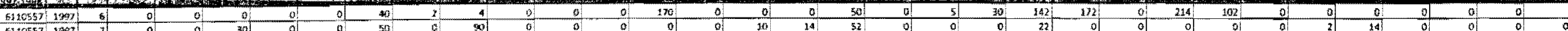

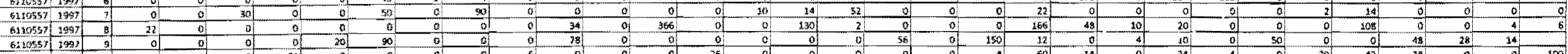

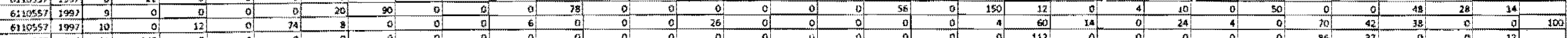

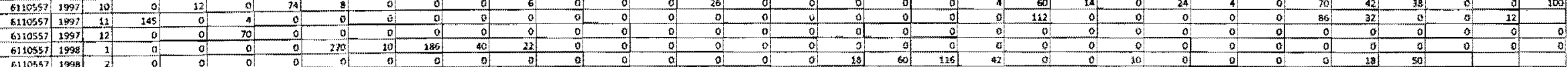

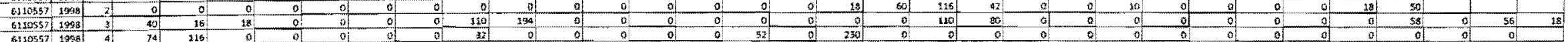

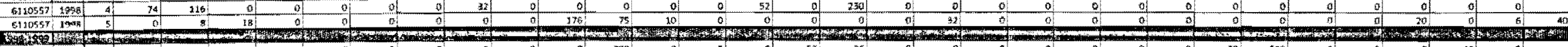

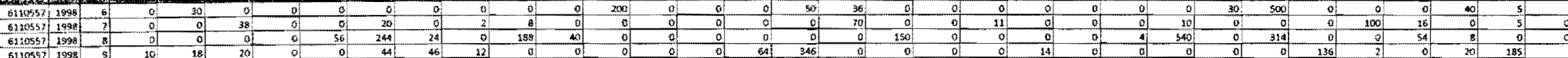

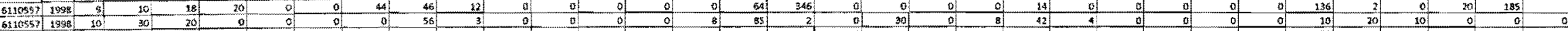

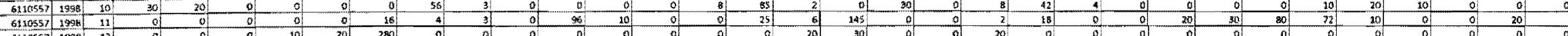

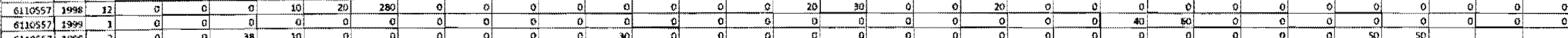

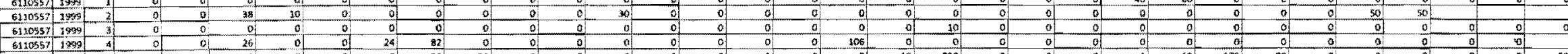

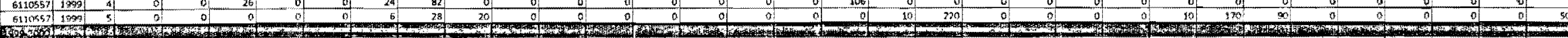

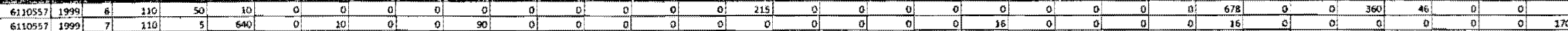

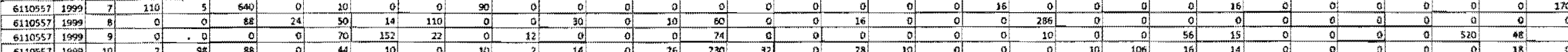

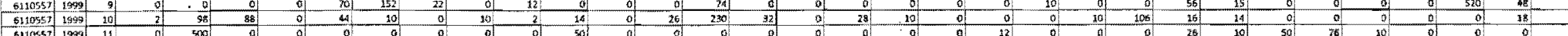

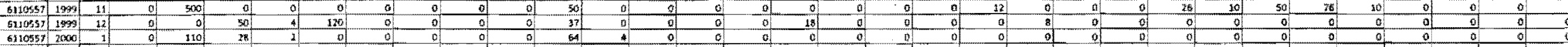

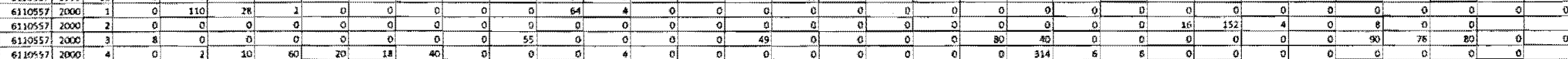

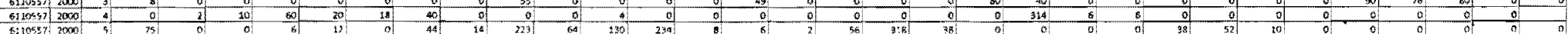

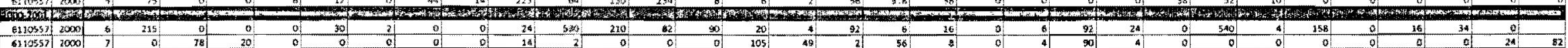




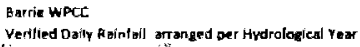

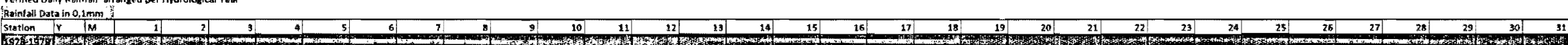

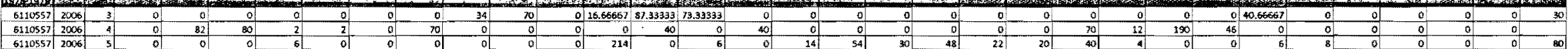

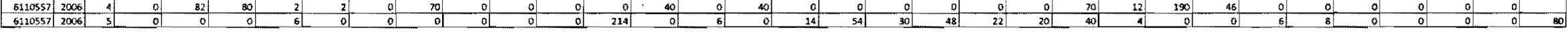




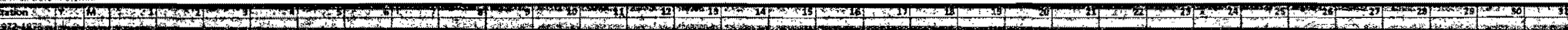

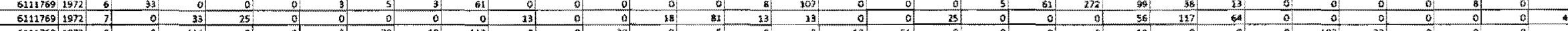

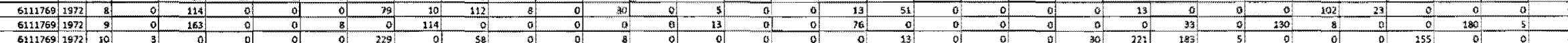

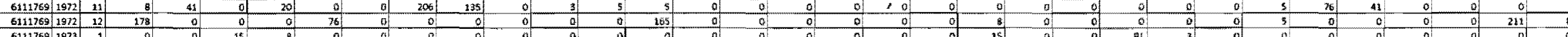

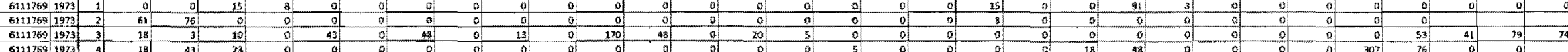

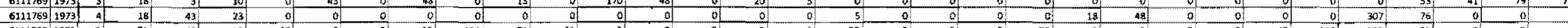

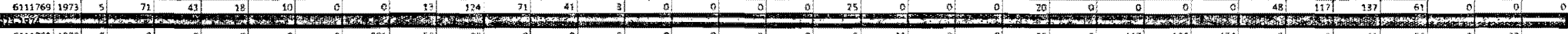

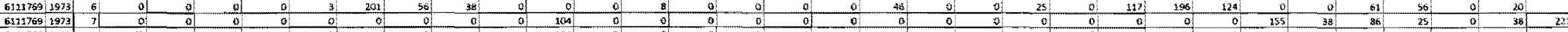

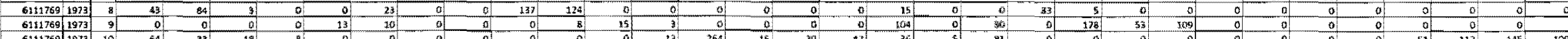

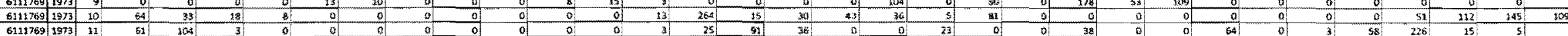

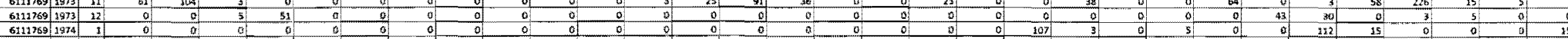

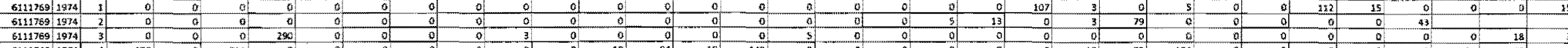

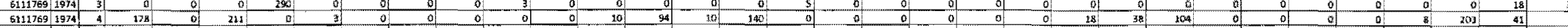

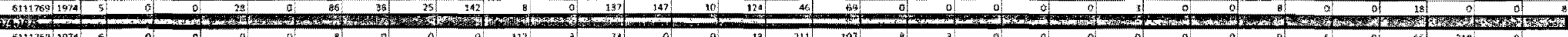

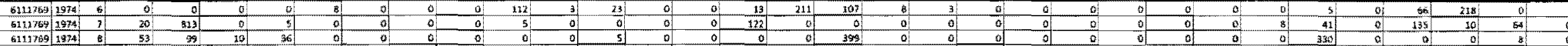

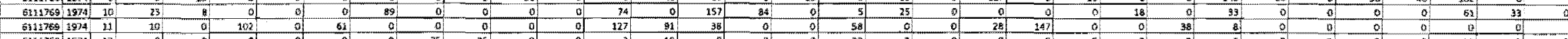

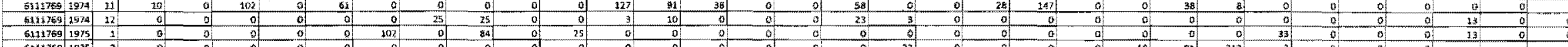
6217961955 6

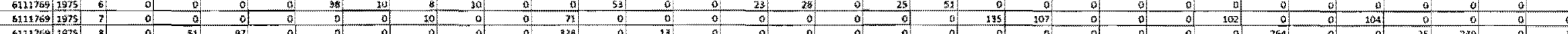

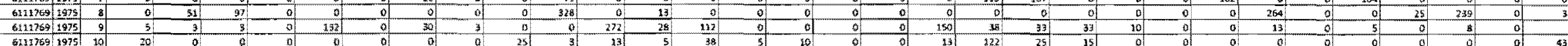

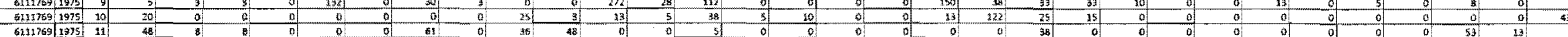

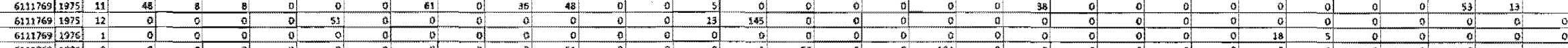

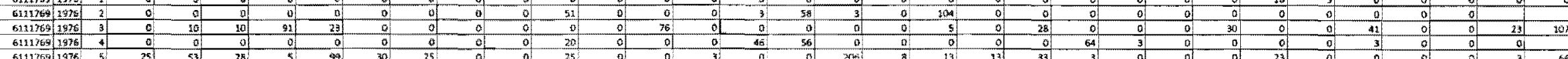

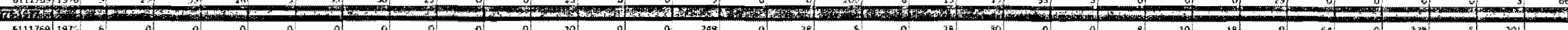

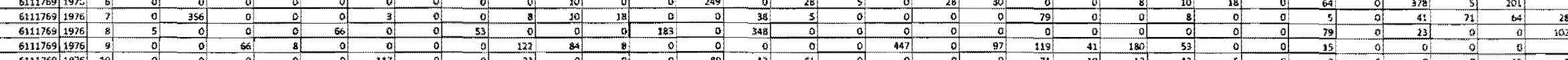

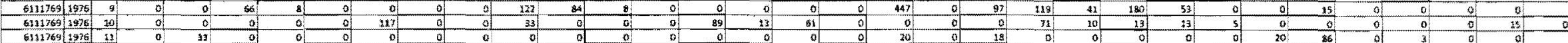

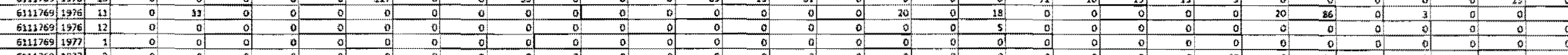

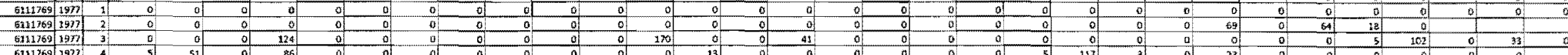

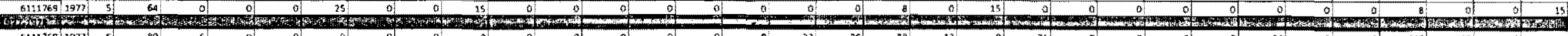

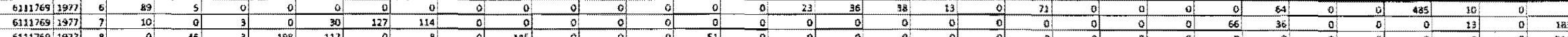

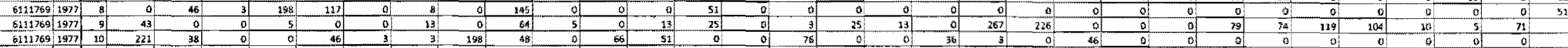

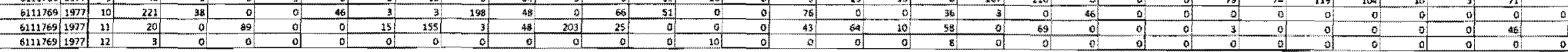




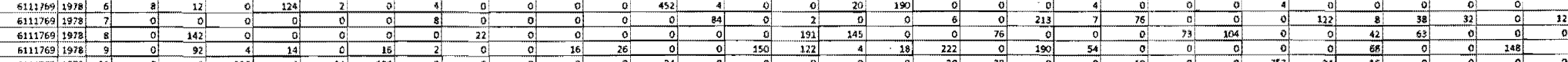

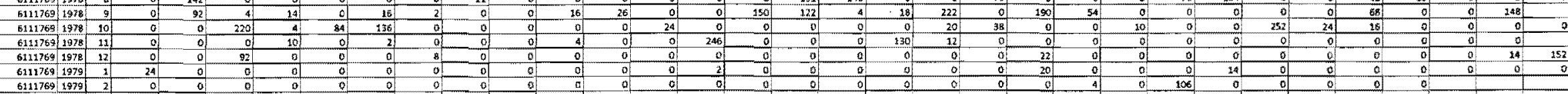

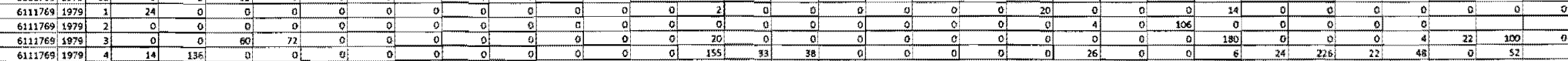

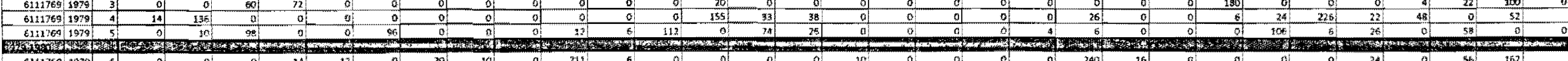

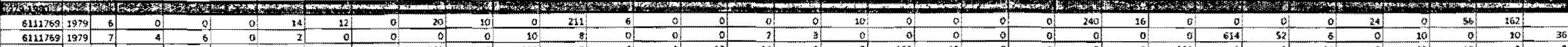

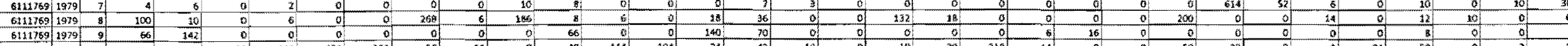

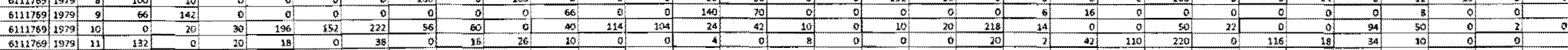

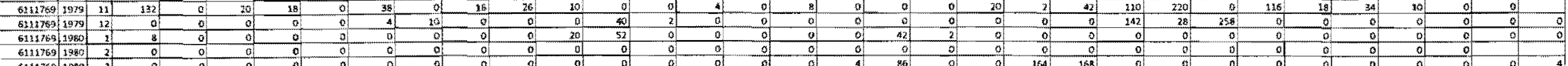

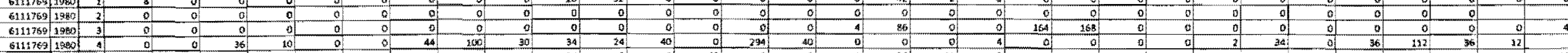

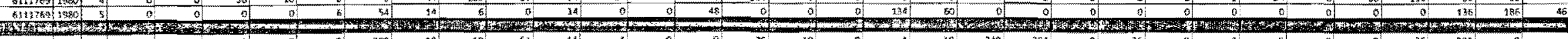

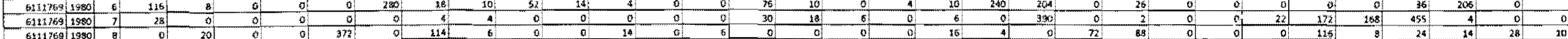

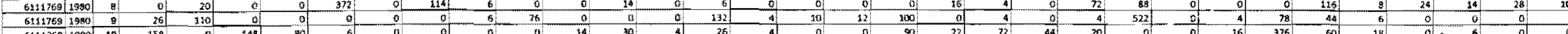

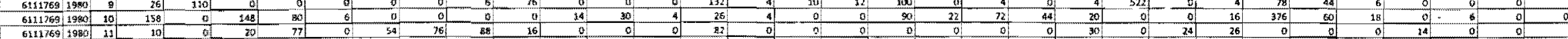

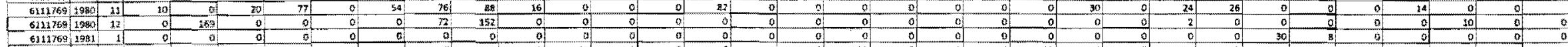

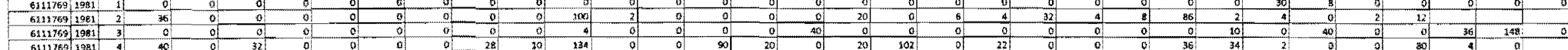

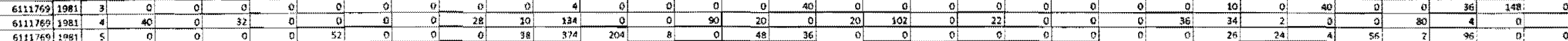

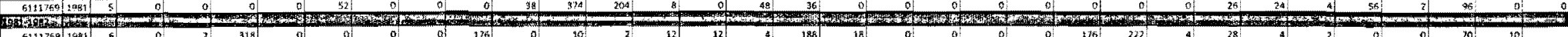

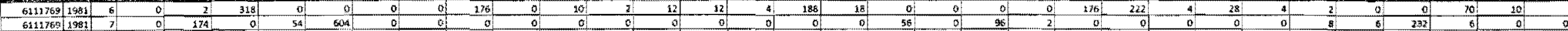

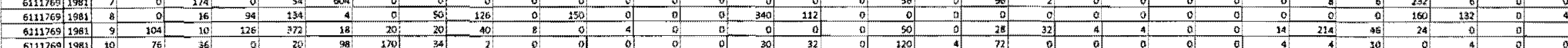

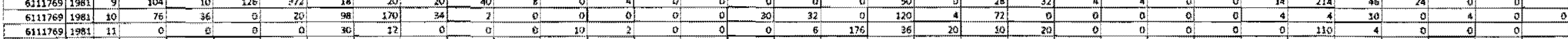

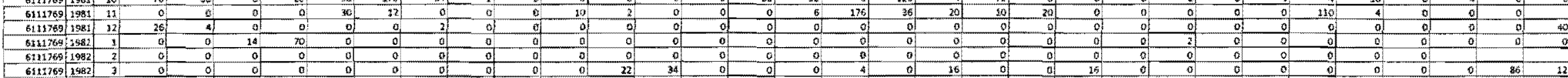

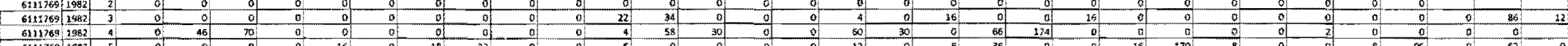

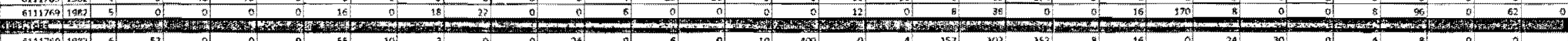

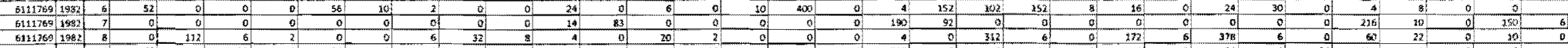

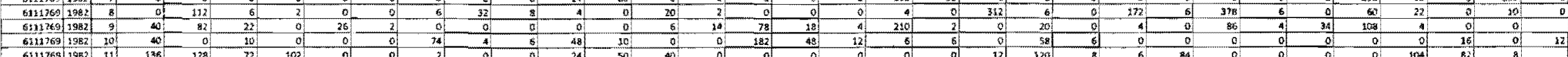

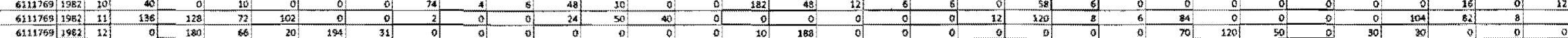

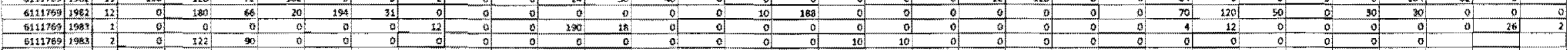

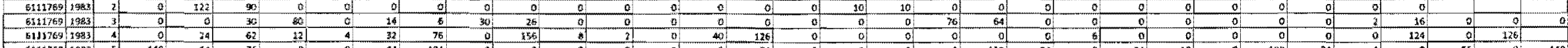
(6)

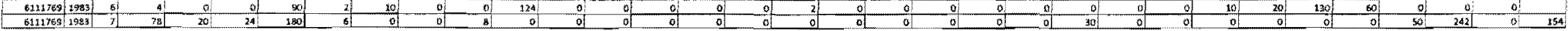




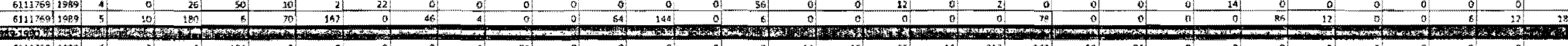

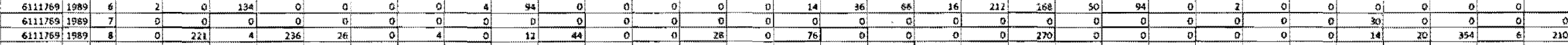

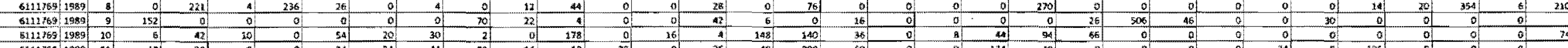

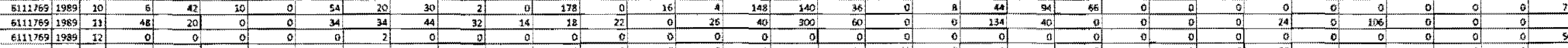

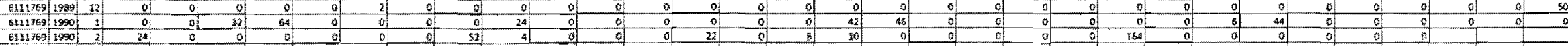

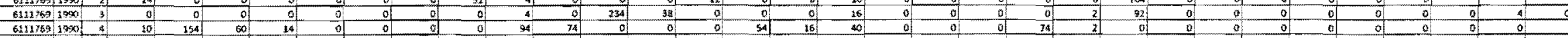

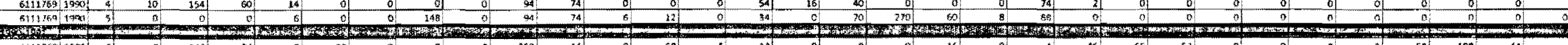

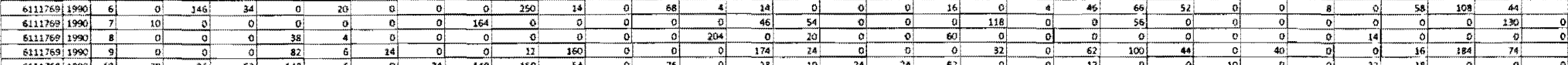

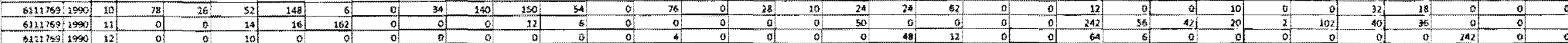

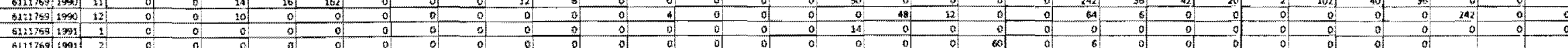

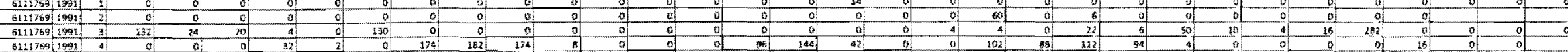

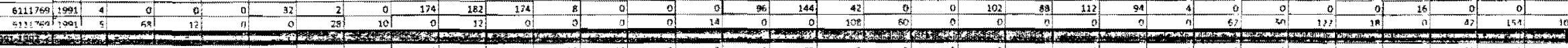

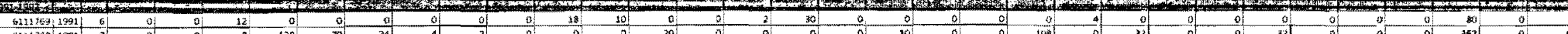

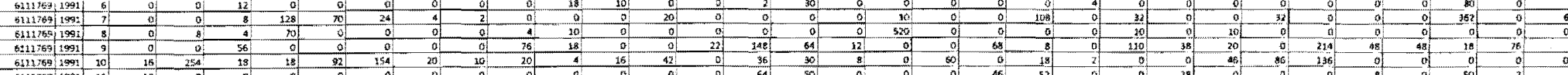

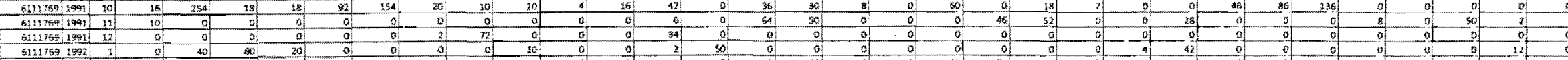

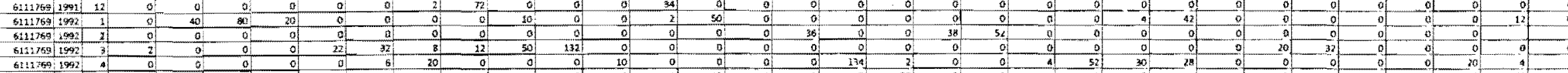

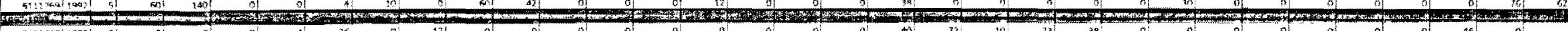

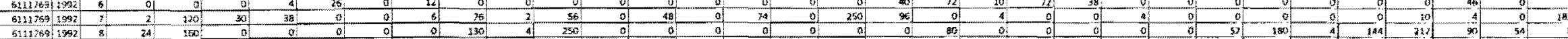

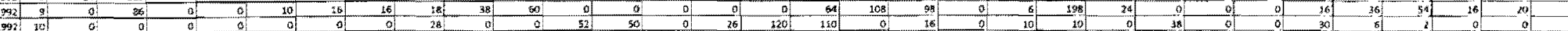

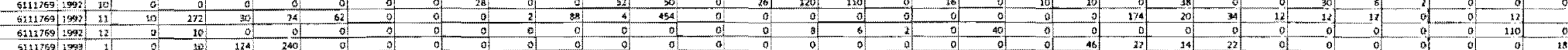

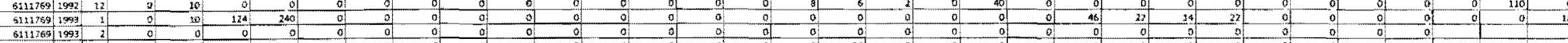

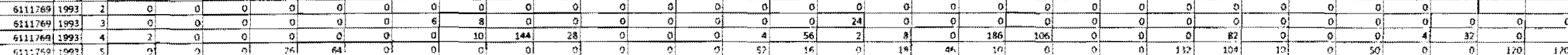

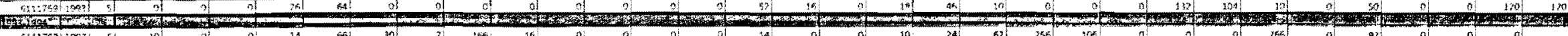

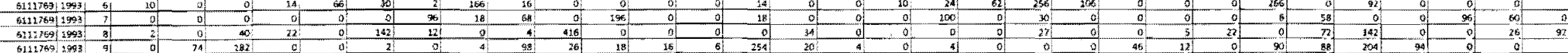

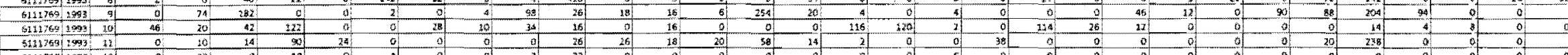

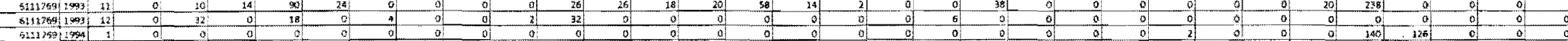

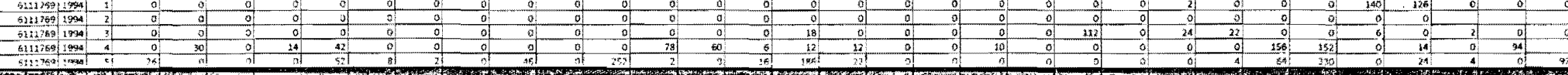

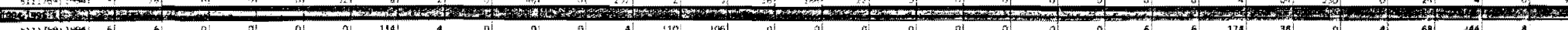

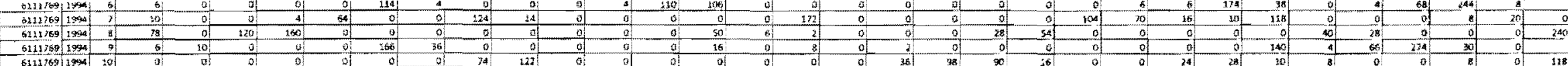


Coldwater Wryminter

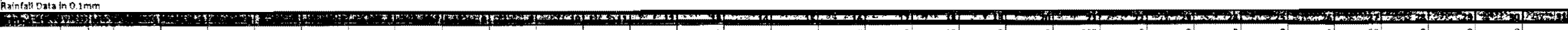

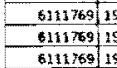

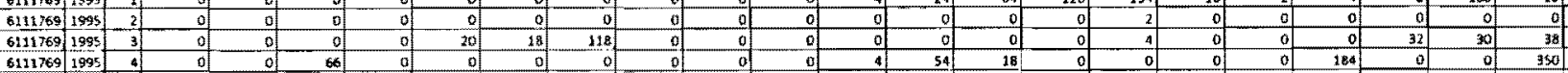

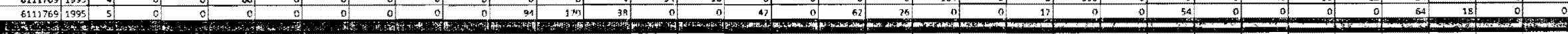

6.611769 1995

60.11269 .1996

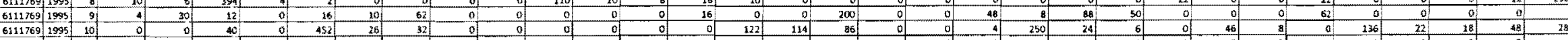

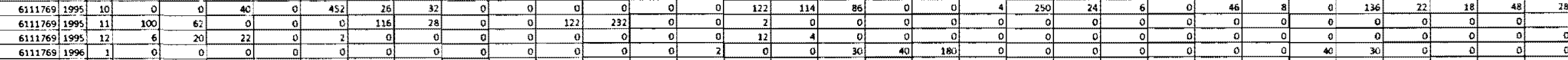

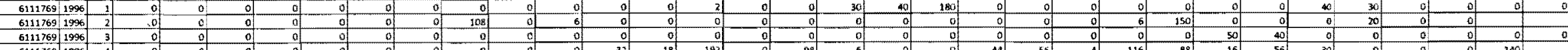

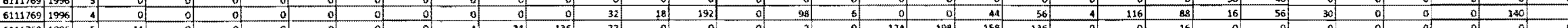

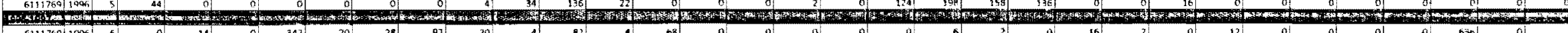

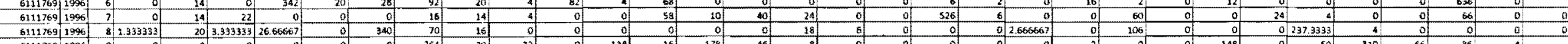

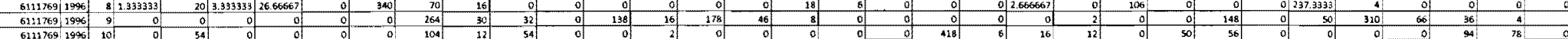

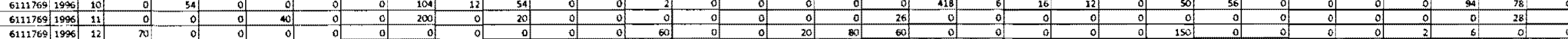

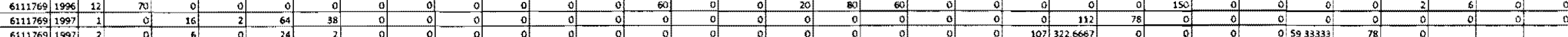

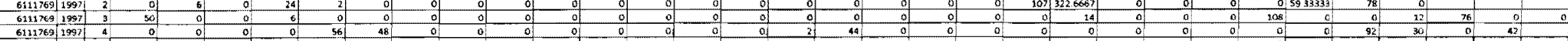

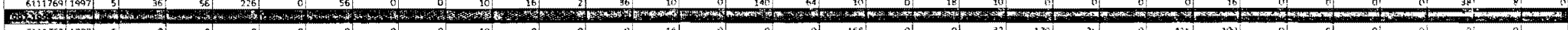

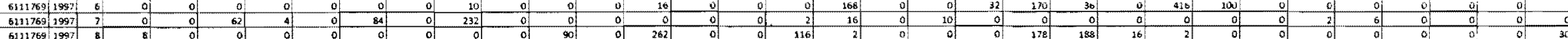

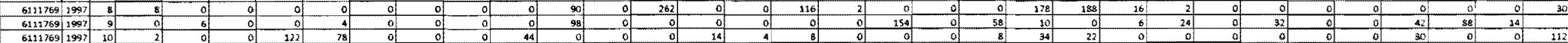

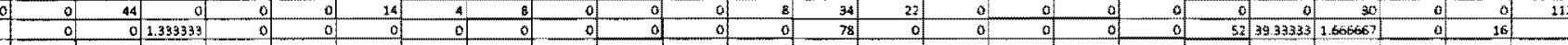

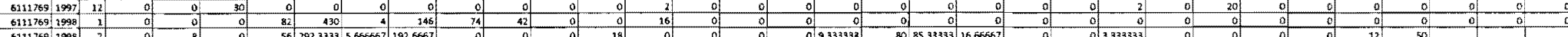

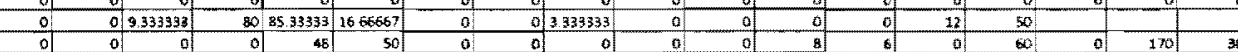

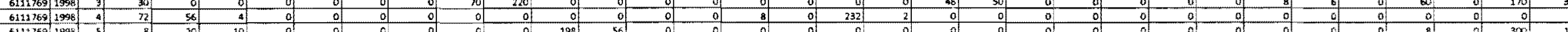
Wh

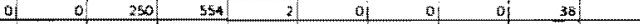

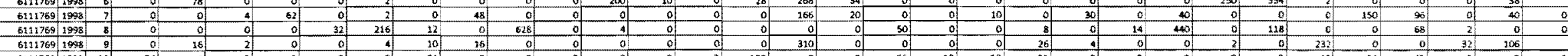

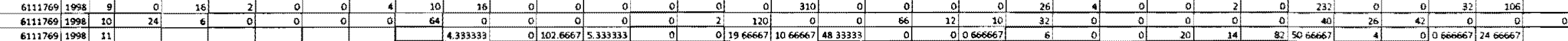

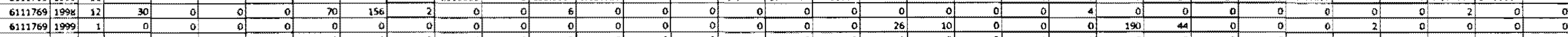

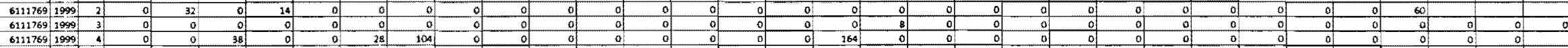

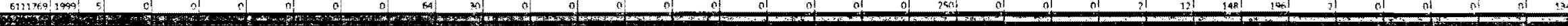

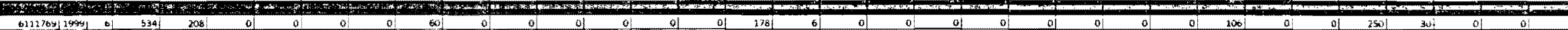

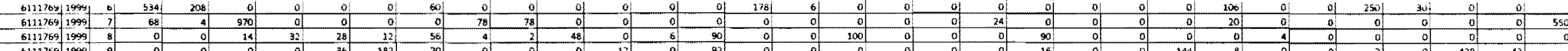
$20-36-183-20$

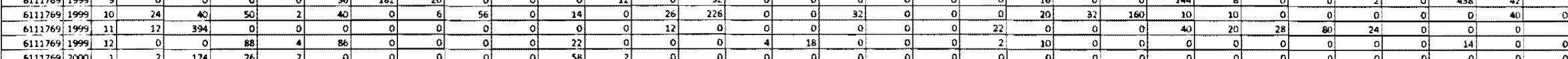

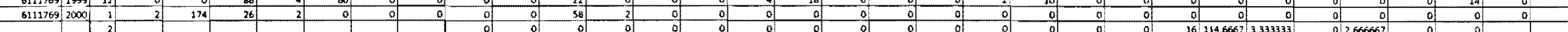

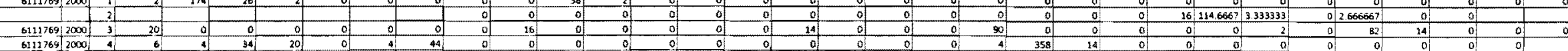
6. 


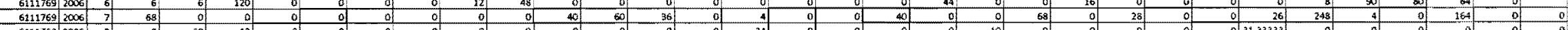

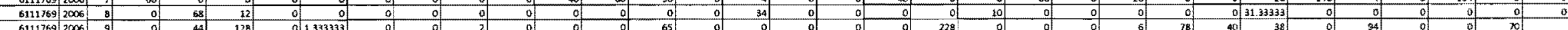

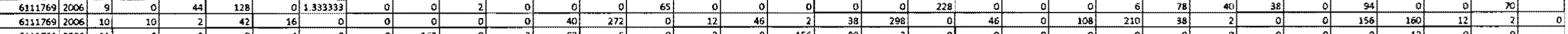

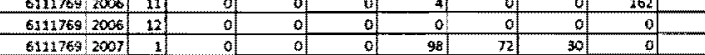

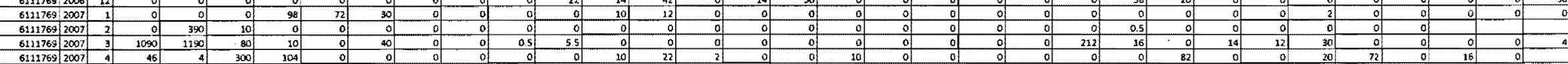

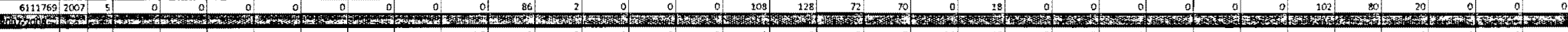

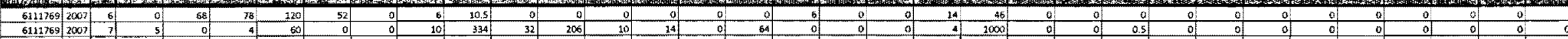

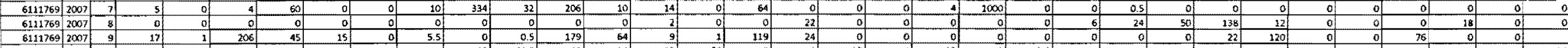

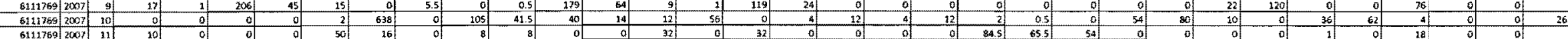

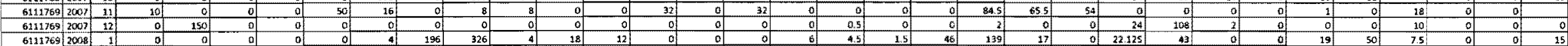

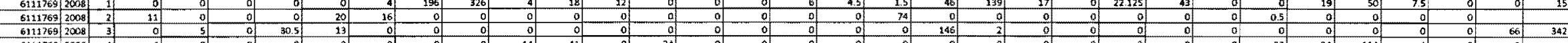

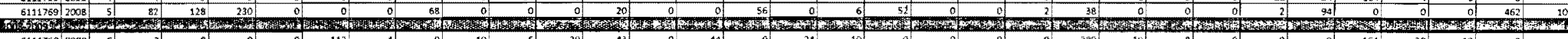

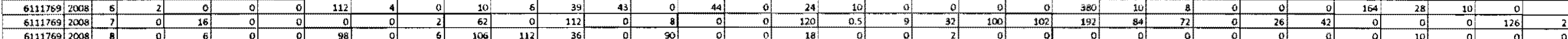
61177692005

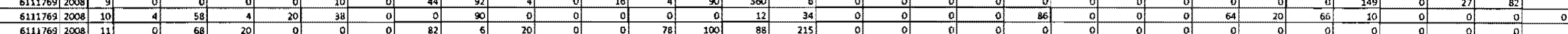

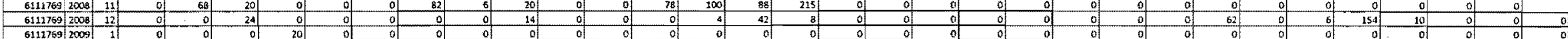

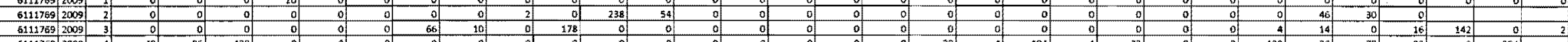

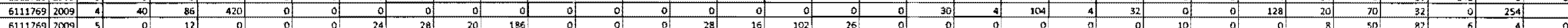

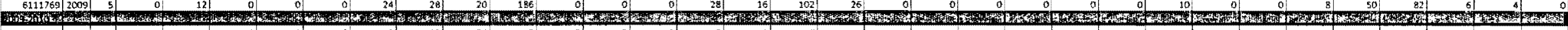

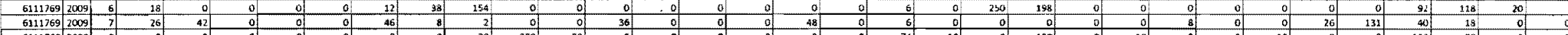

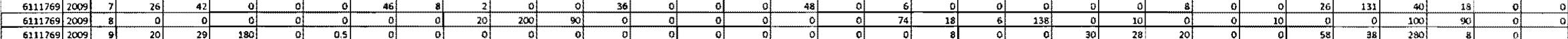

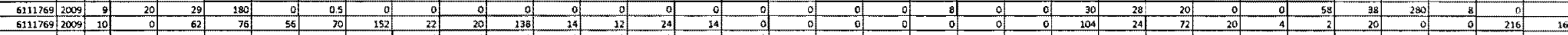

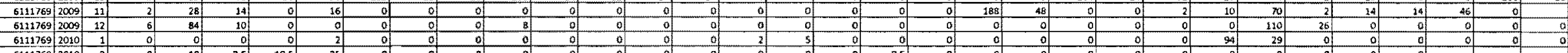

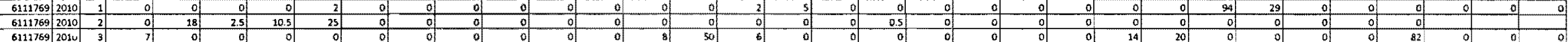

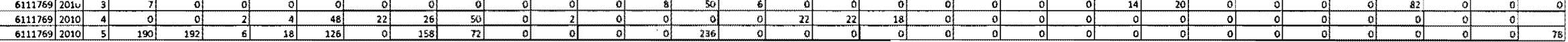




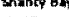

5

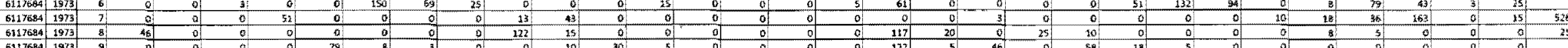

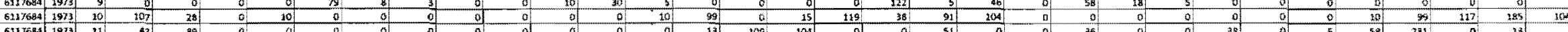

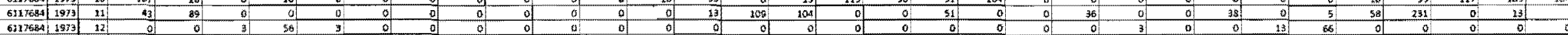

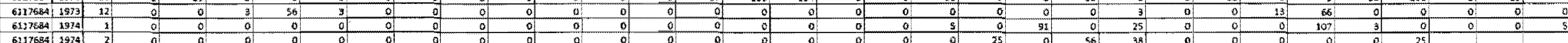

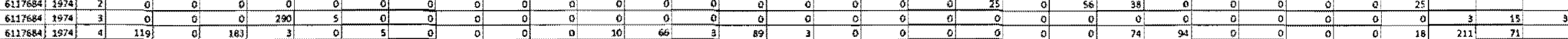

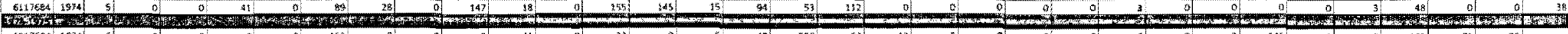

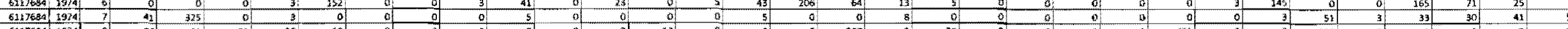

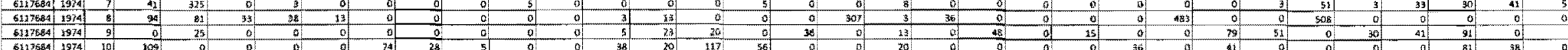

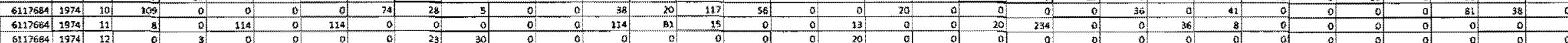

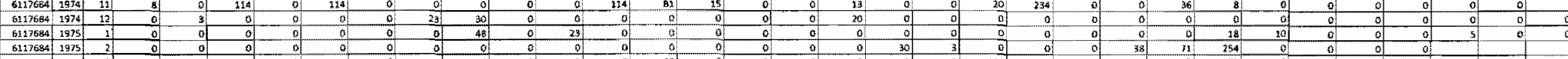

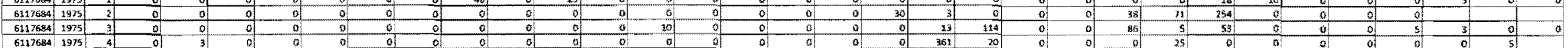

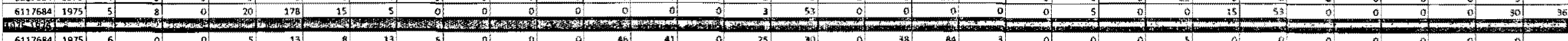

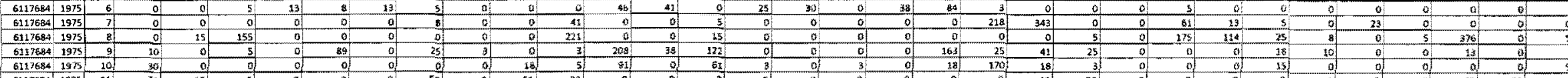

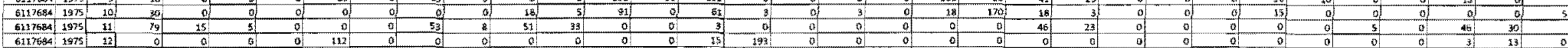

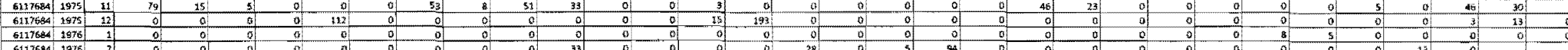

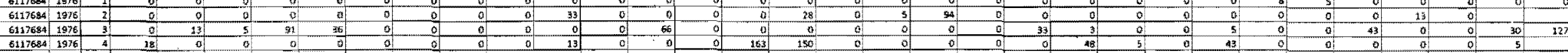

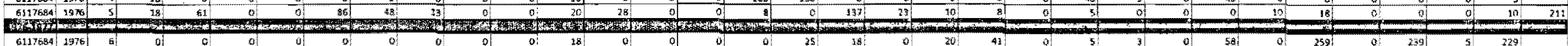

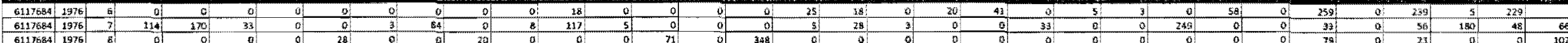

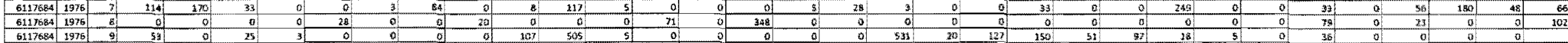

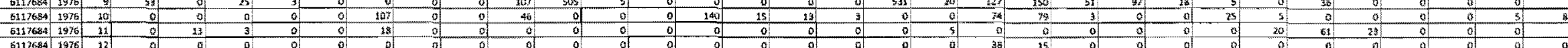

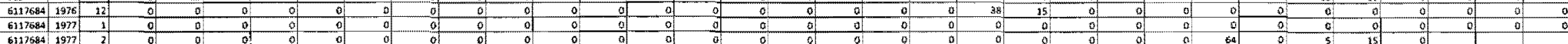

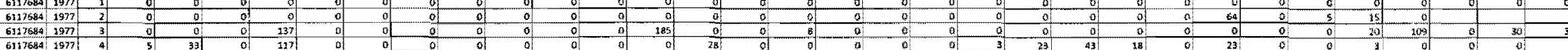

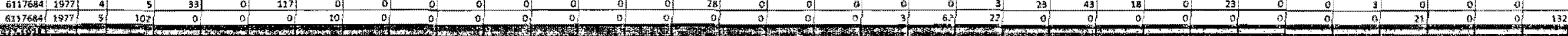

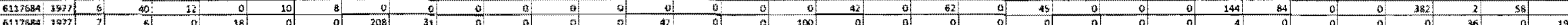

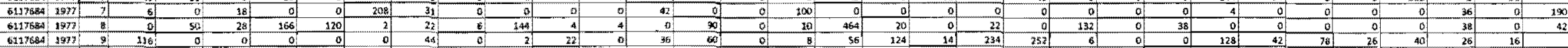

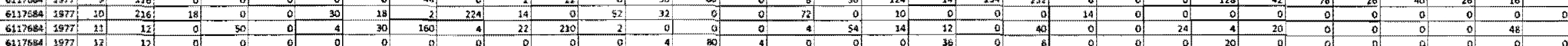

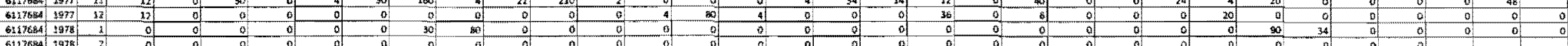

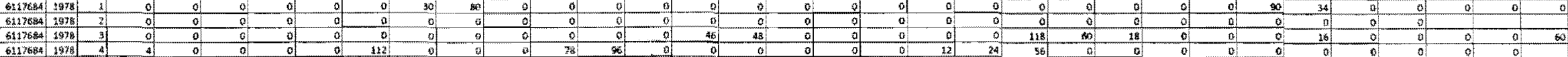

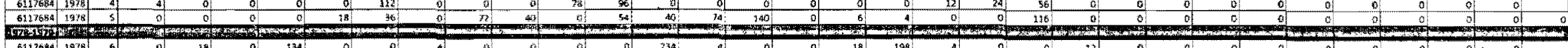

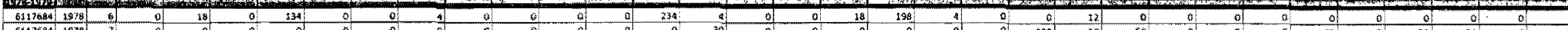

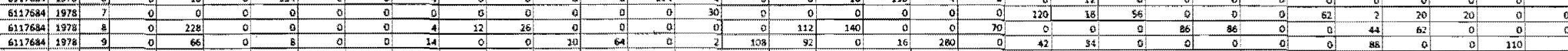

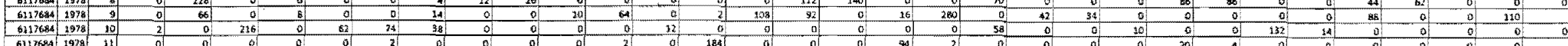

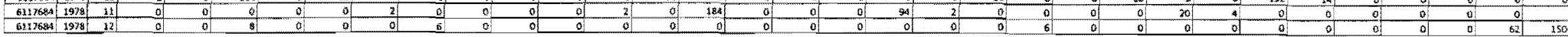


Rainiol Date In 0.1

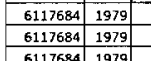

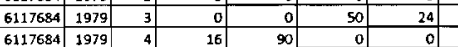

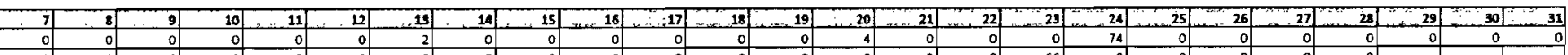

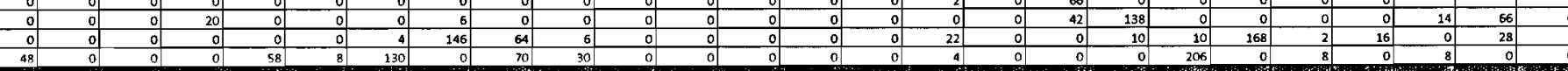

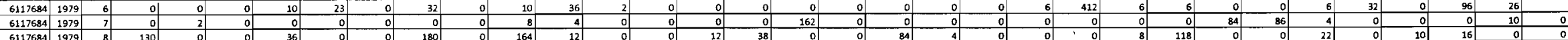

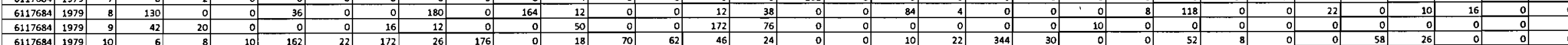

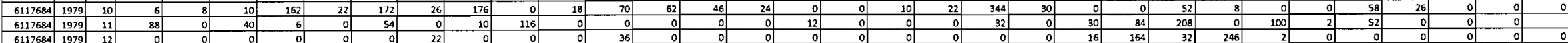

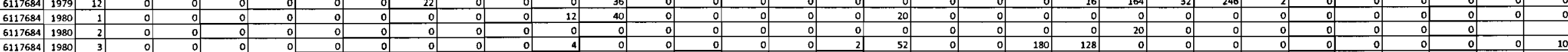

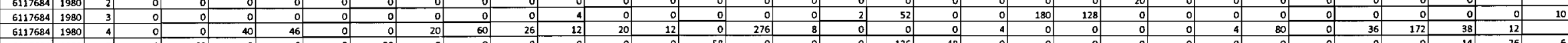

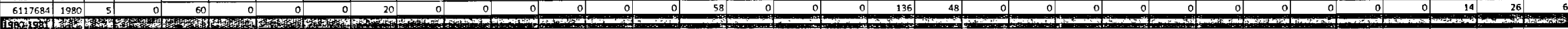

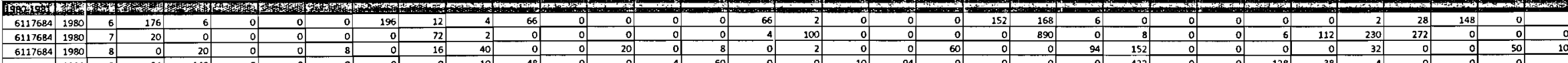

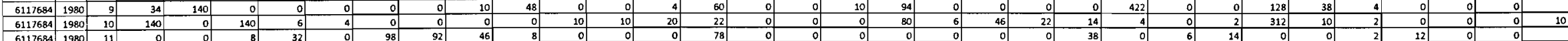

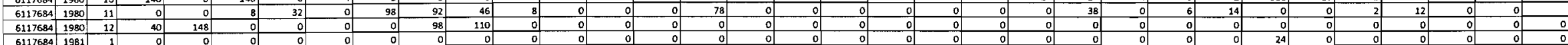

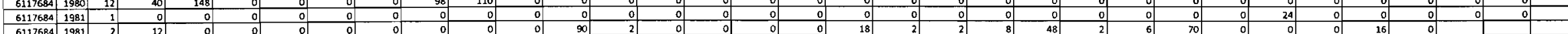

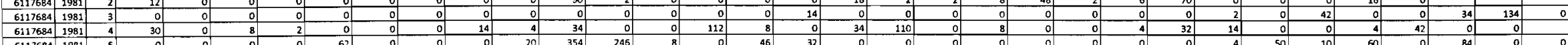

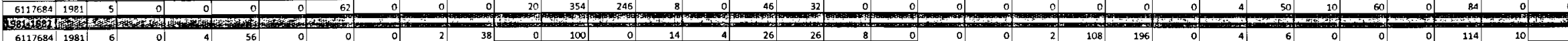

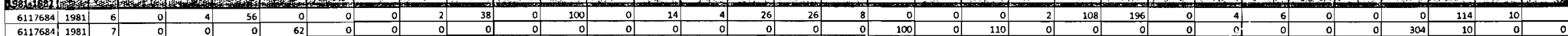

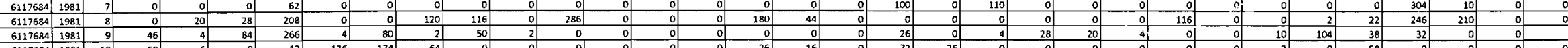

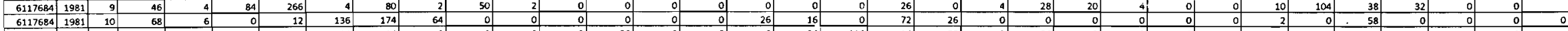

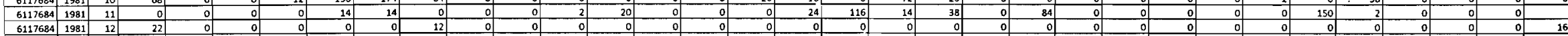

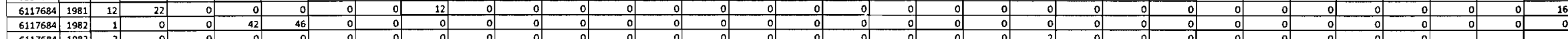

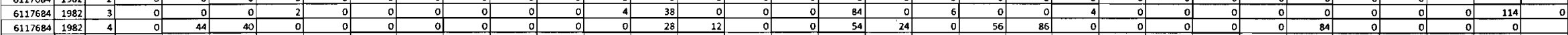




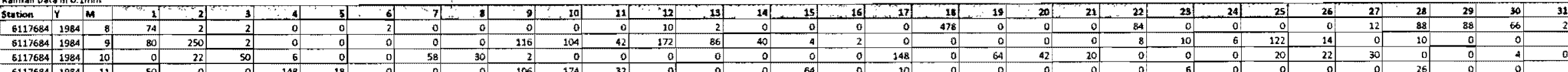

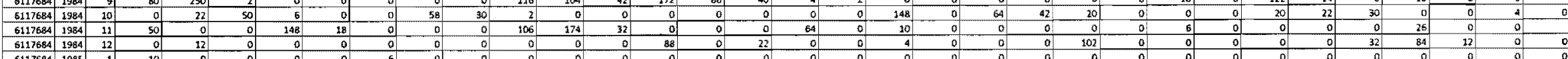

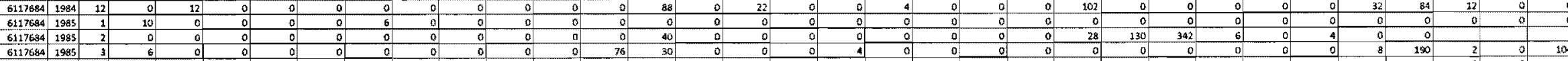

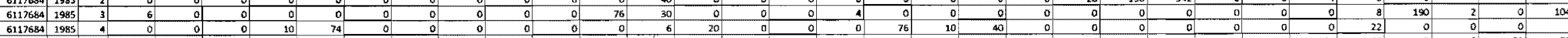

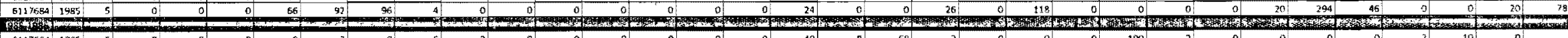

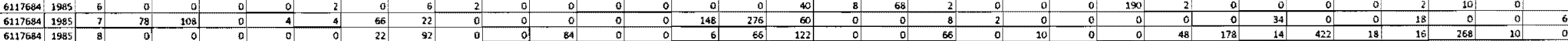

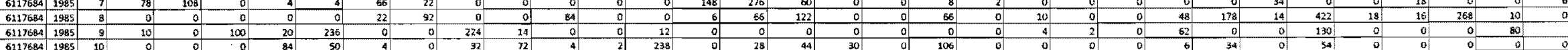

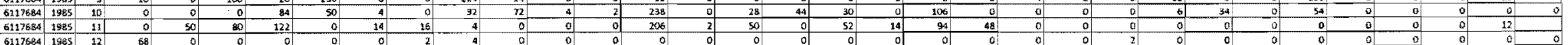

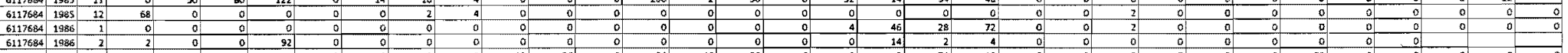

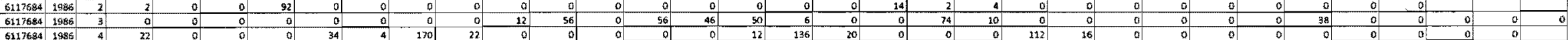

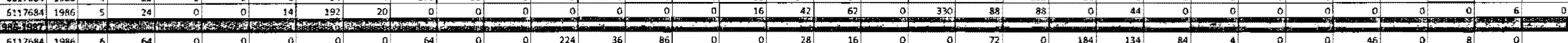

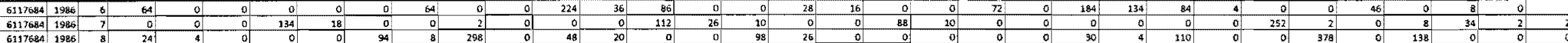

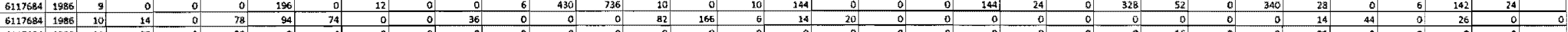

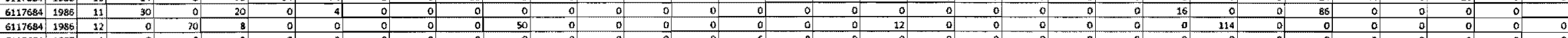

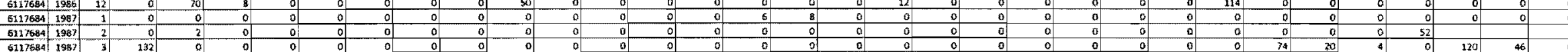

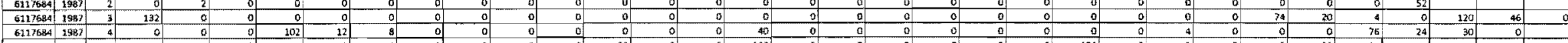

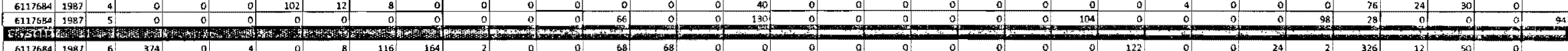

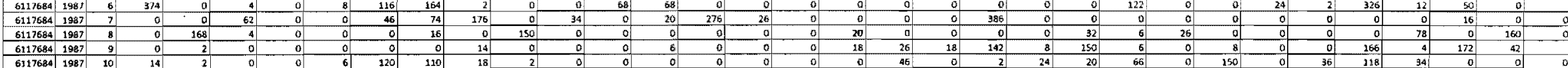

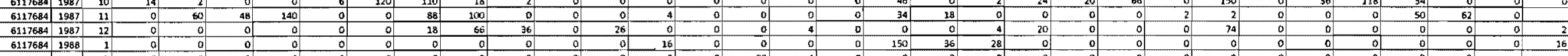

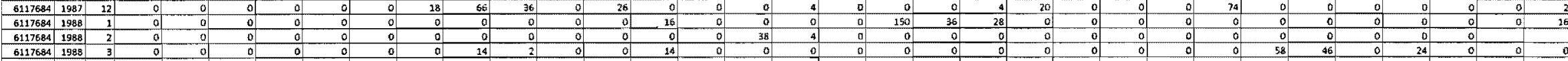

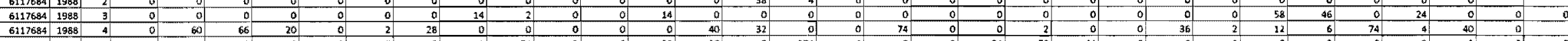

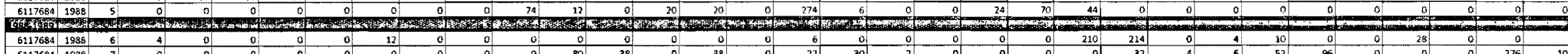

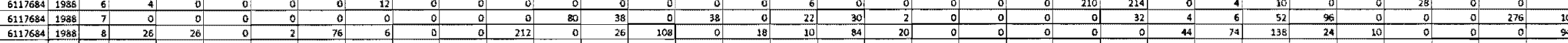

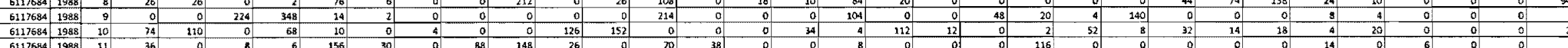

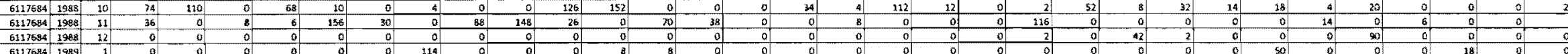

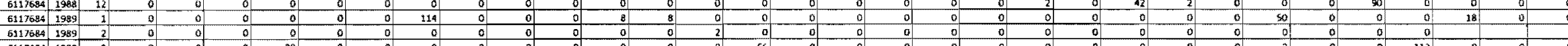

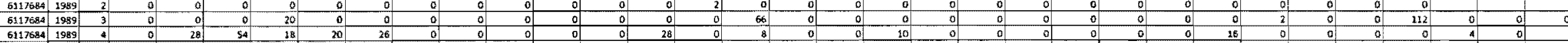

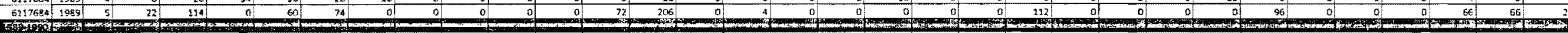

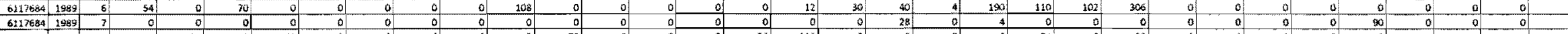

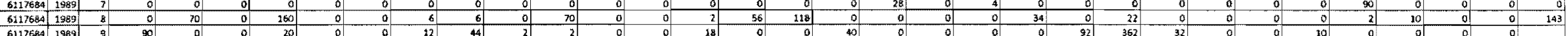

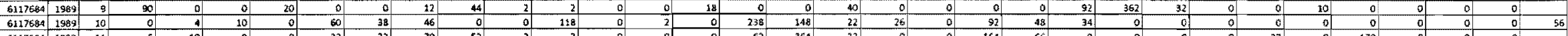

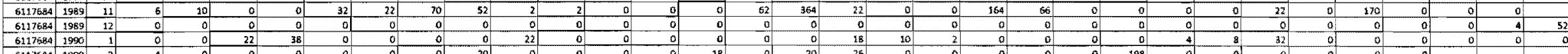

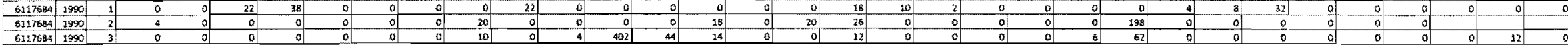


shanly en

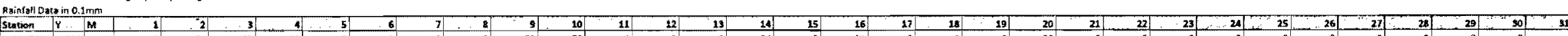

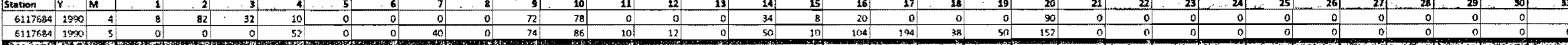

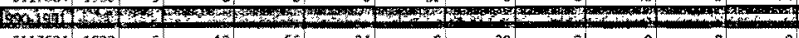

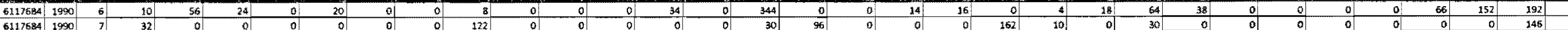

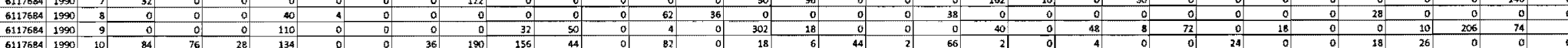

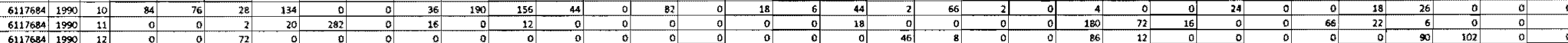

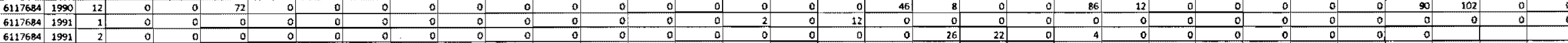

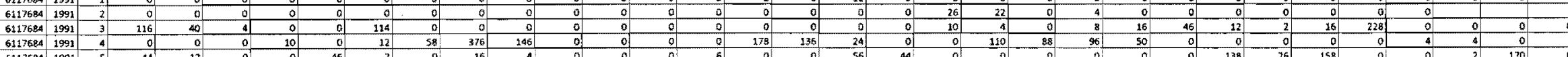

6127684 19:

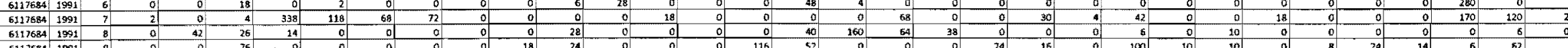

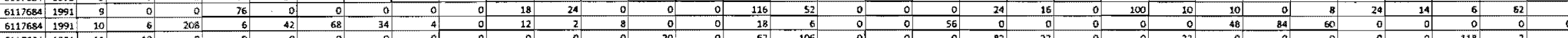

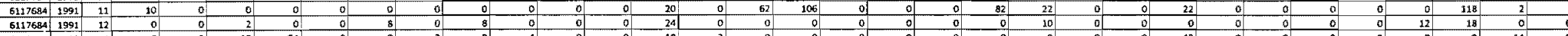

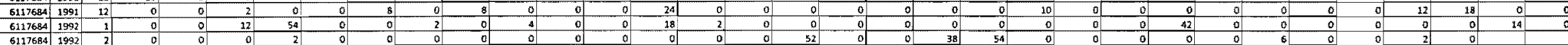

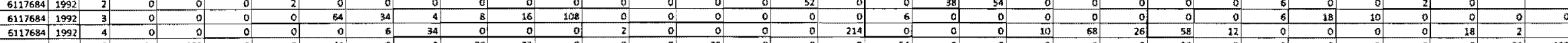

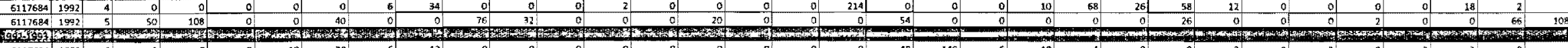

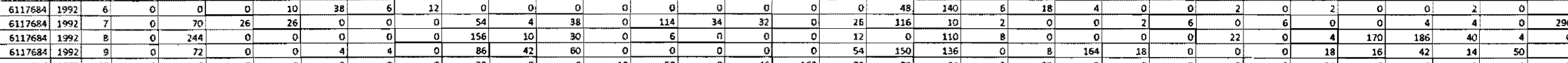

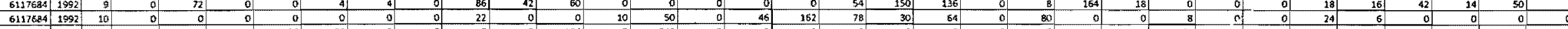

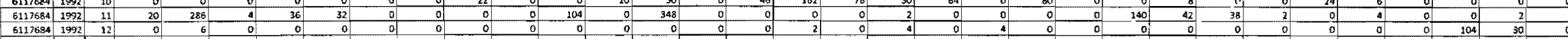

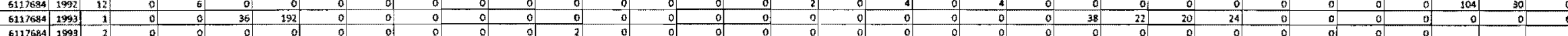

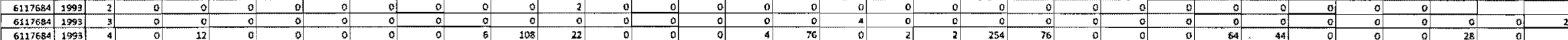

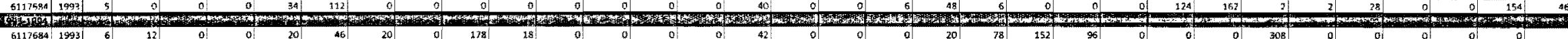

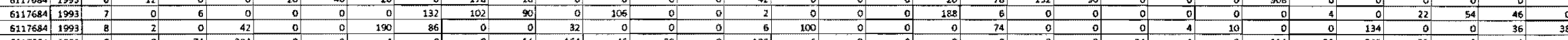

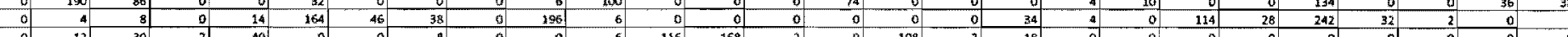

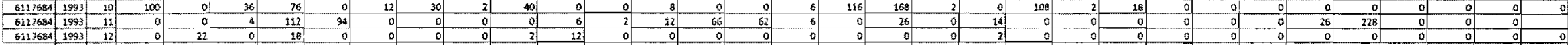

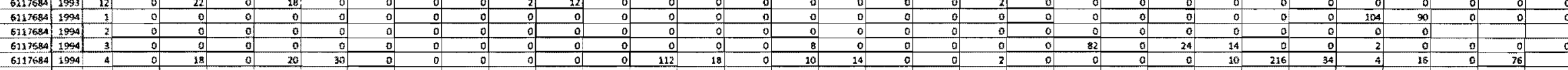

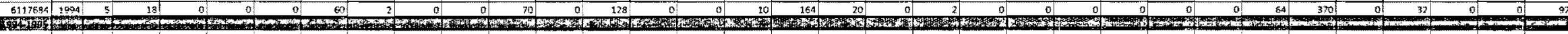

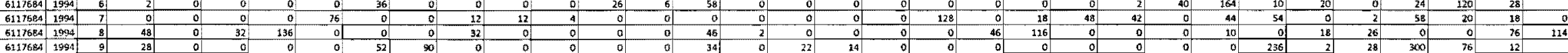

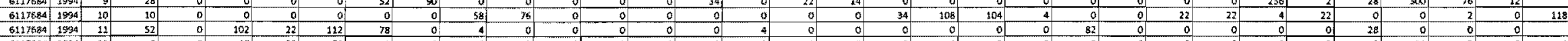

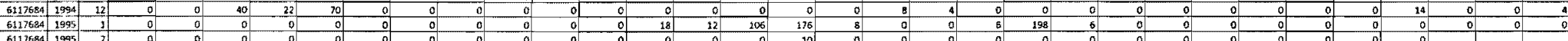

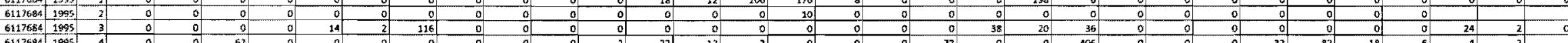

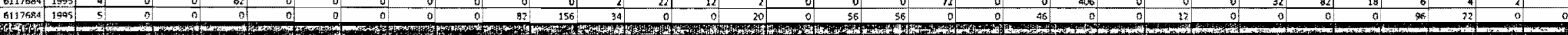

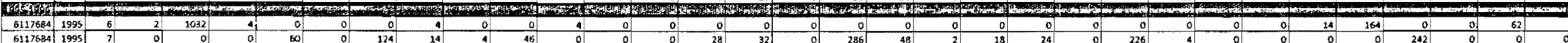

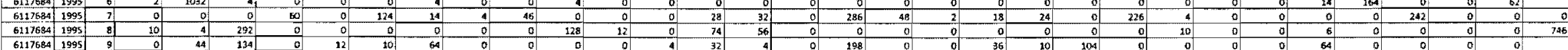

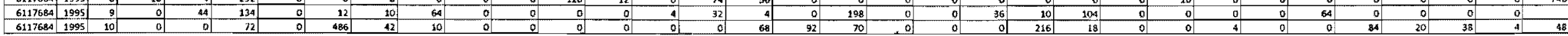




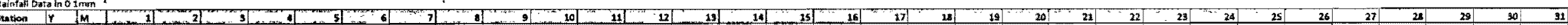

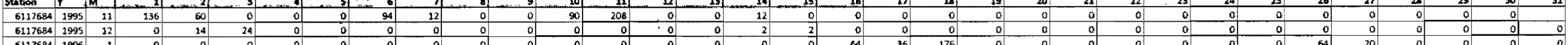

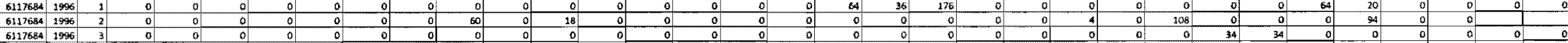

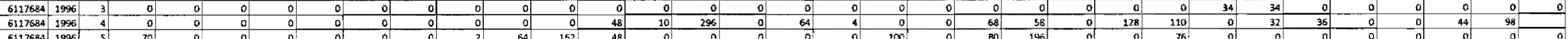

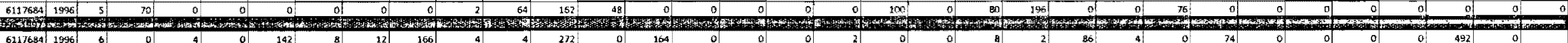

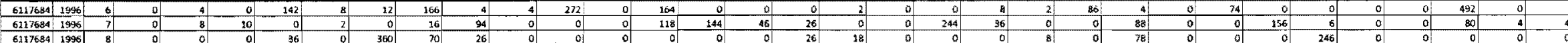

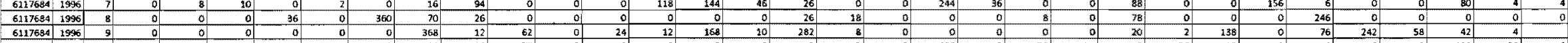

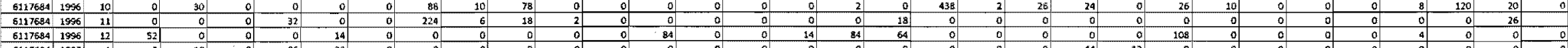

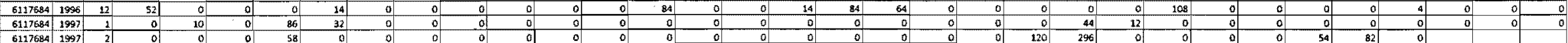

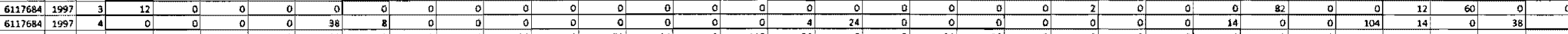

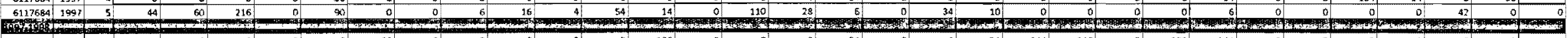

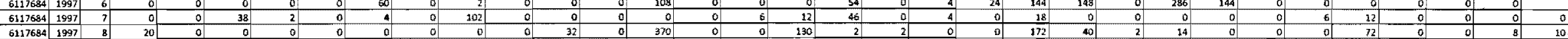

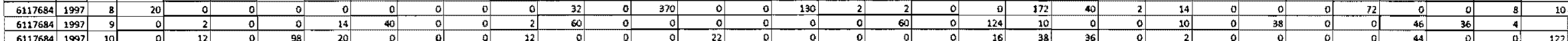

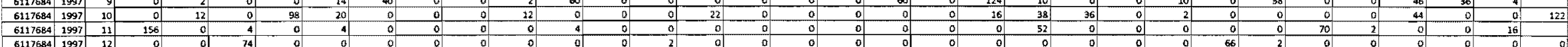

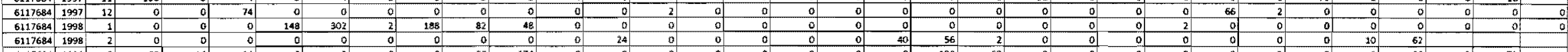

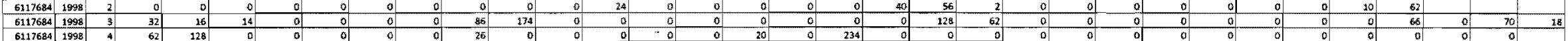

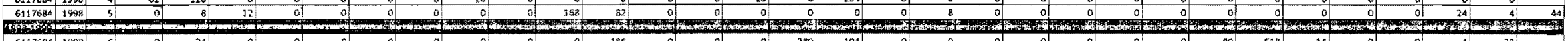

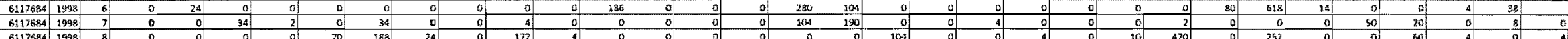

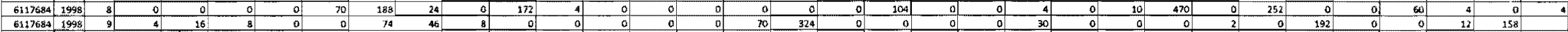

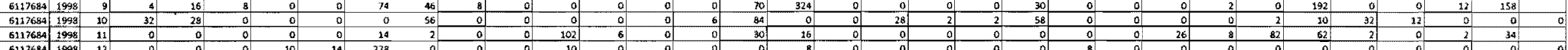

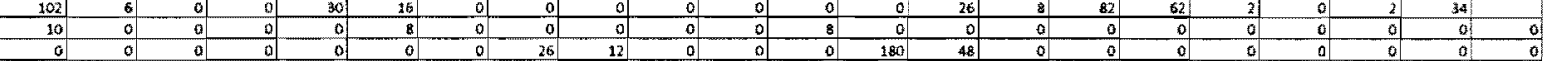

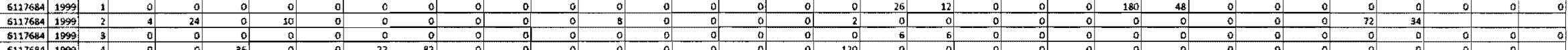

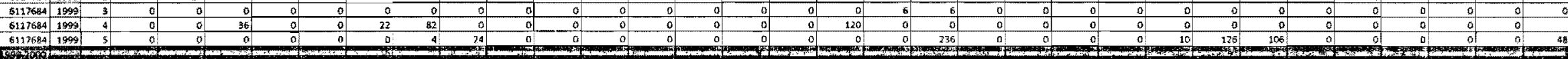

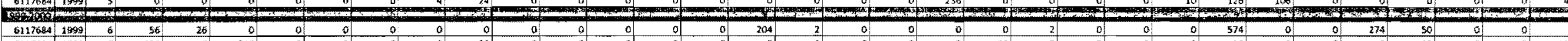

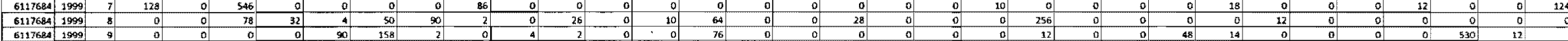

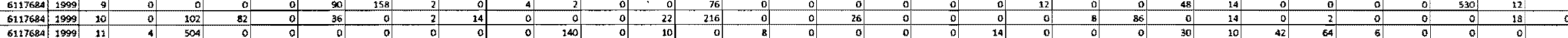

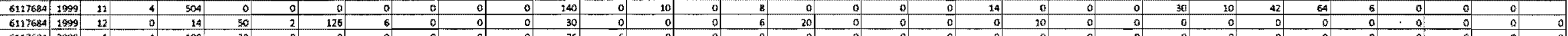

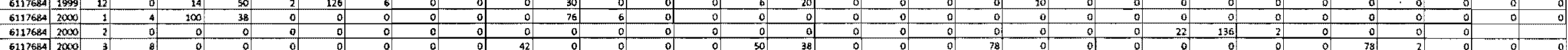

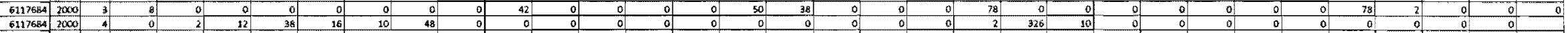

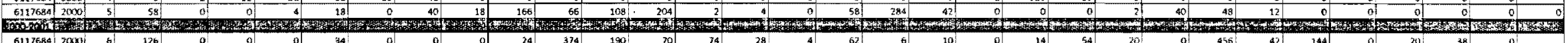

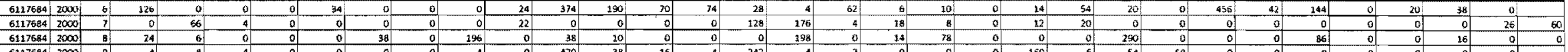

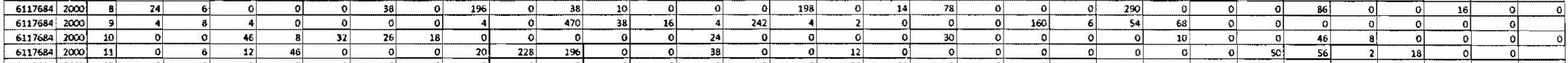

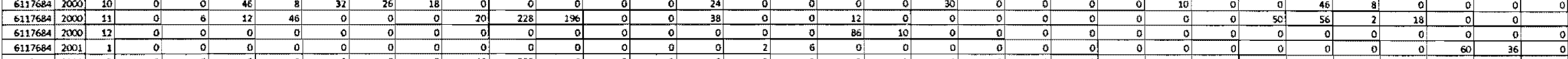

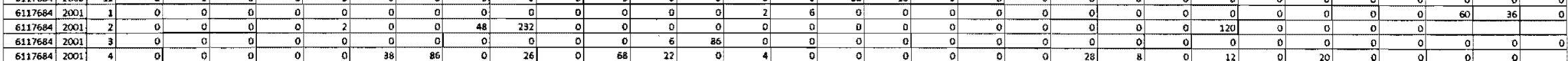

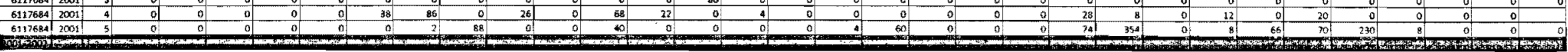


Shanty 6ar

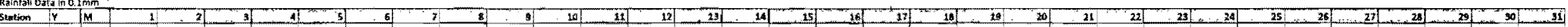

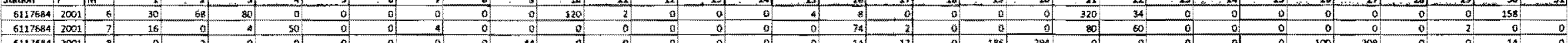

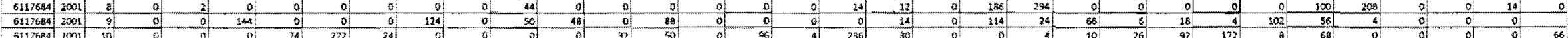

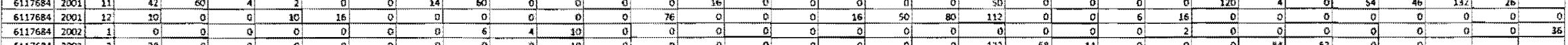

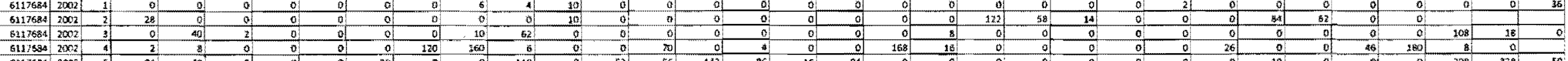

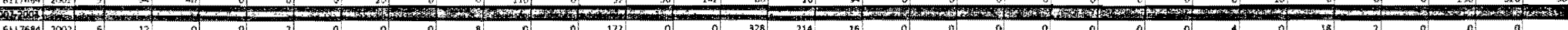

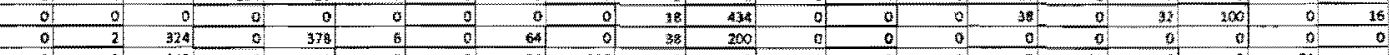

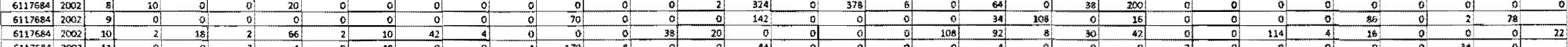

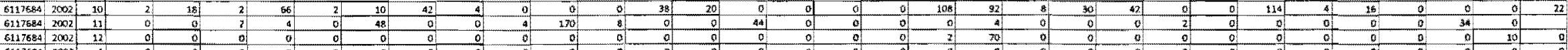

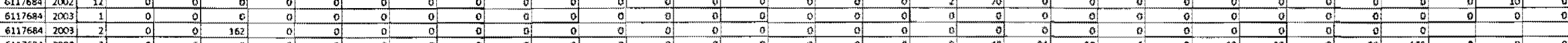

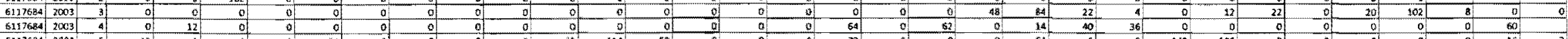

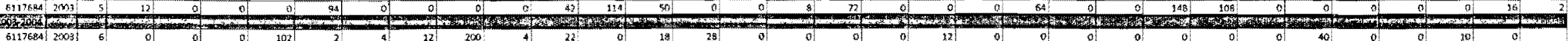

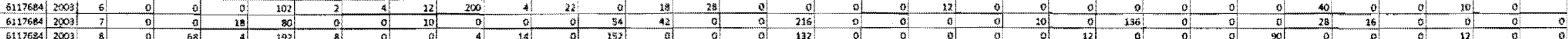

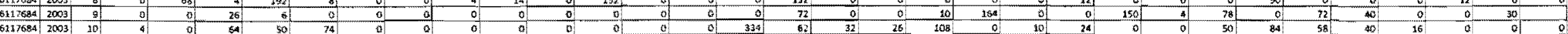

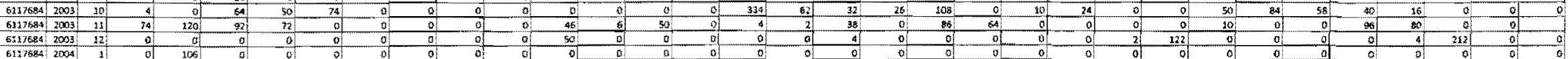

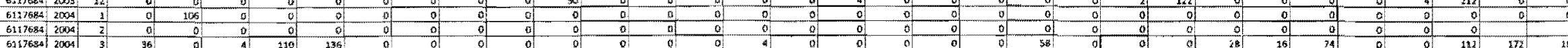

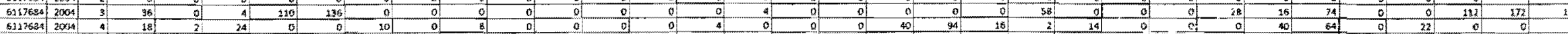

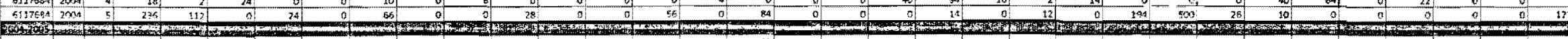

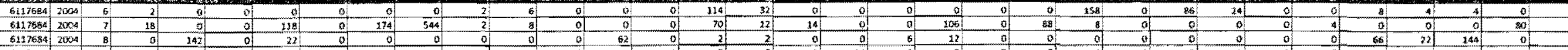

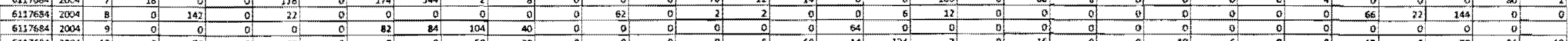

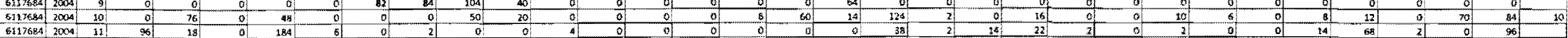

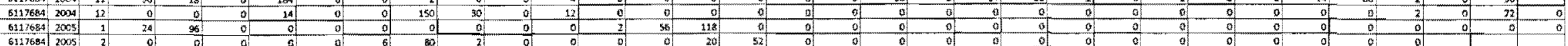

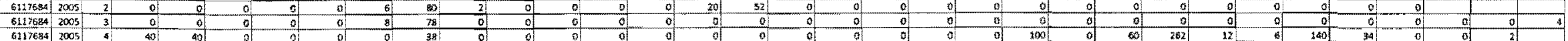

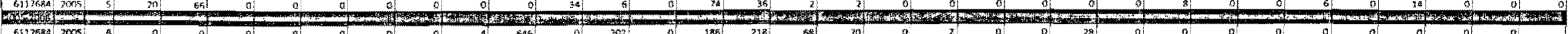

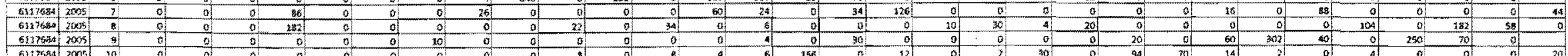

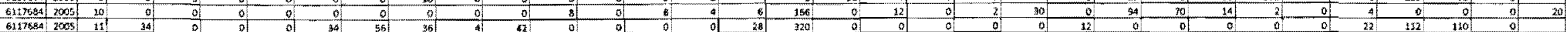

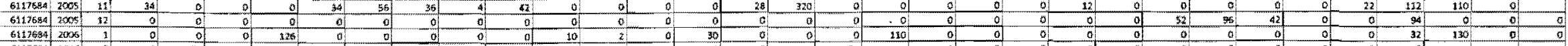

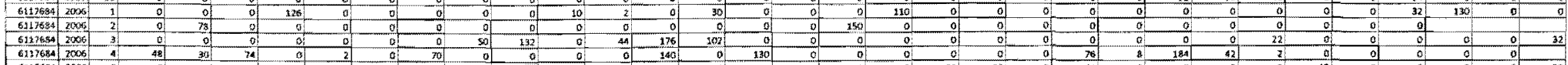

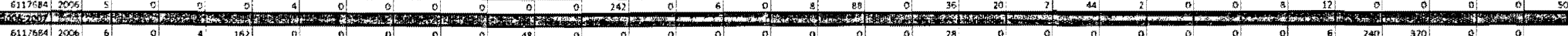

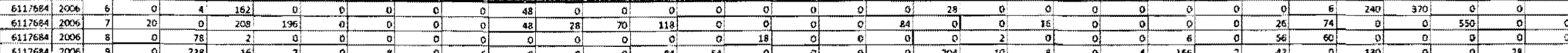

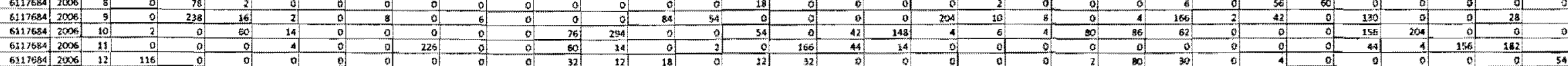

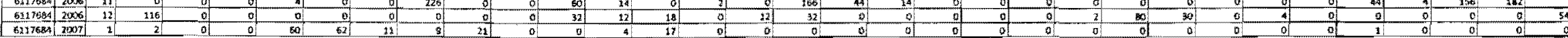




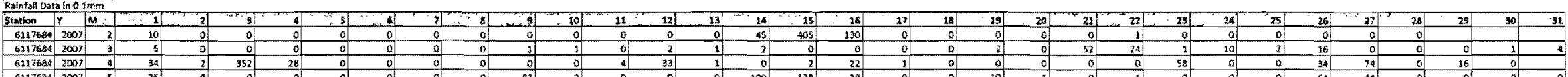

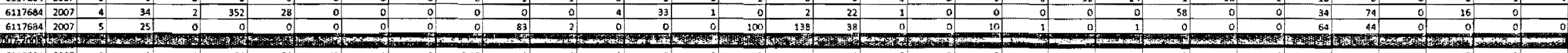

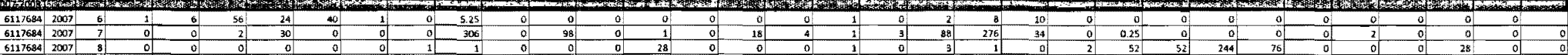

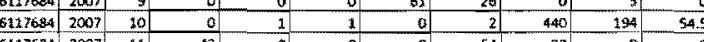

6.17584

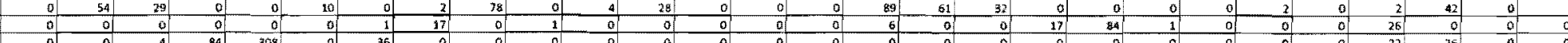

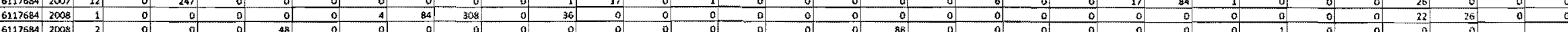

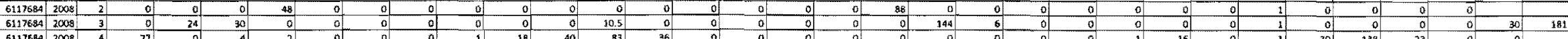

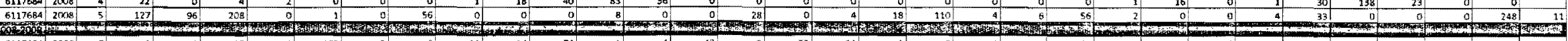

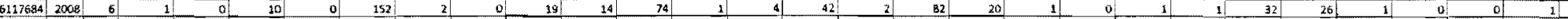

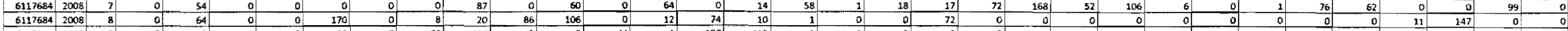

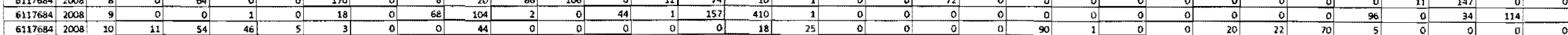

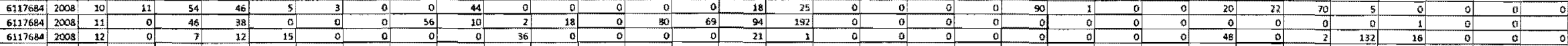

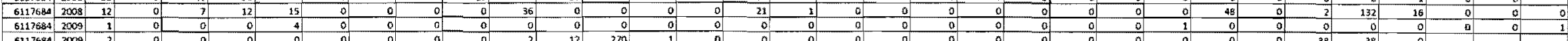

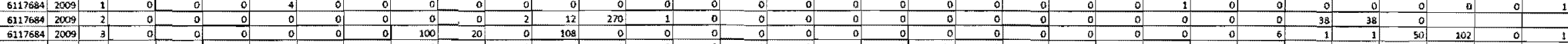

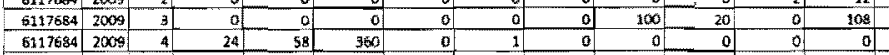

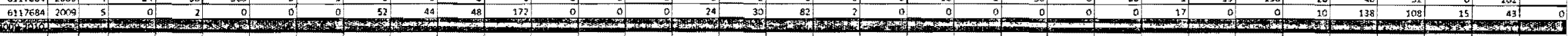

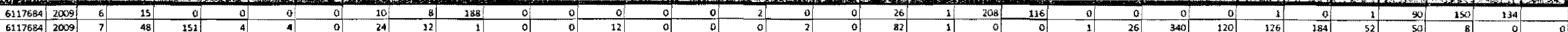

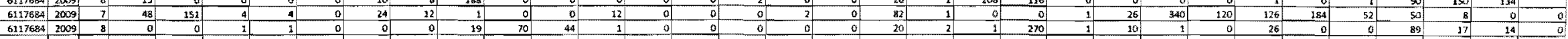

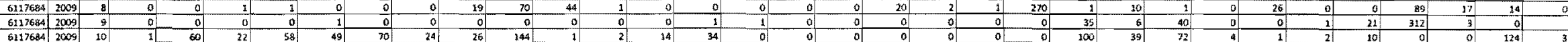

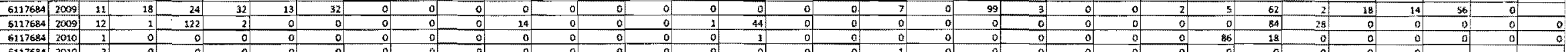

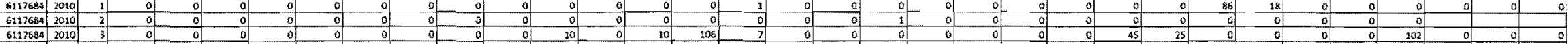

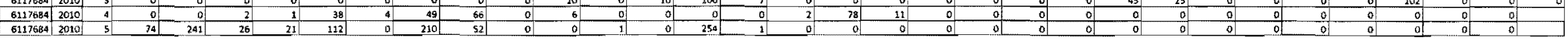




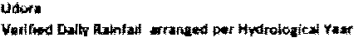




Udors

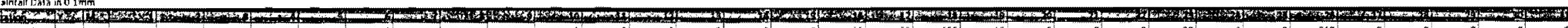

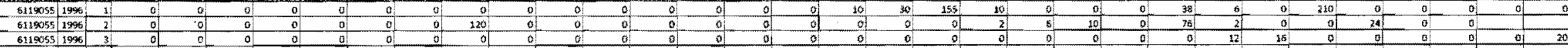

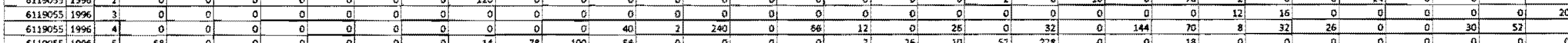

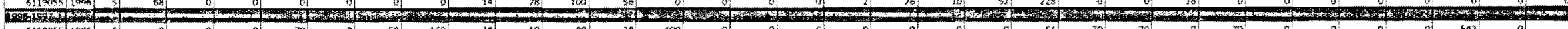

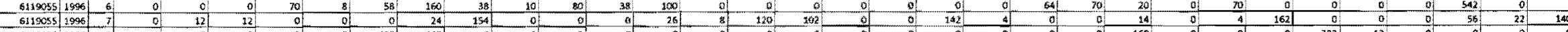

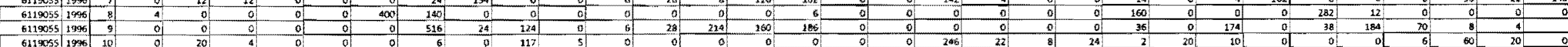

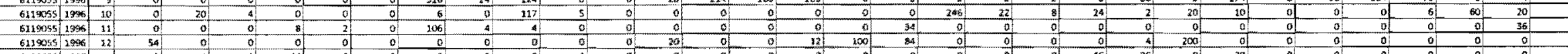

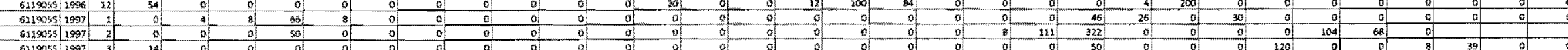

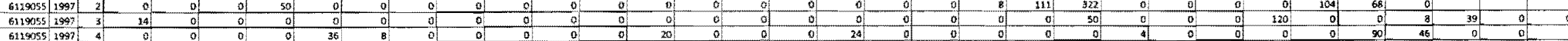

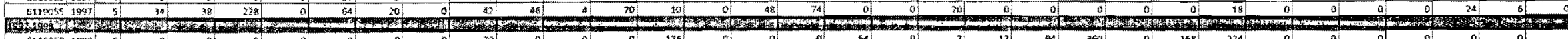

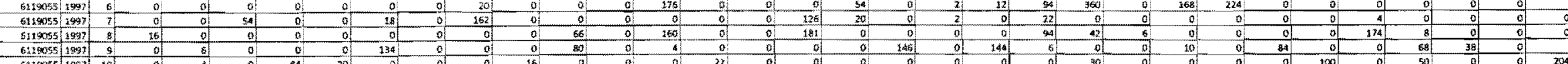

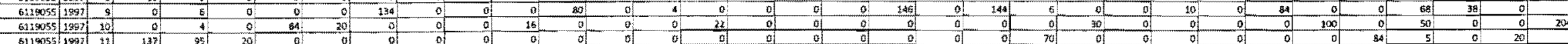

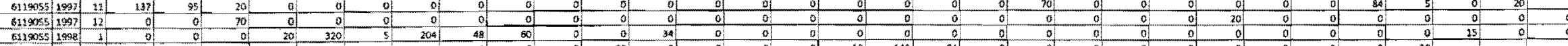

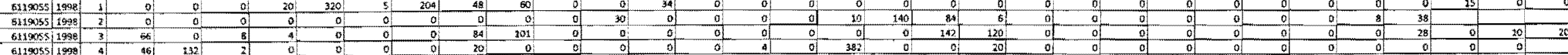

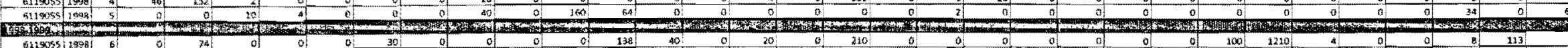

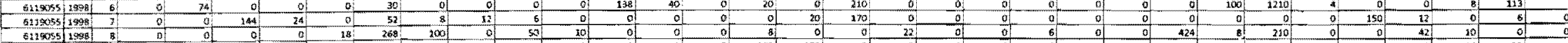

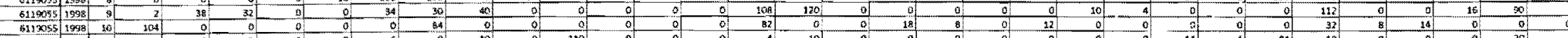

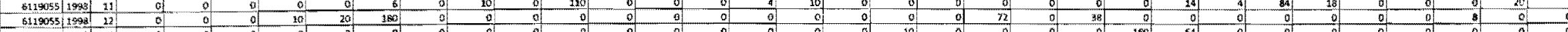

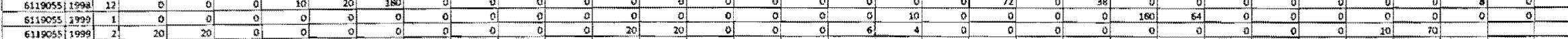

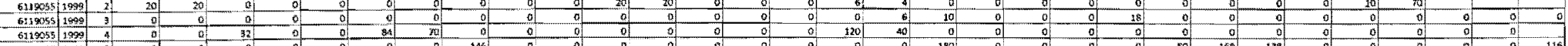

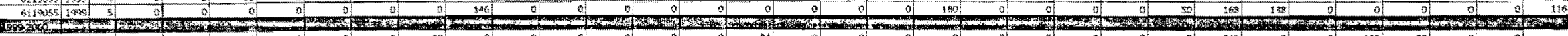

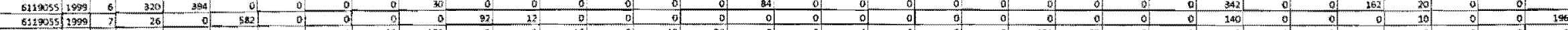

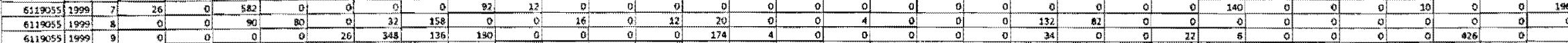

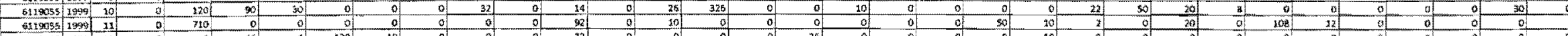

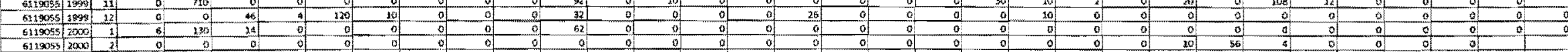

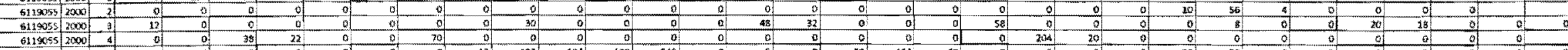

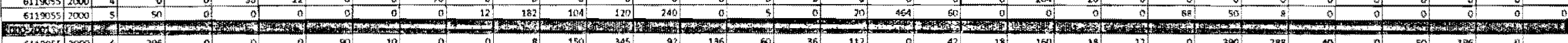

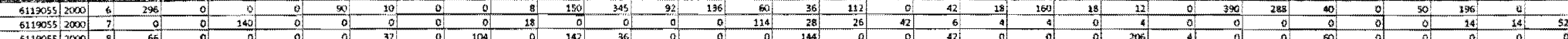

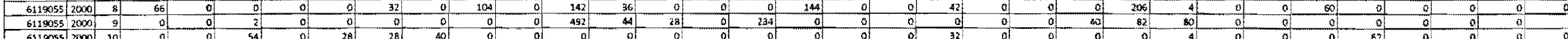

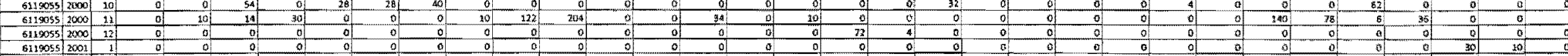

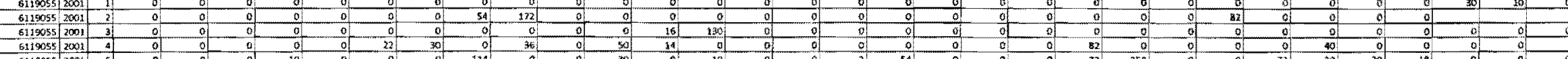
rearbor

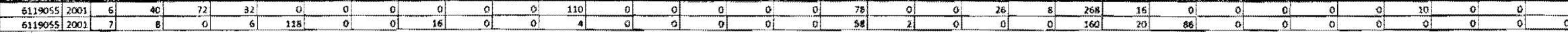




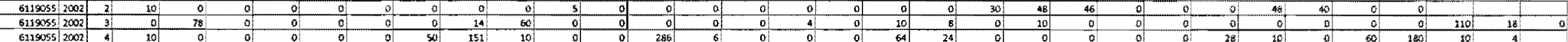

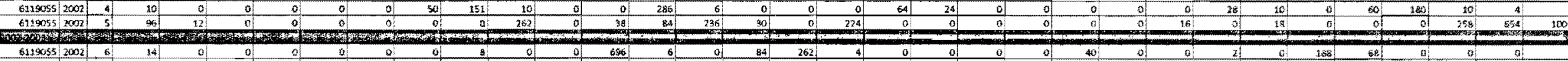

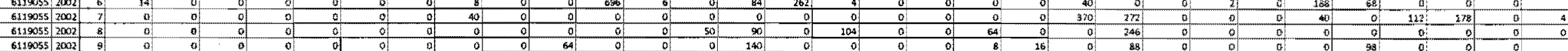

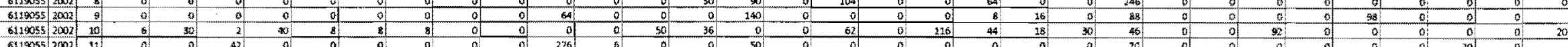

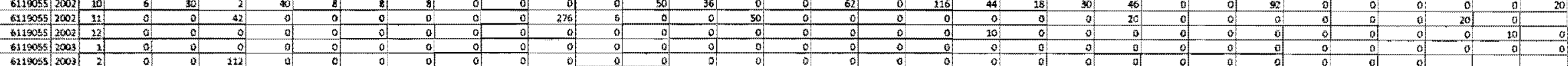

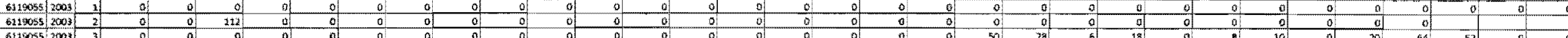

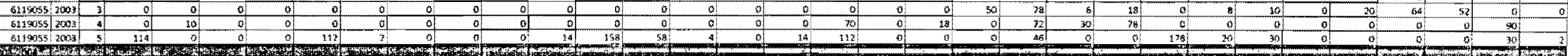

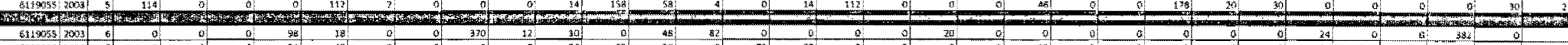

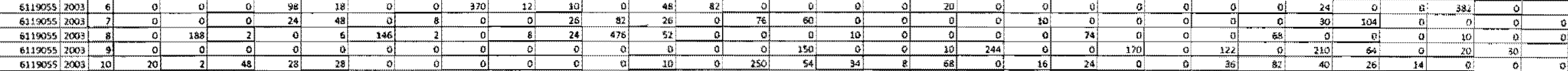

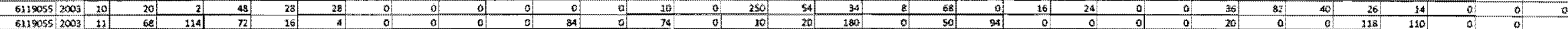

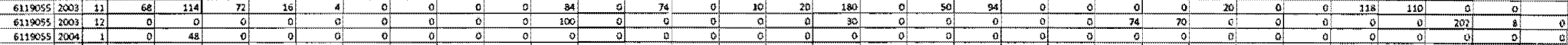

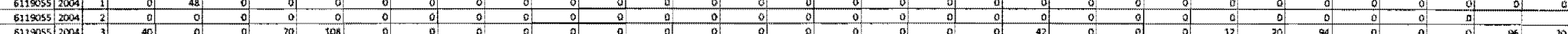

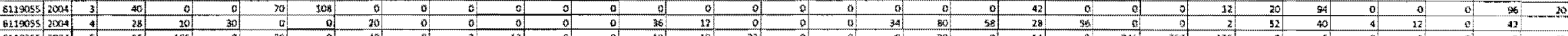

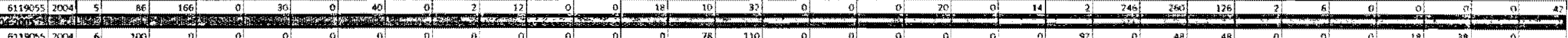

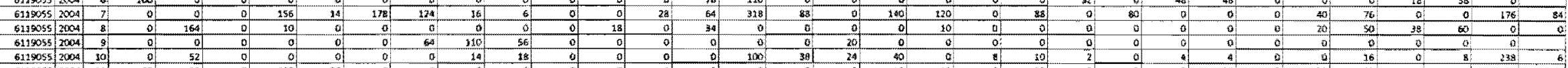

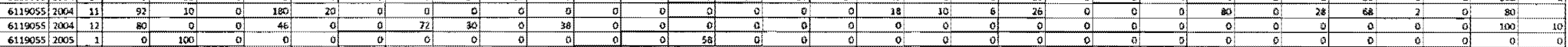

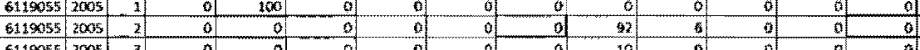

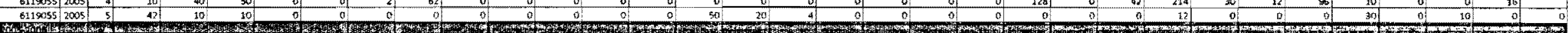

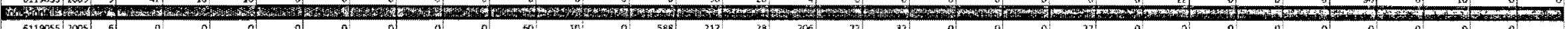

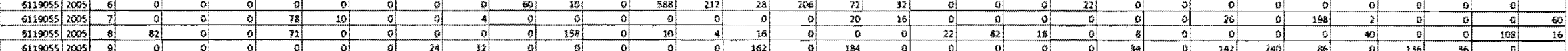

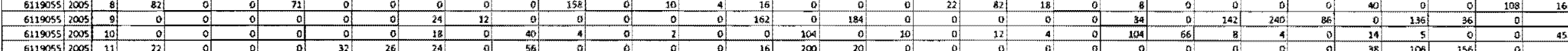

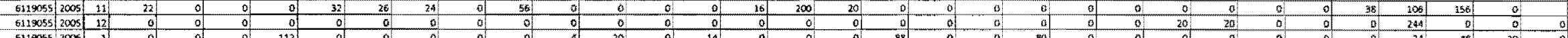

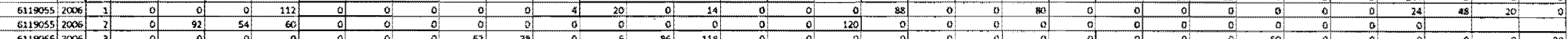

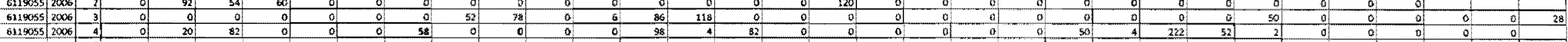

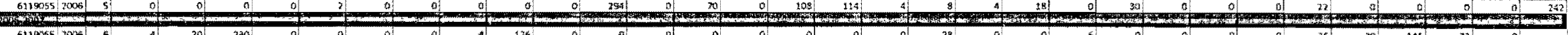

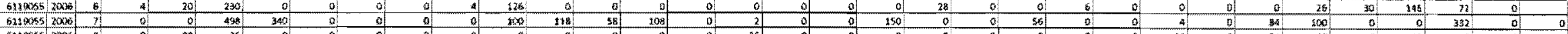

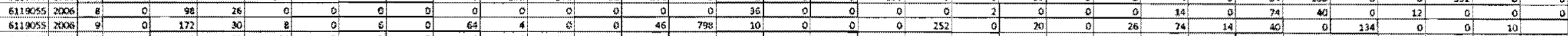

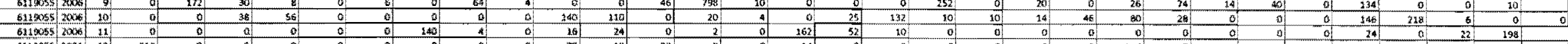

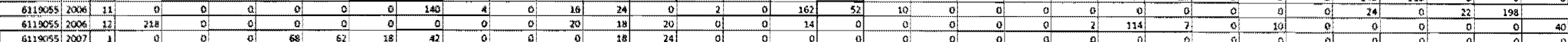

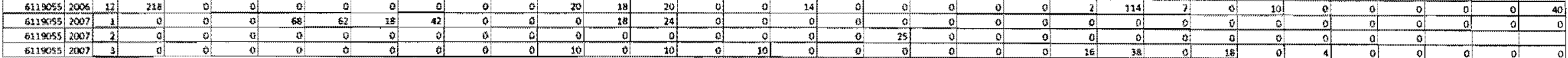

- 
Udore

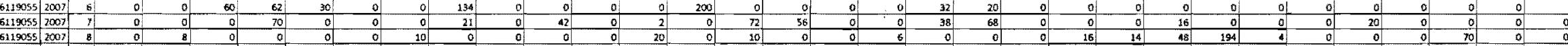

6110055,2807

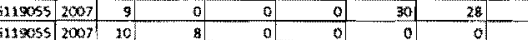

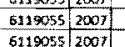

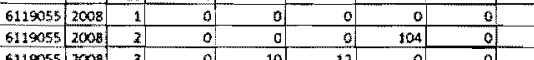

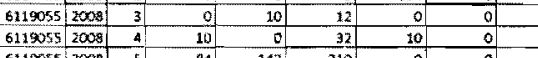

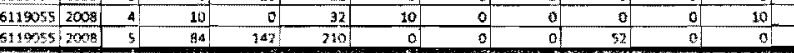

\begin{tabular}{ll|l|l|}
61190055 & 2008 \\
\hline 5119055 & 2008 \\
\hline
\end{tabular}

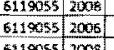

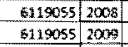

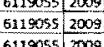

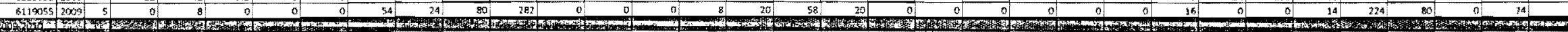

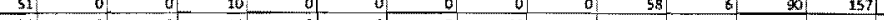

511505528009

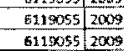

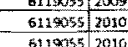

$-6.1190552010$

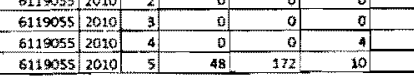

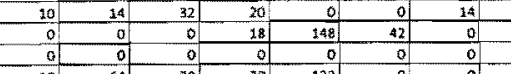

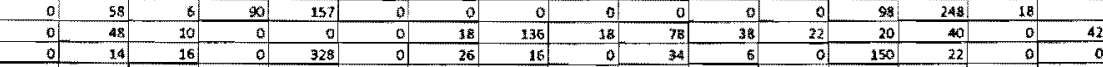
\begin{tabular}{rrrrrrrrrrrrrrr}
48 & 14 & 0 & 0 & 0 & 18 & 135 & 18 & 78 & 38 & 22 & 20 & 20 & 0 & 42 \\
\hline 0 & 8 & 0 & 328 & 0 & 36 & 15 & 0 & 34 & 6 & 0 & 150 & 22 & 0 & 0 \\
\hline 0 & 0 & 0 & 0 & 32 & 0 & 74 & 0 & 0 & 32 & 12 & 328 & 2 & 0 & \\
\hline
\end{tabular}

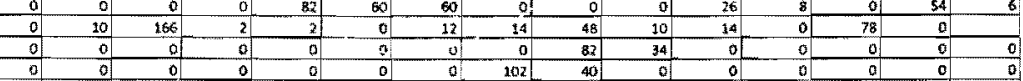
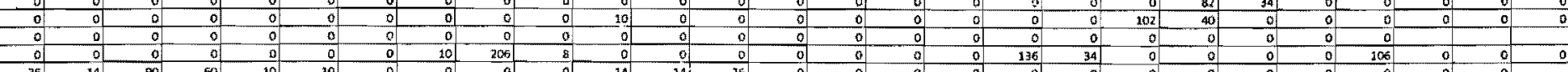


\section{Appendix C}

\section{Verified Daily Rainfall Arranged Per Month}


Barrie WPCC

Average Daily Rainfall per month

Total Rainfall (mm)

\begin{tabular}{|c|c|c|c|c|c|c|c|c|c|c|c|c|}
\hline \multirow[b]{2}{*}{ Year/Month } & \multicolumn{10}{|c|}{ lotal Rainfall $(\mathrm{mm})$} & \multirow[b]{2}{*}{11} & \multirow[b]{2}{*}{12} \\
\hline & 1 & 2 & 3 & 4 & 5 & 6 & 7 & 8 & 9 & 10 & & \\
\hline \multicolumn{13}{|l|}{1972} \\
\hline \multicolumn{13}{|l|}{1973} \\
\hline \multicolumn{13}{|l|}{1974} \\
\hline \multicolumn{13}{|l|}{1975} \\
\hline \multicolumn{13}{|l|}{1976} \\
\hline \multicolumn{13}{|l|}{1977} \\
\hline 1978 & & & & & & 66.70 & 29.60 & 113.50 & 87.40 & 73.30 & 32.30 & 11.40 \\
\hline 1979 & 4.00 & 2.30 & 38.20 & 60.40 & 75.20 & 72.10 & 25.40 & 81.50 & 41.40 & 145.00 & 90.10 & 49.30 \\
\hline 1980 & 6.00 & 0.00 & 38.30 & 86.20 & 29.70 & 92.40 & 166.30 & 39.40 & 77.10 & 87.60 & 32.60 & 34.60 \\
\hline 1981 & 0.00 & 20.10 & 19.20 & 49.90 & 94.50 & 71.60 & 57.70 & 126.30 & 76.70 & 73.90 & 68.10 & 5.00 \\
\hline 1982 & 11.80 & 0.00 & 30.00 & 42.30 & 46.80 & 119.80 & 68.70 & 98.30 & 68.10 & 41.60 & 97.90 & 82.80 \\
\hline 1983 & 17.60 & 4.00 & 31.40 & 75.80 & 97.00 & 26.00 & 61.20 & 59.60 & 76.90 & 80.80 & 70.10 & 8.80 \\
\hline 1984 & 0.00 & 12.20 & 28.20 & 51.90 & 95.30 & 44.80 & 40.80 & 83.60 & 117.70 & 43.10 & 61.40 & 39.60 \\
\hline 1985 & 3.00 & 43.20 & $35.4 \overline{0}$ & 42.50 & 86.90 & 44.30 & 92.80 & 159.10 & 62.90 & 74.80 & 81.20 & 5.80 \\
\hline 1986 & 11.70 & 0.50 & 30.50 & 59.90 & 92.80 & 97.00 & 76.10 & 124.90 & 303.00 & 76.80 & 21.00 & 13.00 \\
\hline 1987 & 0.00 & 6.00 & 45.40 & 40.40 & 59.20 & 126.60 & 145.00 & 80.20 & 67.00 & 86.60 & 64.00 & 15.40 \\
\hline 1988 & 29.00 & 3.00 & 16.80 & 60.00 & 73.00 & 27.40 & 87.30 & 91.80 & 126.60 & 104.80 & 67.80 & 16.00 \\
\hline 1989 & 24.00 & 0.00 & 16.00 & 28.60 & 115.20 & 89.20 & 2.80 & 96.40 & 75.10 & 90.30 & 77.20 & 0.00 \\
\hline 1990 & 16.00 & 19.00 & 54.20 & 49.80 & 87.80 & 81.20 & 66.40 & 35.00 & 105.20 & 108.40 & 81.20 & 33.20 \\
\hline 1991 & 0.00 & 4.00 & 58.40 & 124.80 & 70.40 & 35.00 & 114.00 & 36.00 & 58.20 & 65.60 & 43.00 & 7.00 \\
\hline 1992 & 9.60 & 8.00 & 25.00 & 50.10 & 55.30 & 32.60 & 86.30 & 106.50 & 95.70 & 44.90 & 115.60 & 13.80 \\
\hline 1993 & 22.40 & 0.00 & 0.00 & 67.20 & 80.20 & 93.30 & 71.20 & 76.60 & 122.80 & 61.30 & 53.20 & 16.70 \\
\hline 1994 & 18.40 & 0.00 & 15.80 & 55.80 & 105.00 & 59.00 & 48.60 & 74.00 & 88.80 & 57.80 & 57.00 & 20.00 \\
\hline 1995 & 55.80 & 1.60 & 21.00 & 74.70 & 57,20 & 132.00 & 113.30 & 158.00 & 63.70 & 130.90 & 76.00 & 3.00 \\
\hline 1996 & 24.20 & 29.20 & 3.40 & 111.20 & 76.80 & 102.20 & 117.60 & 68.20 & 187.40 & 88.40 & 27.00 & 44.50 \\
\hline 1997 & 12.50 & 54.80 & 31.60 & 31.80 & 83.00 & 93.10 & 28.40 & 91.60 & 56.00 & 48.20 & 39.10 & 7.00 \\
\hline 1998 & 52.80 & 31.40 & 70.00 & 50.40 & 38.50 & 89.10 & 28.00 & 162.20 & 91.70 & 32.80 & 55.70 & 38.00 \\
\hline 1999 & 10.00 & 13.00 & 1.00 & 23.80 & 60.40 & 146.90 & 105.70 & 68.80 & 97.90 & 75.80 & 73.40 & 23.70 \\
\hline 2000 & 20.80 & 18.00 & 47.80 & 48.00 & 133.00 & 219.50 & 53.80 & 97.20 & 94.90 & 27.50 & 66.90 & 10.60 \\
\hline 2001 & 5.20 & 34.60 & 10.00 & 35.40 & 100.10 & 85.60 & 41.70 & 61.40 & 85.60 & 154.60 & 64.70 & 51.50 \\
\hline 2002 & 5.40 & 35.90 & 29.20 & 82.20 & 127.80 & 73.00 & 64.20 & 83.40 & 53.20 & 66.40 & 29.00 & 8.50 \\
\hline 2003 & 0.00 & 0.00 & 29.50 & 35.50 & 81.30 & 61.30 & 90.70 & 170.60 & 76.60 & 103.60 & 112.40 & 47.80 \\
\hline 2004 & 8.00 & 0.00 & 72.50 & 37.90 & 147.40 & 43.30 & 151.80 & 39.80 & 39.40 & 56.20 & 60.50 & 20.00 \\
\hline 2005 & 30.00 & 8.40 & 8.80 & 77.50 & 34.30 & 124.40 & 60.20 & 49.90 & 81.80 & 38.20 & 87.10 & 27,87 \\
\hline 2006 & 45.00 & 15.00 & 35.20 & 63.40 & 55.20 & & & & & & & \\
\hline \multicolumn{13}{|l|}{2007} \\
\hline \multicolumn{13}{|l|}{2008} \\
\hline 2009 & & & & & & & $\therefore$ & & & & & \\
\hline Average & 15.83 & 13.01 & 30.10 & 57.76 & 80.69 & 83.91 & 74.84 & 90,49 & 92.10 & 76.40 & 64.48 & 23.39 \\
\hline
\end{tabular}


Coldwater Warminster

Verified Daily Rainfall arranged per month

\begin{tabular}{|c|c|c|c|c|c|c|c|c|c|c|c|c|}
\hline \multirow[b]{2}{*}{ Year/Month } & & \multicolumn{4}{|c|}{ Total Rainfall $(\mathrm{mm})$} & \multirow[b]{2}{*}{9} & \multirow[b]{2}{*}{10} & \multirow[b]{2}{*}{11} & \multirow[b]{2}{*}{12} \\
\hline & 1 & 2 & 3 & 4 & 5 & 6 & 7 & 8 & & & & \\
\hline 1972 & & & & & & 71.60 & 50.10 & 56.00 & 73.00 & 90.50 & 54.50 & 65.10 \\
\hline 1973 & 13.20 & 14.00 & 62.50 & 53.80 & 80.20 & 95.10 & 66.70 & 46.70 & 52.30 & 102,70 & 75.50 & 13.70 \\
\hline 1974 & 25.70 & 14.30 & 31.90 & 105.80 & 89.70 & 77.70 & 122.30 & 94.00 & 68.60 & 61.00 & 70.80 & 10.20 \\
\hline 1975 & 25.70 & 43.70 & 19.60 & 37.10 & 41.90 & 24.60 & 52.90 & 102.00 & 87.80 & 33.70 & 31.80 & 20.90 \\
\hline 1976 & 2,30 & 21.90 & 44.40 & 19.20 & 66.10 & 103.40 & 73.40 & 85.90 & 124.00 & 44.00 & 18.00 & 0.50 \\
\hline 1977 & 0.00 & 15.10 & 47.50 & 30.30 & 15.00 & 83.40 & 58.20 & 108.40 & 116.40 & 83.50 & 85.10 & 2.10 \\
\hline 1978 & 25,40 & 0,00 & 22.20 & 37.90 & 67.20 & 82.40 & 60.80 & 85.80 & 114,60 & 82.80 & 40.40 & 28.80 \\
\hline 1979 & 6.00 & 11.00 & 45.80 & 78.00 & 64.00 & 78.10 & 76.80 & 103.00 & 51.40 & 155.00 & 84.40 & 48.40 \\
\hline 1980 & 12.40 & 0.00 & 42.60 & 88.80 & 70.40 & 131.40 & 130.90 & 91.20 & 113.80 & 119.40 & 51.70 & 40.50 \\
\hline 1981 & 3.80 & 31.80 & 27.80 & 65.40 & 96.80 & 125.80 & 123,80 & 132.20 & 113.80 & 71,60 & 43.60 & 7.20 \\
\hline 1982 & 8.60 & 0.00 & 19.00 & 54.00 & 47.80 & 106.00 & 76.10 & 116.80 & 76.40 & 53.80 & 97.80 & 98.90 \\
\hline 1983 & 26.40 & 23.20 & 34.40 & 79.80 & 123.20 & 45.20 & 79.20 & 66.60 & 95.20 & 113.40 & 49.60 & 4.80 \\
\hline 1984 & 0.00 & 36.40 & 41.40 & 57.20 & 107.40 & 68.20 & 71.40 & 77.40 & 107.20 & 75.60 & 65.00 & 51.80 \\
\hline 1985 & 2.00 & 54.40 & 43.80 & 41.60 & 82.00 & 40.40 & 74.20 & 150.25 & 135.30 & 95.40 & 77.10 & 8.80 \\
\hline 1986 & 19.20 & 3.60 & 34.60 & 50.40 & 86.80 & 83.00 & 157.20 & 103,20 & 207.60 & 76.00 & 22.60 & 17.80 \\
\hline 1987 & 2.20 & 4.80 & 42.40 & 29.40 & 52.60 & 80.00 & 103.20 & 60.80 & 67.20 & 95.60 & 68.80 & 26.80 \\
\hline 1988 & 29.00 & 6.20 & 22.60 & 57.80 & 40.00 & 35.60 & 68.20 & 136.80 & 95.60 & 106.80 & 81.00 & 7.60 \\
\hline 1989 & 21.90 & 0.10 & 35.40 & 19.40 & 90.40 & 89.20 & 3.00 & 152.50 & 92.00 & 97.20 & 99.60 & 5.20 \\
\hline 1990 & 25.80 & 28.40 & 39.00 & 59.20 & 85.00 & 95.20 & 57.80 & 34,00 & 102.40 & 98.40 & 80.00 & 38.60 \\
\hline 1991 & 1.40 & 6.60 & 75.80 & 127.00 & 77.00 & 15.60 & 80.60 & 63.60 & 104.40 & 108.60 & 31.00 & 10.80 \\
\hline 1992 & 26.00 & 12.60 & 31.00 & 31.00 & 53.40 & 32.00 & 100.20 & 139.20 & 88.40 & 49.80 & 127.20 & 17.60 \\
\hline 1993 & 49.60 & 0.00 & 3.80 & 66.40 & 76.80 & 113.40 & 74.60 & 105.80 & 124.20 & 75.00 & 59.80 & 9.40 \\
\hline 1994 & 26.80 & 0,00 & 18.40 & 68.00 & 113.00 & 89.20 & 73.40 & 80.60 & 75.80 & 63.20 & 60.60 & 18.60 \\
\hline 1995 & 54.80 & 0.80 & 28.40 & 81.60 & 58.00 & 61.40 & 101.20 & 91.80 & 60.60 & 146.20 & 66.20 & 6.60 \\
\hline 1996 & 32.20 & 29.00 & 9.00 & 89.60 & 87.40 & 134.80 & 88.80 & 85.13 & 132.80 & 95.60 & 31.40 & 44.80 \\
\hline 1997 & 31.00 & 59.90 & 26.60 & 31.40 & 75.20 & 94.80 & 41.80 & 89.20 & 53.60 & 47.80 & 18.83 & 5.40 \\
\hline 1998 & 79.40 & 83.43 & 69.20 & 37.40 & 61.80 & 146.40 & 66.80 & 159.20 & 76.00 & 44.40 & 39.37 & 27.00 \\
\hline 1999 & 27.20 & 10.60 & 0.80 & 33.40 & 83.80 & 137.20 & 179.20 & 48.60 & 99.20 & 78.80 & 63.20 & 24.80 \\
\hline 2000 & 26.40 & 13.67 & 23.80 & 48.80 & 105.80 & 131.00 & 129.40 & 71.00 & 123.30 & 28.80 & 69.60 & 10.20 \\
\hline 2001 & 10.20 & 47.13 & 11.27 & 20,60 & 118.20 & 83.20 & 23.00 & 63.60 & 90.00 & 139.80 & 65.60 & 39.40 \\
\hline 2002 & 29.83 & 47.60 & 36.00 & 63.40 & 112.60 & 61,40 & 70.80 & 65.20 & 57.40 & 76.60 & 36.20 & 11.80 \\
\hline 2003 & 0.40 & 3.13 & 32.80 & 39.60 & 89.00 & 82.20 & 61.60 & 90.40 & 88.20 & 123.80 & 98.00 & 44.40 \\
\hline 2004 & 12.40 & 0.40 & 50.53 & 40.00 & 204.80 & 52.00 & 72.80 & 82.00 & 42.60 & 66.40 & 46.20 & 25.00 \\
\hline 2005 & 37.80 & 23.00 & 9.87 & 81.40 & 44.20 & 67.40 & 33.80 & 38.40 & 86.00 & 44.60 & 96.80 & 27.00 \\
\hline 2006 & 36.37 & 26.03 & 10.40 & 68.00 & 66.60 & 49.40 & 78.60 & 15.53 & 79.43 & 151.20 & 48.80 & 27.00 \\
\hline 2007 & 22.40 & 40.05 & 270.40 & 68.80 & 68.60 & 40.05 & 174.35 & 27.20 & 90.40 & 121.50 & 37.90 & 29.65 \\
\hline 2008 & 93.06 & 12,15 & 60.45 & 24.90 & 125.00 & 89.40 & 110.75 & 48.40 & 88.40 & 50.60 & 67.70 & 32.40 \\
\hline 2009 & 2.00 & 37.00 & 43.20 & 122,40 & 60.20 & 90.60 & 43.70 & 75.60 & 69.95 & 113.80 & 45.40 & 24.40 \\
\hline 2010 & 13.20 & 5.65 & 18.70 & 21.60 & 107.60 & & & & & & & \\
\hline Average & 22.69 & 20.20 & 39.14 & 56.05 & 81.46 & 81.26 & 81.88 & 85.37 & 92.77 & 86.39 & 60.71 & 24.58 \\
\hline
\end{tabular}


Shanty Bay

Verified Daily Rainfall arranged per month

\begin{tabular}{|c|c|c|c|c|c|c|c|c|c|c|c|c|}
\hline \multirow[b]{2}{*}{ Year/Month } & \multicolumn{12}{|c|}{ Total Rainfall (mm) } \\
\hline & 1 & 2 & 3 & 4 & 5 & 6 & 7 & 8 & 9 & 10 & 11 & 12 \\
\hline \multicolumn{13}{|l|}{1972} \\
\hline 1973 & & & & & & 76.30 & 87.80 & 39.30 & 38.90 & 113.60 & 79.00 & 14.40 \\
\hline 1974 & 23.60 & 14.40 & 31.60 & 94.90 & 98.90 & 96.70 & 55.30 & 161.20 & 47.70 & 66.30 & 75.70 & 7.60 \\
\hline 1975 & 10.40 & 39.60 & 28.90 & 41.40 & 42.10 & 31.60 & 71.70 & 111.90 & 79.80 & 44.00 & 39.70 & 33.60 \\
\hline 1976 & 1.30 & 17.30 & 45.20 & 44,50 & 71.40 & 32.00 & 123.50 & 67.10 & 173,30 & 52.30 & 14.30 & 5.30 \\
\hline 1977 & 0.00 & 8.40 & 49.20 & 29.60 & 35.20 & 88.90 & 63.50 & 140.20 & 133.00 & 70.20 & 71.40 & 16.20 \\
\hline 1978 & 23.40 & 0.00 & 36.60 & 38.20 & 60.00 & 62.60 & 32.80 & 87.00 & 93.40 & 61.80 & 30.80 & 23.20 \\
\hline 1979 & 8.60 & 6.80 & 36.00 & 58.20 & 66.80 & 70.30 & 36.00 & 83.40 & 39.80 & 135.20 & 83.40 & 51.80 \\
\hline 1980 & 7.20 & 2.00 & 37.60 & 86.60 & 36.80 & 103.20 & 171.60 & 51.20 & 99.20 & 86.00 & 43.40 & 39.60 \\
\hline 1981 & 2.40 & 27.60 & 22.60 & 46.00 & 97.60 & 71.80 & 58.60 & 159.80 & 80.40 & 66.00 & 47,80 & 5.00 \\
\hline 1982 & 8.80 & 0.20 & 25.20 & 42.80 & 50.20 & 123.20 & 78.00 & 103,40 & 62.80 & 44.60 & 109.20 & 85.00 \\
\hline 1983 & 18.20 & 32.40 & 29.80 & 70.40 & 93.80 & 28.20 & 62.80 & 63.60 & 84.40 & 82.40 & 62.60 & 6.40 \\
\hline 1984 & 0.00 & 32.00 & 35.80 & 60.20 & 89.40 & 49.80 & 52.20 & 91.00 & 106.80 & 51.80 & 63.40 & 35.60 \\
\hline 1985 & 1.60 & 55.00 & 42.00 & 25.80 & 88.40 & 33.20 & 83.40 & 144.20 & 89.40 & 78.80 & 76.40 & 7.60 \\
\hline 1986 & 15.20 & 11.40 & 34.80 & 54.80 & 92.60 & 105.00 & 70.00 & 128.00 & 263.20 & 66.80 & 15.60 & 25.40 \\
\hline 1987 & 1.40 & 5.40 & 39.60 & 29.60 & 52.00 & 134.00 & 111.60 & 66.00 & 78.20 & 76.80 & 60.80 & 25.00 \\
\hline 1988 & 24.60 & 4.20 & 15.80 & 49.80 & 54,40 & 48.80 & 68.60 & 99.80 & 113.00 & 85.80 & 75.00 & 13.60 \\
\hline 1989 & 19.80 & 0.20 & 20.00 & 21.20 & 89.40 & 102.60 & 12.20 & 69.90 & 72.40 & 94.20 & 106.60 & 5.60 \\
\hline 1990 & 15.60 & 28.60 & 56.60 & 43.40 & 87.20 & 106,00 & 62.80 & 20.80 & 99.20 & 104.00 & 71.20 & 41.60 \\
\hline 1991 & 1.40 & 5.20 & 61.60 & 129.20 & 72.40 & 38.60 & 107.40 & 43.40 & 56.00 & 66.20 & 44.40 & 8.20 \\
\hline 1992 & 14.80 & 15.40 & 27.40 & 45.00 & 58.20 & 28.80 & 87.00 & 100.20 & 93.80 & 58.00 & 106.00 & 15.00 \\
\hline 1993 & 33.80 & 0.20 & 0.60 & 69.80 & 76.40 & 99.00 & 75.80 & 75.40 & 121.00 & 72.40 & 65.80 & 5.60 \\
\hline 1994 & 19.40 & 0.00 & 13.00 & 58.00 & 103.20 & 53.60 & 53.60 & 70,20 & 89.40 & 58.40 & 48.40 & 16.20 \\
\hline 1995 & 53.00 & 1.00 & 25.20 & 72.20 & 58.00 & 128.60 & 115.80 & 133.80 & 71.60 & 127.20 & 61.20 & 4.20 \\
\hline 1996 & 36.00 & 28.40 & 6.80 & 99.60 & 79.80 & 144.40 & 108.20 & 86.80 & 152.80 & 88.20 & 32.60 & 42,40 \\
\hline 1997 & 18.40 & 61.00 & 16.80 & 24,40 & 74.00 & 97.40 & 25.00 & 87.40 & 44.50 & 42,20 & 30.80 & 14.40 \\
\hline 1998 & 77.20 & 19.40 & 66.60 & 47.00 & 35.00 & 134.80 & 45.20 & 136.60 & 94.40 & 35.20 & 38.60 & 32.80 \\
\hline 1999 & 26.60 & 15.40 & 1.20 & 26.00 & 55.40 & 118.80 & 92.40 & 65.20 & 94.80 & 62.80 & 83.20 & 26.40 \\
\hline 2000 & 22.40 & 16.00 & 29.60 & 46,40 & 117,40 & 179.00 & 54,40 & 99.40 & 108,40 & 24.80 & 68.40 & 9.60 \\
\hline 2001 & 10.40 & 40.20 & 9.20 & 31.20 & 100.40 & 82.40 & 29.20 & 87.40 & 86.20 & 126.40 & 63,00 & 39.20 \\
\hline 2002 & 5.80 & 37.80 & 24.80 & 81.40 & 139.60 & 77.60 & 68.20 & 104.20 & 53.60 & 64.00 & 32.00 & 8.20 \\
\hline 2003 & 0.00 & 16.20 & 32.20 & 28.80 & 73.00 & 45.40 & 61.00 & 68.80 & 65.20 & 103.60 & 84.00 & 39.40 \\
\hline 2004 & 10.60 & 0.00 & 76.80 & 35.80 & 148.40 & 44.00 & 124.80 & 48.00 & 37.40 & 61.60 & 57.00 & 28.00 \\
\hline 2005 & 29.60 & 16.00 & 9.00 & 73.40 & 26.80 & 142.40 & 50.40 & 65.20 & 78.60 & 44.00 & 8100 & 28.40 \\
\hline 2006 & 44.00 & 22,80 & 55.80 & 80.60 & 52.20 & 85.80 & 143.80 & 22.20 & 100.20 & 129.20 & 91,60 & 39.20 \\
\hline 2007 & 18.70 & 59.10 & 12.40 & 66.10 & 50.60 & 15.43 & 86.33 & 48.90 & 58.40 & 128.63 & 47.50 & 40.00 \\
\hline 2008 & 48.00 & 13.70 & 42.65 & 41.50 & 102.00 & 73.00 & 101.50 & 78.10 & 105.00 & 41.40 & 60.60 & 29.00 \\
\hline 2009 & 0.60 & 36.10 & 38.90 & 105.10 & 78.70 & 95.00 & 124.80 & 58.70 & 42.10 & 86.00 & 38.70 & 29.60 \\
\hline 2010 & $\quad 10.50$ & 0.10 & 30.50 & 25.70 & 99.20 & & & & & & & \\
\hline Average & 17.93 & 18.64 & 31.58 & 54.72 & 75.86 & 84.01 & 77.22 & 85.61 & 89.42 & 75.70 & 61.11 & 24.28 \\
\hline
\end{tabular}


Udora

Verified Daily Rainfall arranged per month

Total Rainfall (mm)

\begin{tabular}{|c|c|c|c|c|c|c|c|c|c|c|c|c|}
\hline \multirow[b]{2}{*}{ Year/Month } & \multicolumn{12}{|c|}{ 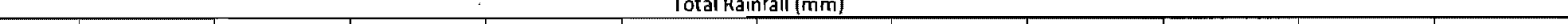 } \\
\hline & 1 & 2 & 3 & 4 & 5 & 6 & 7 & 8 & 9 & 10 & 11 & 12 \\
\hline 1990 & & & & & & 108.8 & 68.5 & 36.9 & 36.9 & 109.7 & 62.9 & 53.3 \\
\hline 1991 & 12.6 & 9.4 & 70.8 & 127 & 48 & 35.1 & 64.1 & 77.9 & 77.9 & 67.7 & 44.8 & 11.6 \\
\hline 1992 & 7.4 & 9.7 & 25.3 & 53 & 50.2 & 43.6 & 81.6 & 131.6 & 131.6 & 52 & 75.3 & 14.2 \\
\hline 1993 & 39.7 & 0 & 4 & 56.1 & 65 & 95.4 & 66.4 & 81.8 & 81.8 & 59.8 & 61 & 11.4 \\
\hline 1994 & 15 & 0 & 11.8 & 68.2 & 124.2 & 30.8 & 95.6 & 43.3 & 43.3 & 40.7 & 44.4 & 22.8 \\
\hline 1995 & 89.3 & 1 & 17.2 & 63.8 & 69.4 & 114.5 & 124.4 & 99.6 & 99.6 & 138.7 & 103.5 & 3.6 \\
\hline 1996 & 45.9 & 24 & 4.8 & 78 & 65.2 & 132.8 & 100.2 & 100.4 & 100.4 & 57 & 19.4 & 47.4 \\
\hline 1997 & 18.8 & 66.3 & 23.1 & 22.8 & 74.6 & 111 & 40.8 & 74.7 & 74.7 & 51 & 43.1 & 9 \\
\hline 1998 & 70.6 & 31.6 & 58.3 & 60,6 & 32 & 194.7 & 60.4 & 117,6 & 117.6 & 36.2 & 28 & 32.8 \\
\hline 1999 & 23.4 & 17 & 3.4 & 34.6 & 79.8 & 135.2 & 105.8 & 62.6 & 62.6 & 77.8 & 101.4 & 24.8 \\
\hline 2000 & 21.2 & 7 & 22.6 & 35.4 & 138.3 & 254.9 & 46.6 & 83.6 & 83.6 & 24.8 & 69.4 & 7.6 \\
\hline 2001 & 4 & 30.8 & 14.6 & 27.4 & 68 & 66 & 47.8 & 50.9 & 50.9 & 146.4 & 85.6 & 39.6 \\
\hline 2002 & 1 & 22.7 & 31.2 & 89.3 & 202.8 & 137.2 & 101.6 & 55.4 & 55.4 & 61.6 & 41,4 & 2 \\
\hline 2003 & 0 & 11.2 & 30.6 & 36.8 & 89.4 & 106.4 & 49.4 & 106.6 & 106.6 & 78.8 & 103,4 & 48.4 \\
\hline 2004 & 4.8 & 0 & 50.2 & 54,4 & 111.4 & 53.2 & 179.6 & 40.4 & 40.4 & 58.2 & 62 & 37.6 \\
\hline 2005 & 15,8 & 15.8 & 4 & 71.2 & 18.8 & 123 & 41,4 & 63.5 & 63.5 & 44 & 69.6 & 28.4 \\
\hline 2006 & 41 & 32.6 & 41.8 & 67.4 & 91.6 & 69.2 & 195 & 30.2 & 30.2 & 108.3 & 65.4 & 46.3 \\
\hline 2007 & 23.2 & 2.5 & 10.6 & 46.6 & 54 & 53.8 & 40.5 & 40 & 40 & 87.3 & 47.6 & 17.6 \\
\hline 2008 & 24.4 & 16.4 & 31.8 & 36.4 & 107.4 & 125.2 & 105.6 & 140.6 & 140.6 & 35.2 & 55 & 48.2 \\
\hline 2009 & 0 & 42.3 & 44.8 & 115.2 & 96.2 & 76.2 & 94 & 82.6 & 82.6 & 69.4 & 46.6 & 20.2 \\
\hline 2010 & 15.2 & 0 & 50 & 26.8 & 85.8 & & & & & & & \\
\hline Average & 23.67 & 17.02 & 27.55 & 58.55 & 83.61 & 103.35 & 85.47 & 76.01 & 76.01 & 70.23 & 61.49 & 26.34 \\
\hline
\end{tabular}




\section{Appendix D}

Verified Daily Rainfall Arranged Per Season 
Barrie

Verified Daily Rainfall arranged per Season

\begin{tabular}{|c|c|c|c|c|}
\hline \multirow[t]{2}{*}{ YEAR } & \multicolumn{4}{|c|}{ Total Rainfall (mm) } \\
\hline & Winter (Dec, Jan, Feb) & Spring (Mar, Apr, May) & Summer (Jun, Jul, Aug) & Fall (Sep, Oct, Nov) \\
\hline \multicolumn{5}{|l|}{1972.1973} \\
\hline \multicolumn{5}{|l|}{$1973 \cdot 1974$} \\
\hline \multicolumn{5}{|l|}{$1974-1975$} \\
\hline \multicolumn{5}{|l|}{$1975-1976$} \\
\hline \multicolumn{5}{|l|}{$1976-1977$} \\
\hline $1977-1978$ & & & 209.8 & 193.0 \\
\hline $1978-1979$ & 17.7 & 173.8 & 179.0 & 276.5 \\
\hline $1979-1980$ & 55.3 & 154.2 & 298.1 & 197.3 \\
\hline $1980-1981$ & 54.7 & 163.6 & 255.6 & 218.7 \\
\hline $1981-1982$ & 16.8 & 119.1 & 286.8 & 207.6 \\
\hline $1982-1983$ & 104.4 & 204.2 & 146.8 & 227.8 \\
\hline $1983-1984$ & 21.0 & 175.4 & 169.2 & 222.2 \\
\hline $1984 \cdot 1985$ & 85.8 & 164.8 & 296.2 & 218.9 \\
\hline $1985-1986$ & 18.0 & 183.2 & 298.0 & 400.8 \\
\hline $1986-1987$ & 19.0 & 145.0 & 351.8 & 217.6 \\
\hline $1987-1988$ & 47.4 & 149.8 & 206.5 & 299.2 \\
\hline $1988-1989$ & 40.0 & 159.8 & 188.4 & 242.6 \\
\hline $1989-1990$ & 35.0 & 191.8 & 182.6 & 294.8 \\
\hline $1990-1991$ & 37.2 & 253.6 & 185.0 & 166.8 \\
\hline 1991 - 1992 & 24.6 & 130.4 & 225.4 & 256.2 \\
\hline $1992-1993$ & 36.2 & 147.4 & 241.1 & 237.3 \\
\hline $1993-1994$ & 35.1 & 176.6 & 181.6 & 203.6 \\
\hline $1994-1995$ & 77.4 & 152.9 & 403.3 & 270.6 \\
\hline $1995-1996$ & 56.4 & 191.4 & 288.0 & 302.8 \\
\hline $1996-1997$ & 111.8 & 146.4 & 213.1 & 143.3 \\
\hline $1997-1998$ & 91.2 & 158.9 & 279.3 & 180.2 \\
\hline $1998-1999$ & 61.0 & 85.2 & 321.4 & 247.1 \\
\hline $1999-2000$ & .62 .5 & $\cdots \quad \cdots \quad 228.8$ & 370.5 & 189.3 \\
\hline $2000-2001$ & 50.4 & 145.5 & 188.7 & 304.9 \\
\hline $2001-2002$ & 92.8 & 239.2 & 220.6 & 148.6 \\
\hline $2002-2003$ & 8.5 & 146.3 & 322.6 & 292.6 \\
\hline $2003-2004$ & 55.8 & 257.8 & 234.9 & 156.1 \\
\hline $2004-2005$ & 58.4 & 120.6 & 234.5 & 207.1 \\
\hline $2005-2006$ & 87.9 & 153.8 & & \\
\hline \multicolumn{5}{|l|}{$2006 \cdot 2007$} \\
\hline \multicolumn{5}{|l|}{$2007-2008$} \\
\hline \multicolumn{5}{|l|}{$2008-2009$} \\
\hline \multicolumn{5}{|l|}{$2009 \cdot 2010$} \\
\hline Average All & 52.2 & 168.6 & 249.2 & 233.0 \\
\hline
\end{tabular}


Coldwater Warminster

Verified Daily Rainfall arranged per Season

\begin{tabular}{|c|c|c|c|c|}
\hline \multirow[t]{2}{*}{ YEAR } & \multicolumn{4}{|c|}{ Total Rainfall (mm) } \\
\hline & Winter (Dec, Jan, Feb) & Spring (Mar, Apr, May) & Summer (Jun, Jul, Aug) & Fall (Sep, Oct, Nov) \\
\hline 1972 & & & 177.7 & 218 \\
\hline $1972-1973$ & 92.3 & 196.5 & 208.5 & 230.5 \\
\hline $1973-1974$ & 53.7 & 227.4 & 294.0 & 200.4 \\
\hline $1974-1975$ & 79.6 & 98.6 & 179.5 & 153.3 \\
\hline $1975-1976$ & 45.1 & 129.7 & 262.7 & 186.0 \\
\hline $1976-1977$ & 15.6 & 92.8 & 250.0 & 285.0 \\
\hline $1977-1978$ & 27.5 & 127.3 & 229.0 & 237.8 \\
\hline $1978-1979$ & 45.8 & 187.8 & 257.9 & 290.8 \\
\hline $1979-1980$ & 60.8 & 201.8 & 353.5 & 284.9 \\
\hline $1980-1981$ & 76.1 & 190.0 & 381.8 & 229.0 \\
\hline $1981-1982$ & 15.8 & 120.8 & 298.9 & 228.0 \\
\hline $1982-1983$ & 148.5 & 237.4 & 191.0 & 258.2 \\
\hline $1983-1984$ & 41.2 & 206.0 & 217.0 & 247.8 \\
\hline $1984-1985$ & 108.2 & 167.4 & 264.9 & 307.8 \\
\hline $1985-1986$ & 31.6 & 171.8 & 343.4 & 306.2 \\
\hline $1986-1987$ & 24.8 & 124.4 & 244.0 & 231.6 \\
\hline $1987-1988$ & 62.0 & 120.4 & 240.6 & 283.4 \\
\hline $1988-1989$ & 29.6 & 145.2 & 244.7 & 288.8 \\
\hline $1989-1990$ & 59.4 & 183.2 & 187.0 & 280.8 \\
\hline $1990-1991$ & 46.6 & 279.8 & 159.8 & 244.0 \\
\hline $1991-1992$ & 49.4 & 115.4 & 271.4 & 265.4 \\
\hline $1992-1993$ & 67.2 & 147.0 & 293.8 & 259.0 \\
\hline $1993-1994$ & 36.2 & 199.4 & 243.2 & 199.6 \\
\hline $1994-1995$ & 74.2 & 168.0 & 254.4 & 273.0 \\
\hline $1995-1996$ & 67.8 & 186.0 & 308.7 & 259.8 \\
\hline $1996-1997$ & 135.7 & 133.2 & 225.8 & 120.2 \\
\hline $1997-1998$ & 168.2 & 168.4 & 372.4 & 159.8 \\
\hline $1998-1999$ & 64.8 & 118.0 & 365.0 & $\begin{array}{r}241.2 \\
\end{array}$ \\
\hline $1999-2000$ & 64.9 & 178.4 & 331.4 & 221.7 \\
\hline $2000-2001$ & 67.5 & 150.1 & 169.8 & 295.4 \\
\hline $2001-2002$ & 116.8 & 212.0 & 197.4 & 170.2 \\
\hline $2002-2003$ & 15.3 & 161.4 & 234.2 & 310.0 \\
\hline $2003-2004$ & 57.2 & 295.3 & 206.8 & 155.2 \\
\hline $2004-2005$ & 85.8 & 135.5 & 139.6 & 227.4 \\
\hline $2005-2006$ & 89.4 & 145.0 & 143.5 & 279.4 \\
\hline $2006-2007$ & 89.5 & 407.8 & 241.6 & 249.8 \\
\hline $2007-2008$ & 134.9 & 210.4 & 248.6 & 206.7 \\
\hline $2008-2009$ & 71.4 & 225.8 & 209.9 & 229.2 \\
\hline $2009-2010$ & 43.3 & 147.9 & & \\
\hline Average All & 67.5 & 176.7 & 248.5 & 239.9 \\
\hline
\end{tabular}


Shanty Bay

Verified Daly Rainfall arranged per Season

\begin{tabular}{|c|c|c|c|c|}
\hline \multirow[t]{2}{*}{ YEAR } & \multicolumn{4}{|c|}{ Total Rainfall (mm) } \\
\hline & Winter $(\mathrm{Dec}$, Jan, Feb $)$ & Spring (Mar, Apr, May) & Summer (Jun, Jul, Aug) & Fall (Sep, Oct, Nov) \\
\hline $1972-1973$ & & & 203.4 & 166.0 \\
\hline $1973-1974$ & 52.4 & 225.4 & 313.2 & 189.7 \\
\hline $1974-1975$ & 57.6 & 112.4 & 215.2 & 163.5 \\
\hline $1975-1976$ & 52.2 & 161.1 & 282.6 & 239.9 \\
\hline $1976-1977$ & 13.7 & 114.0 & 292.6 & 274.6 \\
\hline $1977-1978$ & 39.6 & 134.8 & 182.4 & 186.0 \\
\hline $1978-1979$ & 38.6 & 161.0 & 189.7 & 258.4 \\
\hline $1979-1980$ & 61.0 & 161.0 & 326.0 & 228.6 \\
\hline $1980-1981$ & 69.6 & 166.2 & 290.2 & 194.2 \\
\hline $1981-1982$ & 14.0 & 118.2 & 304.6 & 216.6 \\
\hline $1982-1983$ & 135.6 & 194.0 & 154.6 & 229.4 \\
\hline $1983-1984$ & 38.4 & 185.4 & 193.0 & 222.0 \\
\hline $1984-1985$ & 92.2 & 156.2 & 260.8 & 244.6 \\
\hline $1985-1986$ & 34.2 & 182.2 & 303.0 & 345.6 \\
\hline $1986-1987$ & 32.2 & 121.2 & 311.6 & 215.8 \\
\hline $1987-1988$ & 53.8 & 120.0 & 217.2 & 273.8 \\
\hline $1988-1989$ & 33.6 & 130.6 & 184.7 & 273.2 \\
\hline $1989-1990$ & 49.8 & 187.2 & 189.6 & 274.4 \\
\hline $1990-1991$ & 48.2 & 263.2 & 189.4 & 166.6 \\
\hline $1991-1992$ & 38.4 & 130.6 & 216.0 & 257.8 \\
\hline $1992-1993$ & 49.0 & 146.8 & 250.2 & 259.2 \\
\hline $1993-1994$ & 25.0 & 174.2 & 177.4 & 196.2 \\
\hline $1994-1995$ & 70.2 & 155.4 & 378.2 & 260.0 \\
\hline $1995-1996$ & 68.6 & 186.2 & 339.4 & 273.6 \\
\hline $1996-1997$ & 121.8 & 115.2 & 209.8 & 117.6 \\
\hline $1997-1998$ & 111.0 & 148.6 & 316.6 & 168.2 \\
\hline $1998-1999$ & 74.8 & 82.6 & 276.4 & 240.8 \\
\hline $1999-2000 \cdots$ & 64.8 & 193.4 & 332.8 & 201.6 \\
\hline $2000-2001$ & 60.2 & 140.8 & 199.0 & 275.6 \\
\hline $2001-2002$ & 82.8 & 245.8 & 250.0 & 149.6 \\
\hline $2002-2003$ & 24.4 & 134.0 & 175.2 & 252.8 \\
\hline $2003-2004$ & 50.0 & 261.0 & 216.8 & 156.0 \\
\hline $2004-2005$ & 73.6 & 109.2 & 258.0 & 203.6 \\
\hline $2005-2006$ & 95.2 & 188.6 & 251.8 & 321.0 \\
\hline $2006-2007$ & 117.0 & 129.1 & 150.7 & 234.5 \\
\hline $2007-2008$ & 101.7 & 186.2 & 252.6 & 207.0 \\
\hline $2008-2009$ & 65.7 & 222.7 & 278.5 & 166.8 \\
\hline $2009 \cdot 2010$ & 40.2 & 155.4 & & \\
\hline Average All & 60.8 & 162.2 & 246.8 & 224.5 \\
\hline
\end{tabular}


Udora

Verified Daily Rainfall arranged per Season

\begin{tabular}{|c|c|c|c|c|}
\hline \multirow[t]{2}{*}{ YEAR } & \multicolumn{4}{|c|}{ Total Rainfall (mm) } \\
\hline & Winter (Dec, Jan, Feb) & Spring (Mar, Apr, May) & Summer (Jun, Jul, Aug) & Fall (Sep, Oct, Nov) \\
\hline $1972-1973$ & & & & \\
\hline $1973-1974$ & & & & \\
\hline $1974-1975$ & & & & \\
\hline $1975-1976$ & & & & \\
\hline $1976-1977$ & & . & & \\
\hline $1977-1978$ & & & & \\
\hline $1978-1979$ & & & & \\
\hline $1979-1980$ & & & & \\
\hline $1980-1981$ & & & & \\
\hline $1981-1982$ & & & & \\
\hline $1982-1983$ & & & & \\
\hline $1983-1984$ & & & & \\
\hline $1984-1985$ & & & & \\
\hline $1985-1986$ & & & & \\
\hline $1986-1987$ & & & & \\
\hline $1987-1988$ & & & & \\
\hline $1988-1989$ & & & & \\
\hline $1989-1990$ & & & 214.2 & 209.5 \\
\hline $1990-1991$ & 75.3 & 245.8 & 177.1 & 190.4 \\
\hline $1991-1992$ & 28.7 & 128.5 & 256.8 & 258.9 \\
\hline $1992-1993$ & 53.9 & 125.1 & 243.6 & 202.6 \\
\hline $1993-1994$ & 26.4 & 204.2 & 169.7 & 128.4 \\
\hline $1994-1995$ & 113.1 & 150.4 & 338.5 & 341.8 \\
\hline $1995-1996$ & 73.5 & 148.0 & 333.4 & 176.8 \\
\hline $1996-1997$ & 132.5 & 120.5 & 226.5 & 168.8 \\
\hline $1997-1998$ & 111.2 & 150.9 & 372.7 & 181.8 \\
\hline $1998-1999$ & 73.2 & 117.8 & 303.6 & 241.8 \\
\hline $1999-2000$ & .53 .0 & 196.3 & 385.1 & 177.8 \\
\hline $2000-2001$ & 42.4 & 110.0 & 164.7 & 282.9 \\
\hline $2001-2002$ & 63.3 & 323.3 & 294.2 & 158.4 \\
\hline $2002-2003$ & 13.2 & 156.8 & 262.4 & 288.8 \\
\hline $2003-2004$ & 53.2 & 216.0 & 273.2 & 160.6 \\
\hline $2004-2005$ & 69.2 & 94.0 & 227.9 & 177.1 \\
\hline $2005-2006$ & 102.0 & 200.8 & 294.4 & 203.9 \\
\hline $2006-2007$ & 72.0 & 111.2 & 134.3 & 174.9 \\
\hline $2007-2008$ & 58.4 & 175.6 & 371.4 & 230.8 \\
\hline $2008-2009$ & 90.5 & 256.2 & 252.8 & 198.6 \\
\hline $2009-2010$ & 35.4 & 162.6 & & \\
\hline Average All & 67.0 & 169.7 & 264.8 & 207.7 \\
\hline
\end{tabular}




\section{References}

1. Lake Simcoe Region Conservation Authority (2009) Report on Phosphorous Loads to Lake Simcoe 2004-2007.

2. Natural Resources Canada website hitp://atlas.nrcan.gc.ca/site/english/maps/climatechange/1

3. IPCC Fourth Assessment Report (2007) Working Group I Report "The Physical Science Basis" http://www.ipcc.ch/ipccreports/art-wg1.htm

4. Ontario Ministry of Natural Resources, Applied Research and Development Branch (2007) Climate change projections for Ontario: practical information for policymakers and planners.

http://www.mnr.gov.on.ca/stdprodconsume/groups/lr/@mnr/@ofri/documents/do cument/mnr_e005587.pdf

5. C. J. Wiesner (1970) Hydrometeorology Chapman and Hall Ltd.

6. National Meteorological Library and Archive, Met Office UK (2007) Fact Sheet 3 Water in the Atmosphere

7. A.T. Hjelmnfelt, Jr. and J.J. Cassidy (1975) Hydrology for Engineers and Planners ( $1^{\text {st }}$ edition) lowa State University Press

8. Barry J Adams (2000) Urban Stormwater Management Planning with Analytical Probabilistic Models John Wiley and Sons Inc.

9. Greater Moncton Sewerage Commission (2003) Integrated Long term sustainable wastewater management strategy, combined Sewer Overflow Stratergy Report

10. Richard H. McCuen (1998) Hydrologic Analysis and Design ( $2^{\text {nd }}$ Edition) Prentice Hall International

11. http://www.nicholas.duke.edu/people/faculty/katul/ENV234_Lecture_3.pdf

12. Ramesh S.V. Teegavarapua, V. Chandramouli (2005) Improved weighting methods, deterministic and stochastic data-driven models for estimation of missing precipitation records Journal of Hydrology 312 pages 191-206

13. http://www.kriging.com/whatiskriging.html

14. http://www.geog.ucsb.edu/ ta176/g176b/lab5/kriging_spatial_analyst.pdf

15. R. Romero, J.A. Guijarro, C. Ramis, S. Alonso (1998) A 30 year (1964-1993) Daily Rainfall Database for the Spanish Mediterranean Regions: First Exploratory Study International Journal of Climatology volume 18 pages $54 \mid-560$ 
16. Andy Y. Kwarteng, Atsu S. Dorvlo, G.T. Vijay Kumar (2009) Analysis of a 27-year rainfall data (1997-2003) in the Sultanate of Oman International Journal of Climatology volume 29 pages $605-617$

17. B. Wouter, R. Celleri, P. Williams, B.D.Bievre, G. Wyseure (2006) Spatial and temporal rainfall variability in mountainous areas: A case study from south Ecuadorian Andes Journal of Hydrology volume 329 pages $413-421$

18. A. S. Bazaraa, S. Ahmed (1991) Rainfall Characterization in arid areas Engineering Journal of Qatar University volume 4, pages 35-50

19. N. Welner (2009) Rainfall trends in the KwaZulu-Natal Drakensberg region of South Africa during the twentieth Century International Joumal of Climatology volume 29 pages 1634-1641

20. J. Olsson, J. Niemczynowicz (1996) Multifractal analysis of daily spatial rainfall distributions Journal of Hydrology volume 187 pages 29-43

21. M. Cislaghi, C. De Michele, A Ghezzi, R. Rosso (2005) Statistical assessment of trends and oscillations in rainfall dynamics: Analysis of long daily Italian series Atmospheric Research volume 77 pages $188-202$

22. R. L. Presti, E. Barca, G. Passarella (2010) A methodology for treating missing data applied to daily rainfall data in the Candelaro River Basin (Italy) Environ Monit Assess volume 160 pages $1-22$

23. http://www.srh.noaa.gov/images/sjtevents/1936Rainfallmap.jpg

24. Finnish Meteorological Institute, Air Quality Report No. 31 (2002) Detecting Trends of Annual Values of Atmospheric Pollutants by the Mann-Kendall Test and Sen's Slope Estimates - An Excel Template Applications MAKESENS ilmatieteenlaitos.fi/kuvat/MAKESENS_MANUAL.pdf

25. U.S. Army Corps of Engineers (2005) OU-1 Annual Groundwater Monitoring Report- Former Ford Ord, California http://dubaobien.vn/dhkhtn/stores/files/0907_Tailieu_CuaLo/TLTK/MANNKENDALL\%20ANALYSIS.pdf 